In cooperation with the San Antonio Water System

Quality of Groundwater at and near an Aquifer Storage and Recovery Site, Bexar, Atascosa, and Wilson Counties, Texas, June 2004-August 2008

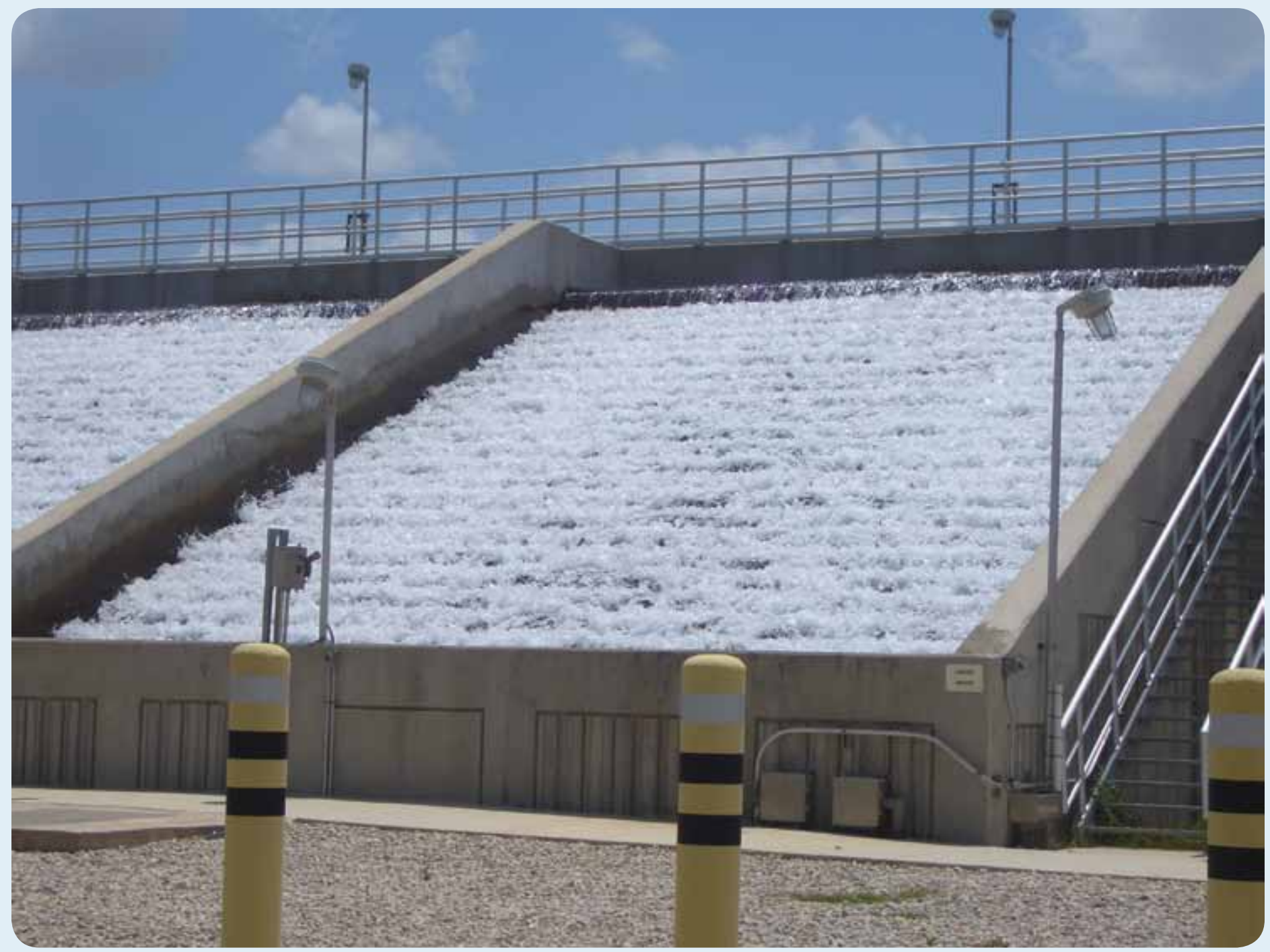

Scientific Investigations Report 2010-5061 
Front cover: Cascading aerator at aquifer storage and recovery plant (photograph by Cassi L. Otero).

Back cover:

Top: Edwards production well artesia pump station (photograph by Brian L. Petri, September 2007).

Botttom: Flooding on Galvan Creek (photograph by Michael B. Nyman, June 2005). 


\section{Quality of Groundwater at and near an Aquifer Storage and Recovery Site, Bexar, Atascosa, and Wilson Counties, Texas, June 2004-August 2008}

By Cassi L. Otero and Brian L. Petri

In cooperation with the San Antonio Water System

Scientific Investigations Report 2010-5061 


\section{U.S. Department of the Interior \\ KEN SALAZAR, Secretary \\ U.S. Geological Survey \\ Marcia K. McNutt, Director}

U.S. Geological Survey, Reston, Virginia: 2010

This and other USGS information products are available at http://store.usgs.gov/
U.S. Geological Survey
Box 25286, Denver Federal Center
Denver, CO 80225
To learn about the USGS and its information products visit http://www.usgs.gov/
1-888-ASK-USGS

Any use of trade, product, or firm names is for descriptive purposes only and does not imply endorsement by the U.S. Government.

Although this report is in the public domain, permission must be secured from the individual copyright owners to reproduce any copyrighted materials contained within this report.

Suggested citation:

Otero, C.L., and Petri, B.L., 2010, Quality of groundwater at and near an aquifer storage and recovery site, Bexar, Atascosa, and Wilson Counties, Texas, June 2004-August 2008: U.S. Geological Scientific Investigations Report 2010-5061, $34 \mathrm{p}$. 


\section{Acknowledgments}

The authors thank McCoy, Oak Hills, Picosa, Sutherland Springs, and Three Oaks Water Supply Corporations; the Cities of Floresville, Jourdanton, Pleasanton, and Poteet; and landowner Tom Ray for granting access to wells sampled for this report. 


\section{Contents}

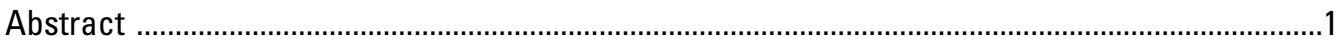

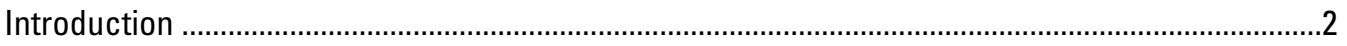

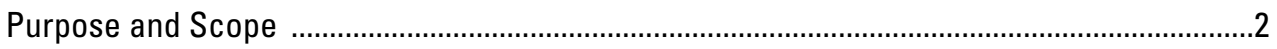

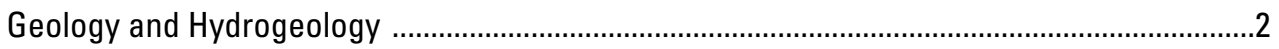

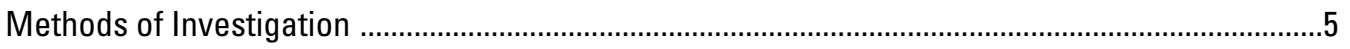

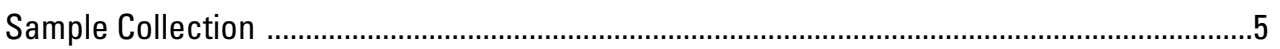

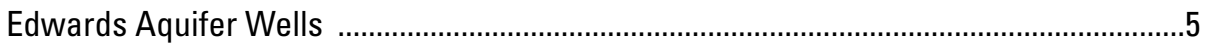

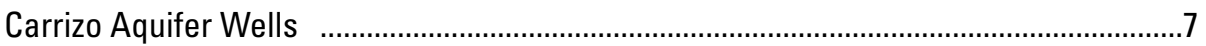

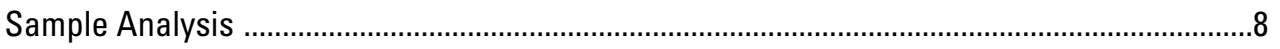

Water-Chemistry and Isotope Analysis .............................................................................

Quality Control and Quality Assurance of Water-Quality Samples ........................................

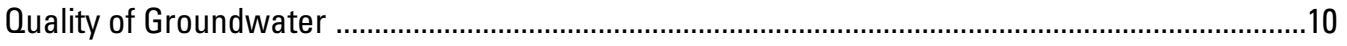

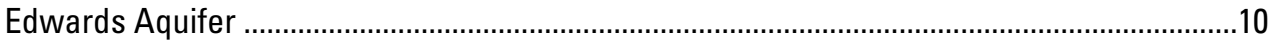

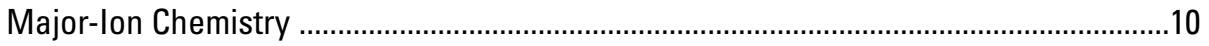

Trace-Element Chemistry ........................................................................................10

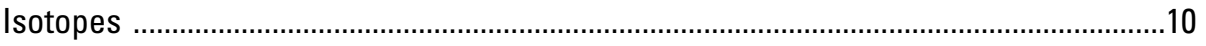

Pre-Injection Carrizo Aquifer ............................................................................................14

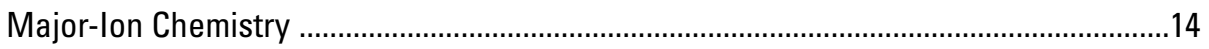

Trace-Element Chemistry ..........................................................................................

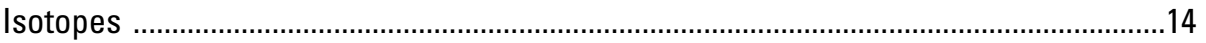

Post-Injection Carrizo Aquifer ............................................................................................

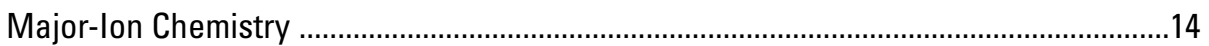

Trace-Element Chemistry ............................................................................................18

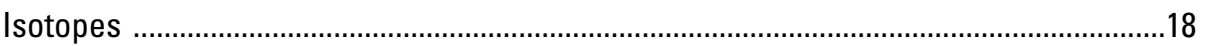

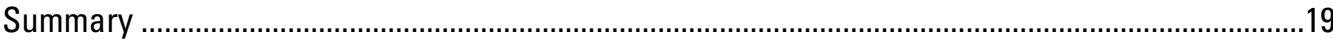

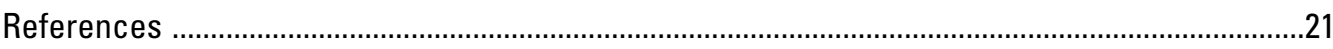

Appendixes

1. Chemical and isotope data from wells sampled at and near an aquifer storage and recovery site, Bexar, Atascosa, and Wilson Counties, Texas, 2004-08

2. Relative percent difference for duplicate chemical and isotope data from wells sampled at and near an aquifer storage and recovery site, Atascosa and Wilson Counties, Texas, 2004-08

3. Chemical data in stormwater samples from two surface-water sites near an aquifer storage and recovery site, Atascosa County, Texas, 2004-05

4. Bacteria data in stormwater samples from two surface-water sites near an aquifer storage and recovery site, Atascosa County, Texas, 2004-05

\section{Figures}

\section{1-2. Maps showing:}

1. Location of an aquifer storage and recovery site and data-collection sites, Bexar, Atascosa, and Wilson Counties, Texas 
2. Outcrops and subcrops of the Carrizo-Wilcox aquifer and Edwards aquifer in Texas, and generalized hydrogeologic section of the water-yielding Carrizo Sand and Wilcox Group and other near-surface formations at an aquifer storage and recovery site, Bexar, Atascosa, and Wilson Counties

3-5. Graphs showing:

3. Relation between delta oxygen-18 and delta deuterium for 25 wells screened or open in the Carrizo and Edwards aquifers, Bexar, Atascosa, and Wilson Counties, Texas, 2004-08

4. Relation between strontium-87/strontium- 86 and boron-11/boron- 10 for 24 wells screened or open in the Carrizo and Edwards aquifers, Bexar, Atascosa, and Wilson Counties, Texas, 2004-08

5. Relation between radium-226 and radium-228 for 25 wells screened or open in the Carrizo and Edwards aquifers, Bexar, Atascosa, and Wilson Counties, Texas, 2004-08

6. Diagram showing concentrations of selected cations and anions for wells screened in the Carrizo aquifer in northeastern Atascosa and western Wilson Counties, Texas (A) 2004 Carrizo samples, (B) 2005 Carrizo samples, and (C) 2008 Carrizo samples

7. Trilinear diagram showing composition of Edwards aquifer water injected at an aquifer storage and recovery (ASR) site, May 2005, and composition of water recovered from ASR site, July 2008, southern Bexar County, Texas

\section{Tables}

1. Wells from which water samples were collected at and near an aquifer storage and recovery site, Bexar, Atascosa, and Wilson Counties, Texas, 2004-08

2. Well-sampling schedule by aquifer for samples collected at and near an aquifer storage and recovery site, Bexar, Atascosa, and Wilson Counties, Texas, 2004-08 ......7

3. Dissolved iron and dissolved manganese concentrations from 11 wells sampled in northeastern Atascosa and western Wilson Counties, Texas, 2004-08, with percent difference between 2005 or 2008 concentrations and 2004 concentration 


\section{Conversion Factors, Datum, Water-Quality Units, and Isotope Unit Explanations}

\section{Inch/Pound to SI}

\begin{tabular}{lcl}
\hline & Multiply & \multicolumn{1}{c}{ Bo obtain } \\
\hline inch (in.) & Length & \\
foot (ft) & 25.4 & millimeter $(\mathrm{mm})$ \\
mile (mi) & 0.3048 & meter $(\mathrm{m})$ \\
\hline & 1.609 & kilometer $(\mathrm{km})$ \\
\hline acre & Area & \\
square mile $\left(\mathrm{mi}^{2}\right)$ & 0.4047 & hectare $(\mathrm{ha})$ \\
\hline & 2.590 & square kilometer $\left(\mathrm{km}^{2}\right)$ \\
\hline gallon per minute $(\mathrm{gal} / \mathrm{min})$ & Flow rate & liter per second $(\mathrm{L} / \mathrm{s})$ \\
million gallons per day $(\mathrm{Mgal} / \mathrm{d})$ & 0.06309 & cubic meter per $\mathrm{second}\left(\mathrm{m}^{3} / \mathrm{s}\right)$ \\
\hline & 0.04381 & \\
\hline foot squared per day $\left(\mathrm{ft}^{2} / \mathrm{d}\right)$ & Transmissivity & meter squared $\mathrm{per} \mathrm{day}\left(\mathrm{m}^{2} / \mathrm{d}\right)$ \\
\hline
\end{tabular}

Temperature in degrees Celsius $\left({ }^{\circ} \mathrm{C}\right)$ may be converted to degrees Fahrenheit $\left({ }^{\circ} \mathrm{F}\right)$ as follows:

$$
{ }^{\circ} \mathrm{F}=\left(1.8 \times^{\circ} \mathrm{C}\right)+32
$$

\section{Datum}

Horizontal coordinate information is referenced to the North American Datum of 1983 (NAD 83).

\section{Water-Quality Units}

Concentrations are reported in metric units. Chemical concentrations are reported in milligrams per liter (mg/L), micrograms per liter ( $\mu \mathrm{g} / \mathrm{L})$, and milliequivalents per liter (meq/L). Milligrams per liter and micrograms per liter are units expressing the concentration of chemical constituents in solution as weight of solute (milligrams or micrograms) per unit volume (liter) of water. For concentrations less than $7,000 \mathrm{mg} / \mathrm{L}$, the numerical value of milligrams per liter is equivalent to the concentration in parts per million. The numerical value of micrograms per liter is equivalent to the concentration in parts per billion. Milliequivalents per liter is a unit expressing the concentration of chemical constituents in solution as $1 / 1,000$ the molecular weight, in milligrams, divided by the valence of one molecule of the constituent per unit volume (liter) of water.

Specific conductance is reported in microsiemens per centimeter at 25 degrees Celsius $(\mu \mathrm{S} / \mathrm{cm})$. 
Bacteria is reported in colonies per 100 milliliters (cols./100 mL).

Turbidity is reported in nephelometric turbidity ratio units (NTRU).

Radioactivity is reported in picocuries per liter $(\mathrm{pCi} / \mathrm{L})$.

\section{Isotope Unit Explanations}

Per mil: A unit expressing the ratio of stable-isotope abundances of an element in a sample to those of a standard material. Per mil units are equivalent to parts per thousand. Stable-isotope ratios are computed as follows (Kendall and McDonnell, 1998):

$$
\delta \mathrm{X}=\left\{\left(\mathrm{R}_{\text {sample }}-\mathrm{R}_{\text {standard }}\right) / \mathrm{R}_{\text {standard }}\right\} \times 1,000 \text {, }
$$

where

$\delta$ is the "del" notation,

$\mathrm{X}$ is the heavier stable isotope, and

$R$ is the ratio of the heavier, less abundant isotope to the lighter, stable isotope in a sample or standard.

The $\delta$ values for stable-isotope ratios discussed in this report are referenced to the following standard materials:

\begin{tabular}{lll}
\hline \multicolumn{1}{c}{ Element } & \multicolumn{1}{c}{ R } & \multicolumn{1}{c}{ Standard identity and reference } \\
\hline hydrogen & hydrogen-2/hydrogen-1 & Vienna-Standard Mean Ocean Water (Fritz and Fontes, 1980) \\
oxygen & oxygen-18/oxygen-16 & Vienna-Standard Mean Ocean Water (Fritz and Fontes, 1980) \\
boron & boron-11/boron-10 & $\begin{array}{l}\text { National Bureau of Standards Boric Acid Sample No. 951 } \\
\text { (Catanzaro and others, 1970) }\end{array}$ \\
\hline
\end{tabular}


Blank Page 


\title{
Quality of Groundwater at and near an Aquifer Storage and Recovery Site, Bexar, Atascosa, and Wilson Counties, Texas, June 2004-August 2008
}

\author{
By Cassi L. Otero and Brian L. Petri
}

\section{Abstract}

The U.S. Geological Survey, in cooperation with the San Antonio Water System, did a study during 2004-08 to characterize the quality of native groundwater from the Edwards aquifer and pre- and post-injection water from the Carrizo aquifer at and near an aquifer storage and recovery (ASR) site in Bexar, Atascosa, and Wilson Counties, Texas. Groundwater samples were collected and analyzed for selected physical properties and constituents to characterize the quality of native groundwater from the Edwards aquifer and pre- and post-injection water from the Carrizo aquifer at and near the ASR site. Geochemical and isotope data indicated no substantial changes in major-ion, trace-element, and isotope chemistry occurred as the water from the Edwards aquifer was transferred through a 38-mile pipeline to the aquifer storage and recovery site. The samples collected from the four ASR recovery wells were similar in major-ion and stable isotope chemistry compared to the samples collected from the Edwards aquifer source wells and the ASR injection well. The similarity could indicate that as Edwards aquifer water was injected, it displaced native Carrizo aquifer water, or, alternatively, if mixing of Edwards and Carrizo aquifer waters was occurring, the major-ion and stable isotope signatures for the Carrizo aquifer water might have been obscured by the signatures of the injected Edwards aquifer water. Differences in the dissolved iron and dissolved manganese concentrations indicate that either minor amounts of mixing occurred between the waters from the two aquifers, or as Edwards aquifer water displaced Carrizo aquifer water it dissolved the iron and manganese directly from the Carrizo Sand. Concentrations of radium-226 in the samples collected at the ASR recovery wells were smaller than the concentrations in samples collected from the Edwards aquifer source wells and from the ASR injection well. The smaller radium-226 concentrations in the samples collected from the ASR recovery wells likely indicate some degree of mixing of the two waters occurred rather than continued decay of radium-226 in the injected water. Geochemical and isotope data measured in samples collected in May 2005 from two Carrizo aquifer monitoring wells and in July 2008 from the three ASR production-only wells in the northern section of the ASR site indicate that injected Edwards aquifer water had not migrated to these five sites. Geochemical and isotope data measured in samples collected from Carrizo aquifer wells in 2004, 2005, and 2008 were graphically analyzed to determine if changes in chemistry could be detected. Majorion, trace element, and isotope chemistry varied spatially in the samples collected from the Carrizo aquifer. With the exception of a few samples, major-ion concentrations measured in samples collected in Carrizo aquifer wells in 2004, 2005, and 2008 were similar. A slightly larger sulfate concentration and a slightly smaller bicarbonate concentration were measured in samples collected in 2005 and 2008 from well NC1 compared to samples collected at well NC1 in 2004. Larger sodium concentrations and smaller calcium, magnesium, bicarbonate, and sulfate concentrations were measured in samples collected in 2008 from well WC1 than in samples collected at this well in 2004 and 2005. Larger calcium and magnesium concentrations and a smaller sodium concentration were measured in the samples collected in 2008 at well EC2 compared to samples collected at this well in 2004 and 2005. While in some cases the computed percent differences (compared to concentrations from June 2004) in dissolved iron and dissolved manganese concentrations in 11 wells sampled in the Carrizo aquifer in 2005 and 2008 were quite large, no trends that might have been caused by migration of injected Edwards aquifer water were observed. Because of the natural variation in geochemical data in the Carrizo aquifer and the small data set collected for this study, differences in major-ion and trace element data among the samples collected in 2004, 2005 and 2008 cannot be directly attributed to the ASR site operations. When the data were analyzed graphically, no appreciable differences in isotope concentrations were observed between samples collected in 2004 and 2008 from Carrizo aquifer wells, indicating that the Edwards aquifer source water might not have affected the isotope chemistry of the native Carrizo aquifer water near the sampled Carrizo wells by July 2008. 


\section{Introduction}

The Edwards aquifer is the main source of public water supply for the city of San Antonio in Bexar County, Texas, and adjacent counties and provides nearly all of the water for industrial, military, and irrigation use in the region. Withdrawals from the aquifer are regulated by the Edwards Aquifer Authority (EAA) to protect federally listed endangered species that rely on the discharge at large springs emerging from the aquifer (Edwards Aquifer Authority, 2009). The San Antonio Water System (SAWS) is the primary water provider for the city.

In August 2002, SAWS began construction of an aquifer storage and recovery (ASR) plant in southern Bexar County on an approximately 3,200-acre site that extends into northern Atascosa and western Wilson Counties (fig. 1). Currently (2009) 29 wells at the site are designed to inject water into and withdraw water from the Carrizo aquifer (informal name commonly applied to the upper unit of the Carrizo-Wilcox aquifer in the area). In June 2004 phase one of the ASR plant became operational, enabling SAWS to pump water from the Edwards aquifer when water levels are sufficiently high and withdrawals from the Edwards aquifer are less than the EAA-enforced limit, transfer the water through a 38-mile pipeline (actual length) (Adam E. Conner, San Antonio Water System Planner II, Water Resources, written commun., 2010) to the ASR plant, and inject the water into the Carrizo aquifer through 16 wells. Injected water could then be recovered from the Carrizo aquifer, treated, and distributed during times of drought to alleviate stress on the Edwards aquifer.

The U.S. Geological Survey (USGS), in cooperation with SAWS, did a study during 2004-08 to characterize the quality of groundwater (native water from the Edwards aquifer and pre- and post-injection water from the Carrizo aquifer) at and near the ASR site. Findings of the study are intended to provide a better understanding of possible changes in the quality of groundwater near an active ASR site that might result from the mixing of water from different aquifers. Mobilization of trace elements in groundwater as a result of changes in oxidation and $\mathrm{pH}$ conditions has been observed at other ASR sites (Heilweil and others, 2009). Reduction-oxidation (redox) reaction conditions in an aquifer can change when non-native water is introduced to the aquifer, and redox conditions exercise important controls on water chemistry including several redox-influenced trace elements (Smedley and Edmunds, 2002; Basu and others, 2007). In particular, iron and manganese mobilization was a concern at the SAWS ASR site. The results of this study also are applicable to other ASR investigations in similar hydrogeologic environments and to investigations of the Carrizo-Wilcox aquifer. This study advances the knowledge of how ASR operations affect native groundwater in sandstone aquifers and the hydrologic processes that occur in carbonate/sand aquifer systems. Results of this investigation can be used by local and State water managers to address issues of increased demand for water resources in areas of increasing population.

\section{Purpose and Scope}

This report describes the results of chemical analyses of groundwater samples collected in 2004, 2005, and 2008 from the Carrizo aquifer in parts of Bexar, Atascosa, and Wilson Counties near an ASR site. Water-chemistry and isotope data collected in June 2004 are used to characterize the water of the Carrizo aquifer before the ASR site became operational; data collected in September 2005 and JulyAugust 2008 are used to characterize groundwater near the ASR site after the site became operational. Native water from the Edwards aquifer is analyzed, and a preliminary assessment of the effects on groundwater quality from injecting Edwards aquifer water into the Carrizo aquifer is made using the water-quality data collected during the study. Stormwater samples also were collected from two surface-water quality stations near the ASR site to identify surface-water contaminants, if any, that potentially could enter the Carrizo aquifer through recharge. The ability to collect stormwater samples was dependent on large storms, which were infrequent during the study. Because only eight stormwater samples (representing five storms) could be collected, the stormwater analytical data are included in the appendix but not assessed in the report.

\section{Geology and Hydrogeology}

The Wilcox Group and the overlying Carrizo Sand of the Claiborne Group are important water-yielding formations near the ASR site (fig. 2). The Wilcox Group and Carrizo Sand consist mostly of sand, locally interbedded with gravel, silt, clay, and lignite, that dips into the subsurface toward the Gulf Coast. Most of the sand beds that compose the Wilcox Group are less permeable than those that compose the Carrizo Sand (Klemt and others, 1976).

The Wilcox Group and the hydraulically connected Carrizo Sand together form the Carrizo-Wilcox aquifer, a major aquifer in Texas (Ashworth and Hopkins, 1995). The recharge zone (outcrop) of the Carrizo-Wilcox aquifer forms a relatively narrow band roughly parallel to the Gulf Coast. Recharge to the Carrizo-Wilcox aquifer occurs through direct infiltration of rainfall on the land surface in the recharge zone, through the beds of streams that flow across the recharge zone, and as leakage from overlying formations that compose the Carrizo-Wilcox aquifer in subcrop areas. Water in the aquifer typically is fresh (dissolvedsolids concentration less than 1,000 milligrams per liter) in and near the recharge zone and becomes progressively more saline with distance downdip. The limit of fresh to slightly saline water in the Carrizo-Wilcox aquifer is defined by the southern boundary of the Carrizo-Wilcox subcrop that extends southwest to northeast through south-central Texas. The ASR site is located at the southern margin of the recharge zone (fig. 2).

Part of the ASR site overlies the Carrizo-Wilcox aquifer (Klemt and others, 1976) (fig. 2). The upper unit of 


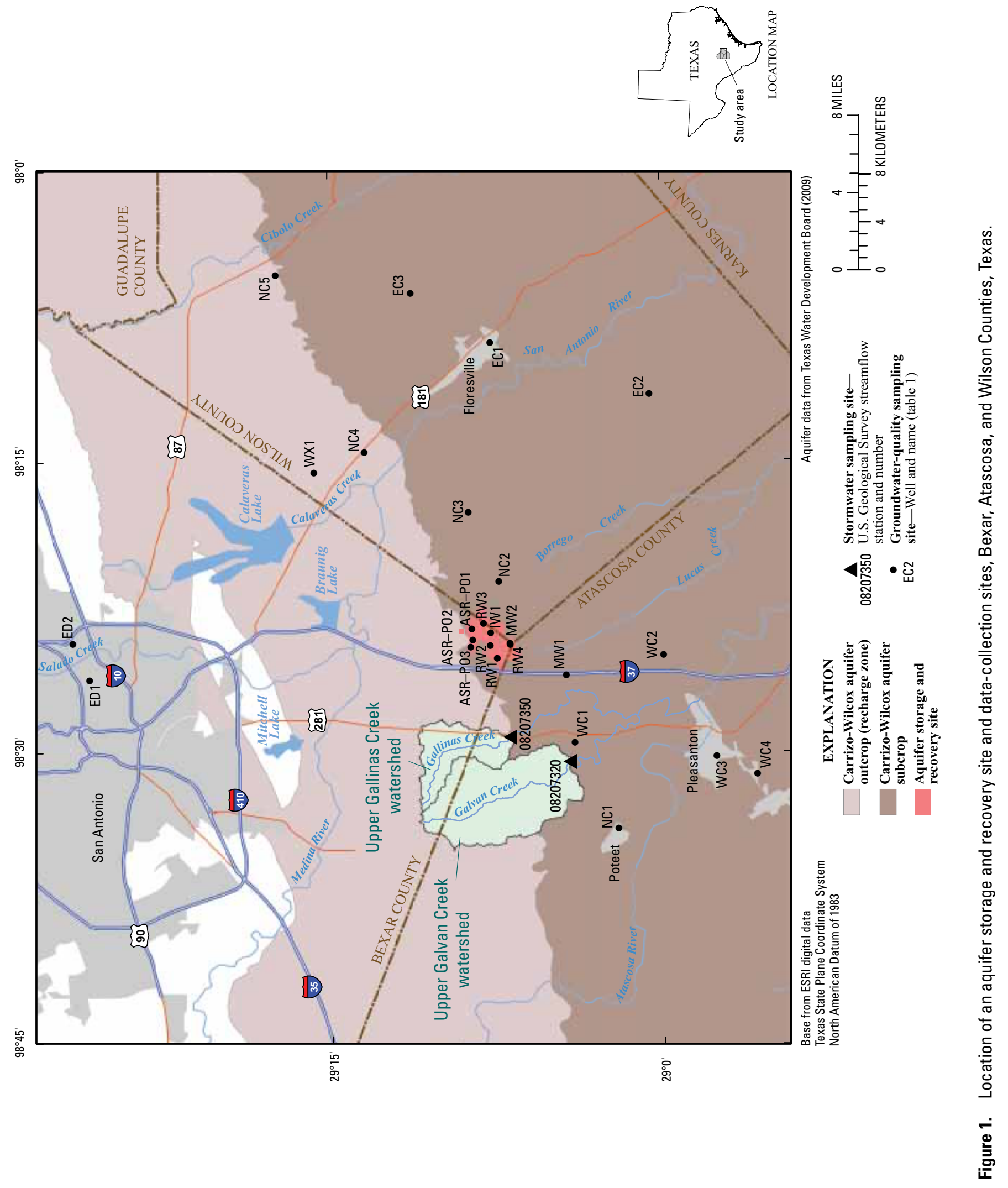



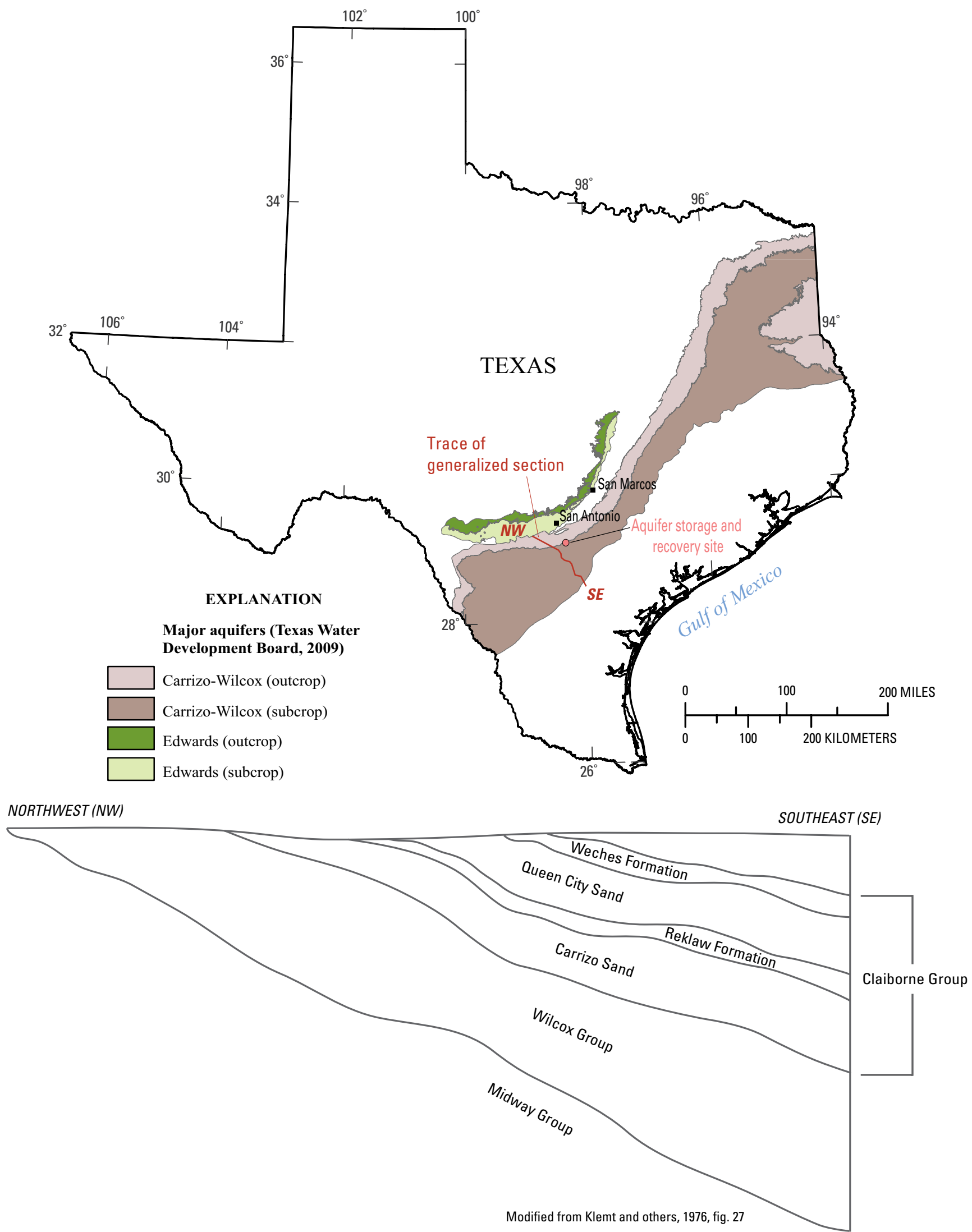

Figure 2. Outcrops and subcrops of the Carrizo-Wilcox aquifer and Edwards aquifer in Texas, and generalized hydrogeologic section of the water-yielding Carrizo Sand and Wilcox Group and other near-surface formations at an aquifer storage and recovery site, Bexar, Atascosa, and Wilson Counties. 
the Carrizo-Wilcox aquifer, the Carrizo Sand, ranges in thickness from 150 to 1,200 feet in south Texas (Klemt and others, 1976, p. 4) and commonly is referred to as the Carrizo aquifer. Some wells screened in the Carrizo aquifer yield more than 1,000 gallons per minute of water (Ashworth and Hopkins, 1995, p. 17), and the Carrizo aquifer is an important source of water for agriculture and public supply.

At the ASR site, the Carrizo aquifer is about 800 feet thick, with a net sand thickness of about 700 feet (Klemt and others, 1976, fig. 9). Haque and Johannesson (2006, p. 59) noted other investigators' findings that "precipitation recharges the Carrizo Sand aquifer in the outcrop area in northwest Atascosa County, and the resulting groundwaters subsequently flow down-gradient towards the southeast (Pearson and White, 1967; Castro et al. [and others], 2000). High fluid pressure causes groundwater to discharge from the aquifer by crossformational upward leakage (Castro and Goblet, 2003)." The prevailing regional flow pattern from northwest to southeast might affect the movement of injected groundwater. The hydrogeologic units above and below the aquifer are moderately confining, on the basis of permeability, relative to that of the Carrizo aquifer. Confining units adjacent to the aquifer at the site tend to keep injected water from migrating vertically into overlying and underlying units, allowing more of the injected water to be withdrawn later.

The water injected at the ASR site is sourced from the San Antonio segment of the Edwards aquifer (hereinafter, Edwards aquifer) (fig. 2). The Edwards aquifer comprises Lower Cretaceous-age rocks of the Edwards Group (Rose, 1972) and the Georgetown Formation. The Edwards Group in the study area comprises two stratigraphic units, the basal Kainer Formation and the upper Person Formation. Each of those units comprises several informal members.

Most recharge to the Edwards aquifer occurs in the recharge zone (aquifer outcrop) west of San Antonio, Tex. (fig. 2), where streams originating north of the aquifer flow across and lose most of all of their flows into highly faulted and fractured limestone. After water enters the aquifer, it moves generally in an easterly direction to discharge points in and near San Antonio, mainly municipal water-supply wells. Water not discharged to wells then continues generally toward the northeast along and parallel to northeast-trending faults in the study area to discharge at major spring complexes.

The thickness of the Edwards aquifer in the study area is about 450 feet (Small and Hanson, 1994, p. 5; Stein and Ozuna, 1994, p. 5). The rocks of the Edwards Group are characterized by a network of en-echelon, high-angle, mostly down-to-the-coast normal faults along the northwestern margin of the Gulf Coast Plain (Maclay and Small, 1984; Maclay, 1995). The faults, and their subsequent erosion and dissolution, are major factors affecting flow in the aquifer. Maclay and Small (1984, p. 50) estimated transmissivities for the Edwards aquifer to range from 200,000 to 2,000,000 feet squared per day.

\section{Methods of Investigation}

Methods described in this report for the water-quality investigation in and near the ASR site in Bexar, Atascosa, and Wilson Counties included components of sample collection, sample analysis, water-chemistry and isotope analysis, and quality control and quality assurance of water-quality samples. At all wells that were sampled, physical properties (dissolved oxygen, $\mathrm{pH}$, specific conductance, water temperature, and alkalinity) and water-quality constituents (major ions, nutrients, and trace elements) were measured. Isotope concentrations (oxygen-16, oxygen-18, hydrogen-1, deuterium, strontium- 86 , strontium- 87 , boron-10, boron- 11 , radium-226, and radium-228) also were measured.

\section{Sample Collection}

Sample collection from Edwards aquifer wells and Carrizo aquifer wells was done following standard USGS methods documented in the "National Field Manual for the Collection of Water-Quality Data" (U.S. Geological Survey, variously dated). Of the 25 wells sampled for this study, 23 had permanently installed pumps from which samples were collected at raw-water spigots at the well heads. The two remaining wells were monitoring wells (wells used only for monitoring water levels and collecting water-quality samples) into which a submersible pump equipped with $3 / 8$-inch Teflon $®$-lined tubing was lowered to collect a raw-water sample. All wells were pumped until field properties stabilized before samples were collected and processed. Field properties were considered stable when the variation between five or more sequential field-measurement readings were within 0.05 unit for $\mathrm{pH}$, 0.2 degree Celsius for temperature, 5 percent for specific conductivity, 0.3 milligram per liter for dissolved oxygen, and 10 percent for turbidity.

\section{Edwards Aquifer Wells}

Water-quality constituent concentrations and physical properties were measured in May 2005 at wells ED1 and ED2 (Edwards aquifer source wells), which are open in the Edwards aquifer at depths of 982 to 1,318 feet; these wells are the source of water that was injected at the ASR site for possible storage and future recovery (fig. 1; tables 1 and 2; appendix 1). Hardrock wells (such as those completed in the Edwards aquifer) typically do not need to be screened or cased because the borehole of a hardrock well will stand open (Harter, 2003). Groundwater-chemistry and isotope data also were collected in May 2005 at the wellhead of injection well 1 (IW1) (ASR injection well), which is screened between depths of 445 and 685 feet in the Carrizo aquifer at the ASR site and used for injecting water from the Edwards aquifer source wells into the Carrizo aquifer. Samples were collected at the ASR injection well before water from the Edwards aquifer was injected into the Carrizo aquifer to indicate whether changes in 
Table 1. Wells from which water samples were collected at and near an aquifer storage and recovery site, Bexar, Atascosa, and Wilson Counties, Texas, 2004-08.

[Datum for open interval and depth to pump intake is land surface; X, open hole; ASR, aquifer storage and recovery; S, screen; N/A, not applicable; --, unknown; G, gravel pack with screen; P, perforated or slotted; F, gravel pack with perforations]

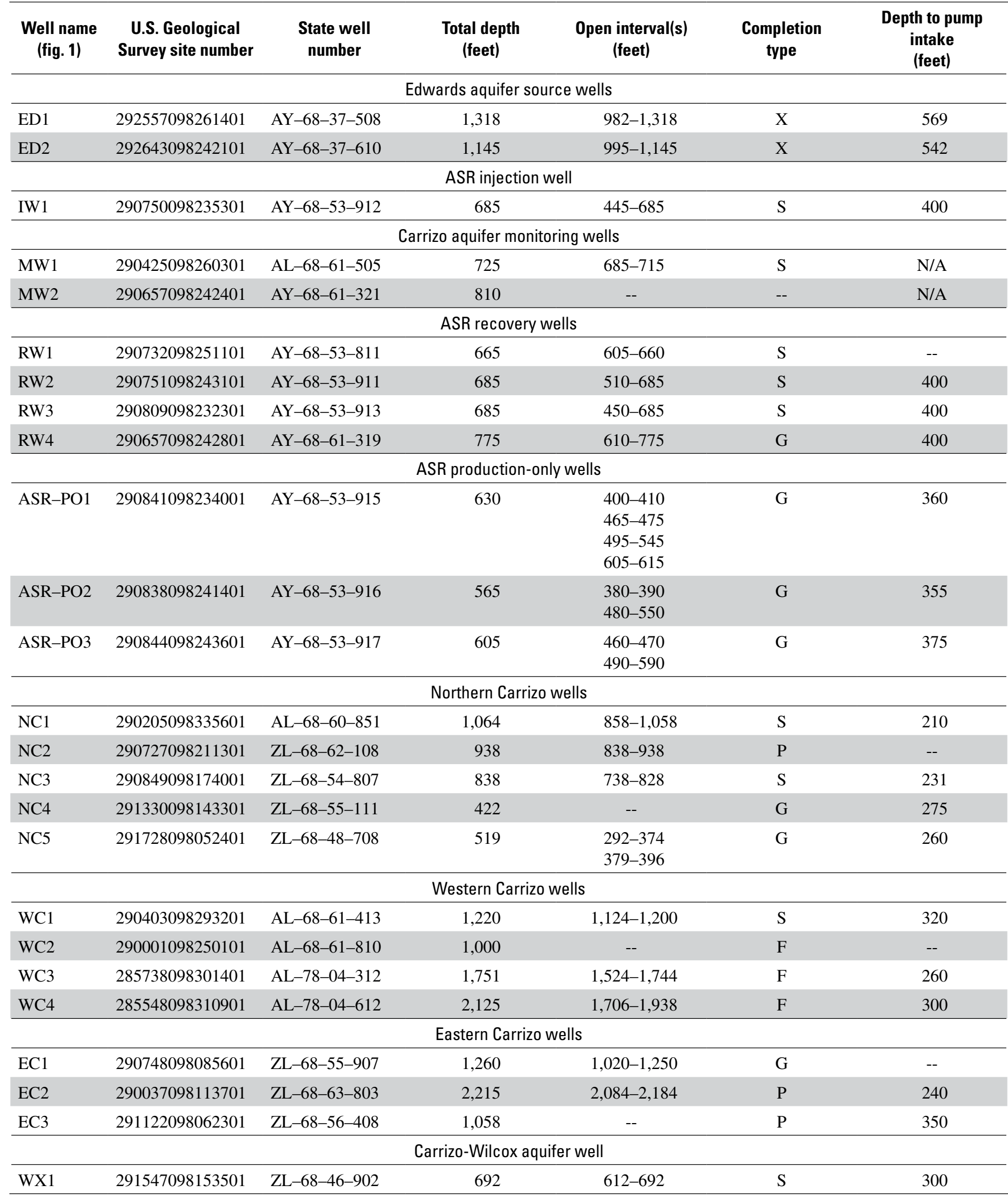


Table 2. Well-sampling schedule by aquifer for samples collected at and near an aquifer storage and recovery site, Bexar, Atascosa, and Wilson Counties, Texas, 2004-08.

\begin{tabular}{|c|c|c|c|c|}
\hline $\begin{array}{c}\text { Well name } \\
\text { (fig. 1) }\end{array}$ & $\begin{array}{l}\text { June } \\
2004\end{array}$ & $\begin{array}{l}\text { May } \\
2005\end{array}$ & $\begin{array}{c}\text { September } \\
2005\end{array}$ & $\begin{array}{c}\text { July- } \\
\text { August } \\
2008\end{array}$ \\
\hline \multicolumn{5}{|c|}{ Edwards aquifer } \\
\hline ED1 & & $\mathrm{X}$ & & \\
\hline ED2 & & $\mathrm{X}$ & & \\
\hline \multicolumn{5}{|c|}{ Carrizo aquifer } \\
\hline & Pre-injection & \multicolumn{3}{|c|}{ Post-injection } \\
\hline IW1 & & $\mathrm{X}$ & & \\
\hline MW1 & & $\mathrm{x}$ & & \\
\hline MW2 & & $\mathrm{x}$ & & \\
\hline RW1 & & & & $\mathrm{X}$ \\
\hline RW2 & & & & $\mathrm{X}$ \\
\hline RW3 & & & & $\mathrm{X}$ \\
\hline RW4 & & & & $\mathrm{X}$ \\
\hline ASR-PO1 & & & & $\mathrm{X}$ \\
\hline ASR-PO2 & & & & $\mathrm{X}$ \\
\hline ASR-PO3 & & & & $\mathrm{X}$ \\
\hline $\mathrm{NC} 1$ & $\mathrm{X}$ & & $\mathrm{X}$ & $\mathrm{X}$ \\
\hline $\mathrm{NC} 2$ & $\mathrm{X}$ & & & $\mathrm{X}$ \\
\hline NC3 & $\mathrm{X}$ & & $\mathrm{X}$ & $\mathrm{X}$ \\
\hline $\mathrm{NC4}$ & $\mathrm{X}$ & & $\mathrm{X}$ & $\mathrm{X}$ \\
\hline NC5 & $\mathrm{X}$ & & & \\
\hline WC1 & $\mathrm{X}$ & & $\mathrm{x}$ & $\mathrm{X}$ \\
\hline WC2 & $\mathrm{X}$ & & $\mathrm{X}$ & \\
\hline WC3 & $\mathrm{X}$ & & $\mathrm{X}$ & $\mathrm{X}$ \\
\hline WC4 & $\mathrm{X}$ & & $\mathrm{X}$ & $\mathrm{X}$ \\
\hline $\mathrm{EC} 1$ & $\mathrm{X}$ & & $\mathrm{x}$ & $\mathrm{X}$ \\
\hline $\mathrm{EC} 2$ & $\mathrm{X}$ & & $\mathrm{X}$ & $\mathrm{X}$ \\
\hline EC3 & $\mathrm{X}$ & & & \\
\hline \multicolumn{5}{|c|}{ Carrizo-Wilcox aquifer } \\
\hline WX1 & $\mathrm{X}$ & & $\mathrm{X}$ & $\mathrm{X}$ \\
\hline
\end{tabular}

water chemistry occurred when transferring the water through a 38-mile pipeline from the source wells to the ASR site.

\section{Carrizo Aquifer Wells}

Pre-injection Carrizo aquifer water was characterized by samples collected from 12 wells ( NC1, NC2, NC3, NC4, NC5-northern Carrizo wells; WC1, WC2, WC3, WC4western Carrizo wells; EC1, EC2, EC3-eastern Carrizo wells) in the Carrizo aquifer screened at depths of 292 to 2,184 feet (fig. 1; table 1). Wells completed in alluvial aquifers (such as the Carrizo aquifer) are screened at specific depth intervals to ensure that screened zones match the aquifer zones from which water will be drawn (Harter, 2003). The analytical results from one additional well, WX1 (Wilcox-Carrizo well), intended to characterize the Carrizo aquifer were different from the analytical results of the 12 Carrizo wells. Prior to sampling, well WX1, screened between depths of 612 and 692 feet, was believed to be screened in the Carrizo aquifer; additional investigation after the analytical results were obtained, including a careful review of well logs, indicated well WX1 was partially screened in the Wilcox Group of the Carrizo-Wilcox aquifer. Analytical results from well WX1 thus were not used to characterize the Carrizo aquifer. The locations of wells from which water samples were collected at and near the ASR site, including the Carrizo aquifer well locations, are shown in figure 1. Samples from the 12 Carrizo wells and the Carrizo-Wilcox well were collected in June 2004 (table 2) before injection of Edwards aquifer water into the Carrizo aquifer. Hereinafter, samples collected during June 2004 in the 12 Carrizo wells are referred to as the 2004 Carrizo samples.

Post-injection Carrizo aquifer water near the ASR site was characterized after injection of Edwards aquifer water began at the ASR site. Water-quality samples were collected at selected subsets of the 12 Carrizo wells during September 2005 (hereinafter 2005 Carrizo samples) and during JulyAugust 2008 (hereinafter, 2008 Carrizo samples). Most of the Carrizo wells sampled in 2004 were resampled in 2005 and 2008. Two wells (EC3 and NC5) sampled in 2004 were not sampled in either 2005 or 2008 because they were beyond a 15-mile radius (centered on the ASR site), which was a criterion for well selection implemented after the 2004 sampling. The 15-mile radius was decided upon because that is the distance from the ASR site to the San Antonio River, which is a gaining stream that might prevent groundwater from flowing past the stream from either direction. One well (NC2) could not be sampled in 2005 because of pump problems but was sampled in 2008; another well (WC2) was sampled in 2005 but was unavailable for sampling during July-August 2008. Two additional wells (MW1 and MW2; hereinafter, Carrizo aquifer monitoring wells) at and near the ASR site and screened at depths of 685 to 715 feet and completed in an unknown manner to about 810 feet, respectively, in the Carrizo aquifer were sampled in May 2005. Samples also were collected in July 2008 at four Carrizo aquifer wells (RW1, RW2, RW3, and RW4; hereinafter, ASR recovery wells) to characterize post-injection water from the Carrizo aquifer; these wells, screened at depths of 450 to 775 feet, were used for recovery of injected water. To indicate the extent to which injected Edwards aquifer water might migrate north, three wells (ASR-PO1, ASR-PO2, and ASR-PO3; hereinafter, ASR production-only wells) on the north side of the ASR site were sampled in July 2008; these wells were designed to pump water from, but not inject water into, the Carrizo aquifer. 


\section{Sample Analysis}

Physical property (dissolved oxygen, $\mathrm{pH}$, specific conductance, and water temperature), major-ion, alkalinity, and trace-element data were obtained for all groundwater samples that were collected (appendix 1). The 2004 Carrizo samples also were analyzed for nutrients. Trace-element concentrations were measured for the dissolved phase. Prior to analysis, water samples analyzed for dissolved-phase constituents were filtered through a 0.45 -micrometer membrane filter and acidified with ultrapure nitric acid to $\mathrm{pH}$ less than 2 standard units (Garbarino and Taylor, 1996). In addition to analyzing for dissolved iron and manganese, total-phase (whole water) iron and manganese concentrations in groundwater were measured by analyzing unfiltered samples that had undergone an in-bottle acid digestion process (Garbarino and Struzeski, 1998).

Stable isotope data were analyzed for all samples except the 2005 Carrizo samples. Water samples were collected, processed, and preserved using standard USGS protocols as described in the "National Field Manual for the Collection of Water-Quality Data" (U.S. Geological Survey, variously dated). The concentrations of major ions, nutrients, and trace elements in the water samples were analyzed by the USGS National Water Quality Laboratory (NWQL) in Denver, Colo., using approved methods (Fishman and Friedman, 1989; Patton and Truitt, 1992, 2000; Fishman, 1993; Garbarino and Struzeski, 1998; Garbarino, 1999; Garbarino and others, 2006).

Stable environmental isotopes are measured as the ratio of the two most abundant isotopes of a given element. The most abundant isotopes of oxygen are oxygen-18 $\left({ }^{18} \mathrm{O}\right)$ and oxygen- $16\left({ }^{16} \mathrm{O}\right)$, whereas the most abundant isotopes of hydrogen are hydrogen-2 $\left({ }^{2} \mathrm{H}\right)$ and hydrogen-1 $\left({ }^{1} \mathrm{H}\right)$ (Clark and Fritz, 1997). Water molecules with a greater amount of the lightest oxygen and hydrogen isotopes $\left({ }^{16} \mathrm{O}\right.$ and ${ }^{1} \mathrm{H}$, respectively) evaporate preferentially compared to water molecules with a greater amount of the heaviest oxygen and hydrogen isotopes $\left({ }^{18} \mathrm{O}\right.$ and ${ }^{2} \mathrm{H}$, respectively) (Bruckner, 2009). The USGS Isotope Tracers Project (U.S. Geological Survey, 2004) provides a description of stable isotope compositions:

"The stable isotopic compositions of low-mass (light) elements such as oxygen and hydrogen are normally reported as "delta" values $\left(\delta^{18} \mathrm{O}\right.$ for oxygen and $\delta \mathrm{D}$ for hydrogen) in parts per thousand enrichments or depletions relative to a standard of known composition. For the element oxygen, the average terrestrial abundance ratio of ${ }^{18} \mathrm{O}$ to ${ }^{16} \mathrm{O}$ is $1: 500$; the average ratio of ${ }^{2} \mathrm{H}$ to ${ }^{1} \mathrm{H}$ is 1:6,410 (Kendall and Caldwell, 1998). A positive $\delta \mathrm{D}$ or $\delta^{18} \mathrm{O}$ value means that the sample contains more of the heavy isotope than the standard; a negative $\delta \mathrm{D}$ or $\delta^{18} \mathrm{O}$ value means that the sample contains less of the heavy isotope than the standard."

The ratios of naturally occurring, stable isotopes of hydrogen $\left({ }^{2 / 1} \mathrm{H}\right)$ and oxygen $\left({ }^{18 / 16} \mathrm{O}\right)$ of water were measured by the USGS Stable Isotope Laboratory in Reston, Va., using approved methods (Epstein and Mayeda, 1953; Coplen and others, 1991). The ratios of naturally occurring, stable isotopes of strontium (strontium-87/strontium-86 [ $\left.{ }^{87 / 86} \mathrm{Sr}\right]$ ) and boron (boron-11/boron-10 [11/10 B]) were measured by the USGS National Research Program Laboratory in Menlo Park, Calif., using approved methods (Bayless and others, 2004). Natural radium is composed of four isotopes (Focazio and others, 2001), two of which were analyzed for this study: radium-226 $\left({ }^{226} \mathrm{Ra}\right)$ and radium-228 $\left({ }^{228} \mathrm{Ra}\right) .{ }^{226} \mathrm{Ra}$ and ${ }^{228} \mathrm{Ra}$ isotopes were analyzed by Eberline Services in Richmond, Calif., using U.S. Environmental Protection Agency methods 903.1 and 904.0 (U.S. Environmental Protection Agency, 1980), respectively. Results for stable isotope analysis of ${ }^{2 / 1} \mathrm{H}$ and ${ }^{18 / 16} \mathrm{O}$ are reported as delta deuterium $(\delta \mathrm{D})$ and delta 18-oxygen $\left(\delta^{18} \mathrm{O}\right)$, respectively, which represent the relative difference in parts per thousand (per mil) between the sample isotope ratio and the isotope ratio of a known standard (Kendall and McDonnell, 1998). The molar ratio ${ }^{87 / 86} \mathrm{Sr}$ is computed by dividing the concentration of ${ }^{87} \mathrm{Sr}$, in moles per liter, by the concentration of ${ }^{86} \mathrm{Sr}$, in moles per liter. A molar ratio is dimensionless. Results for stable isotope analysis of ${ }^{11 / 10} \mathrm{~B}$ are reported as delta 11-boron $\left(\delta^{11} \mathrm{~B}\right)$ (Davidson and Bassett, $1993)$ and as the molar ratio of ${ }^{11} \mathrm{~B}$ to ${ }^{10} \mathrm{~B}\left({ }^{11 / 10} \mathrm{~B}\right)$. The values for all ${ }^{226} \mathrm{Ra}$ and ${ }^{228} \mathrm{Ra}$ concentrations are reported in picocuries per liter. Focazio and others (2001, p. v) explain "picocuries per liter is a unit expressing the concentration (or activity) of radionuclides in solution as particles emitted per unit volume (liter) of water. By definition, 1 gram of radium has 1 curie of activity. A picocurie is a millionth of a millionth of a curie. In practical terms, 1 picocurie per liter equals 2.2 radioactive disintegrations per minute per unit volume (liter) of water."

The precision estimate (PE), a common term for radium isotope measurement uncertainty or measurement error (for example, see Inoue and Komura, 2007), was computed at 2 standard deviations (2-sigma) about the count value and the sample-specific critical level $\left(\mathrm{ssL}_{\mathrm{C}}\right)$ for ${ }^{226} \mathrm{Ra}$ and ${ }^{228} \mathrm{Ra}$. The $\mathrm{ssL}_{\mathrm{C}}$ is the smallest measured concentration calculated from measurements obtained using the same analytical parameter values that were used during the analysis of a sample that is statistically different from the instrument background or analytical blank, and it serves as the detection threshold for deciding whether the radionuclide is present in a sample (McCurdy and others, 2008).

Two stormwater-sample collection sites were established in the study area on small basins in Atascosa County near the ASR site (fig. 1). The drainage area for the western site, USGS streamflow station 08207320 Galvan Creek near Leming, Tex., is 28.4 square miles. The Carrizo Sand and Reklaw Formation are exposed in the upper Galvan Creek watershed. The drainage area for the eastern site, USGS streamflow station 08207350 Gallinas Creek near Leming, Tex., is 11.9 square miles. The Carrizo Sand is exposed in the upper Gallinas Creek watershed. Water-quality data were collected from these sites to help determine what contaminants, if any, might be 
entering the Carrizo aquifer through the recharge of runoff following storms.

Stormwater samples were collected from the Galvan Creek and Gallinas Creek sites between April 2004 and February 2005. Selected field properties ( $\mathrm{pH}$ and specific conductance) were measured and selected water-quality constituents (nutrients, trace elements, oil and grease, and pesticides) were analyzed in the stormwater samples (appendix 3). The Galvan Creek and Gallinas Creek sites were equipped with automatic water samplers programmed to take discrete samples every 30 minutes from a single point in the channel over the duration of a period of runoff. These discrete samples were combined into one flow-weighted composite storm sample per site. In addition to the composite samples, discrete grab samples were collected and analyzed for bacteria (appendix 4) at the USGS Texas Water Science Center in San Antonio, Tex. Four composite and four grab samples were collected at each stormwater-sample collection site. The eight samples represented five discrete storms. Stormwater samples were collected, processed, and preserved using standard USGS protocols as described in the "National Field Manual for the Collection of Water-Quality Data" (U.S. Geological Survey, variously dated). The concentrations of nutrients, trace elements, oil and grease, and pesticides in the water samples were measured by the USGS NWQL in Denver, Colo., using approved methods (Wershaw and others, 1987; Fishman and Friedman, 1989; Patton and Truitt, 1992, 2000; Fishman, 1993; Garbarino and others, 2006).

\section{Water-Chemistry and Isotope Analysis}

Water-chemistry and isotope data were analyzed to evaluate the quality of water in the Carrizo aquifer before and after water from the Edwards aquifer was injected at the ASR site. Water-chemistry and isotope data also were used to evaluate whether any change in water-chemistry or isotope composition occurred in the Edwards aquifer source water as it was transferred through a 38-mile pipeline to the ASR site.

Major-ion, trace element, and isotope data were graphically evaluated to indicate differences between samples of the Edwards aquifer source water before it was injected at the ASR site and samples of native (pre-injection of Edwards aquifer water) Carrizo aquifer water collected from wells near the ASR site, and to assess changes in pre- and post-injection quality of water in the Carrizo aquifer in the study area. For wells sampled more than once, a trilinear diagram (Hem, 1992) and Stiff diagrams (Stiff, 1951) were constructed using major-ion chemistry data to depict changes in water composition. Water composition is depicted as percentage milliequivalents in a trilinear diagram and concentrations of milliequivalents per liter in a stiff diagram. Iron and manganese concentrations, which were observed to be generally much larger in water from the Carrizo aquifer than in water from the Edwards aquifer, were used as indicators of whether the injected Edwards aquifer water might be causing any changes in water chemistry at wells screened in the Carrizo aquifer at or near the ASR site. The major concern was that the injected chlorinated, oxygen-rich Edwards aquifer water might cause an increase in iron or manganese precipitation in parts of the Carrizo aquifer where reducing conditions might be present. Scatter plots of stable isotope data measured in samples collected from the Carrizo aquifer were constructed to help discern whether any changes in isotope chemistry occurred before and after the injection of water from the Edwards aquifer into the Carrizo aquifer.

\section{Quality Control and Quality Assurance of Water- Quality Samples}

Quality-assurance procedures outlined in the "National Field Manual for the Collection of Water-Quality Data" (U.S. Geological Survey, variously dated) were followed for collecting and processing water-quality samples. Three duplicate samples were collected to evaluate potential bias, variability, or contamination introduced during sample collection, processing, or laboratory analysis (appendix 2). Duplicate samples for major ions, nutrients, and trace elements were collected at well WX1 in June 2004. Duplicate samples for major ions and trace elements were collected at well WC2 in September 2005. Duplicate samples were collected for major ions, trace elements, and isotopes at well EC1 in August 2008.

Duplicate samples were compared to the associated environmental samples by calculating the relative percent difference (RPD) for each pair of detected constituents (appendix 2). The RPD was not computed for a constituent pair if one or both of the concentrations either were less than the long-term method detection level (LT-MDL) (nondetection) or were reported as estimated. An estimated concentration is measured between the LT-MDL and the laboratory reporting level, or LRL (two times the LT-MDL) and concentrations less than the LT-MDL are reported as less than the LRL (Childress and others, 1999). Of the total 112 constituent pairs, RPD was computed for 71 pairs. RPD was computed using the equation

$$
\mathrm{RPD}=\left|\mathrm{C}_{1}-\mathrm{C}_{2}\right| /\left(\left(\mathrm{C}_{1}+\mathrm{C}_{2}\right) / 2\right) \times 100
$$

$$
\begin{aligned}
& \text { where } \\
& \qquad \begin{array}{l}
C_{1}=\text { concentration from environmental sample; and } \\
C_{2}=\text { concentration from duplicate sample. }
\end{array}
\end{aligned}
$$

RPDs of 15 percent or less indicate good agreement between analytical results if the concentrations are sufficiently large compared to the LRL. For sample pairs for which RPD was computed, the RPD was within 15 percent for all 27 sample pairs of major ions, both sample pairs for nutrients, 30 of 35 sample pairs for trace elements, and all seven sample pairs for isotopes. RPDs of zero were computed for nine sample pairs for major ions, one sample pair for nutrients, and 11 sample pairs for trace elements. The non-zero RPDs between environmental and duplicate samples collected for major ions, nutrients, and trace elements for this study ranged from 0.14 
percent for magnesium in well WC2 to 97.7 percent for dissolved iron in well WC2 with a median value of 1.28 percent. The non-zero RPDs between environmental and duplicate samples collected for isotopes for this study ranged from 0.003 percent for ${ }^{87 / 86} \mathrm{Sr}$ to 14.0 percent for $\delta^{11} \mathrm{~B}$ in well $\mathrm{EC} 1$ with a median of 1.74 percent. Four of the five sample pairs with RPDs exceeding 15 percent for trace elements (dissolved iron being the exception; LRL 6 micrograms per liter $[\mu \mathrm{g} / \mathrm{L}]$ ) had concentrations that were not sufficiently large compared to the LRL, resulting in a large RPD from a small difference between concentrations.

\section{Quality of Groundwater}

Groundwater quality was assessed by aquifer. Water from wells providing Edwards aquifer water for injection into the ASR site was analyzed. Water from wells in the Carrizo aquifer near the ASR site was analyzed before injection of Edwards aquifer water. Water from wells in the Carrizo aquifer both at and near the ASR site was analyzed after injection of Edwards aquifer water to determine how much, if any, mixing of the injected Edwards aquifer water with the native Carrizo aquifer water was evident.

\section{Edwards Aquifer}

\section{Major-Ion Chemistry}

The major-ion chemistry of groundwater samples collected in May 2005 from the Edward aquifer source wells is indicative of calcium-bicarbonate type water, the dominant groundwater type in the freshwater section of the Edwards aquifer (Lambert and others, 2000; Fahlquist and Ardis, 2004; Otero, 2007). No substantial differences were measured in major-ion chemistry of water samples collected from the ASR injection well compared to major-ion chemistry of water samples collected from the Edwards aquifer source wells (appendix 1). This similarity in the major-ion chemistry indicates no substantial changes in major-ion chemistry occurred as the water was transferred through a 38-mile pipeline from the Edwards aquifer source wells to the ASR injection well.

\section{Trace-Element Chemistry}

In the water samples collected from the two Edwards aquifer source wells and the ASR injection well, the dissolved iron concentrations were less than $6 \mu \mathrm{g} / \mathrm{L}$ (LRL) and dissolved manganese concentrations ranged from less than $0.2 \mu \mathrm{g} / \mathrm{L}$ (LRL) to $0.3 \mu \mathrm{g} / \mathrm{L}$ (appendix 1). No substantial differences were measured in trace-element chemistry of water samples collected from the ASR injection well compared to the trace-element chemistry of water samples collected from the Edwards aquifer source wells (appendix 1). The similarity in the trace-element chemistry indicates no substantial changes in trace-element water chemistry occurred as the water was transferred through a 38-mile pipeline from the Edwards aquifer source wells to the ASR injection well.

\section{Isotopes}

The relation between $\delta \mathrm{D}$ and $\delta^{18} \mathrm{O}$ in water samples collected from 25 wells is shown in figure 3 . Two meteoric water lines are shown in figure 3. Craig (1961) constructed the global meteoric water line using isotopic signatures from precipitation all over the world, whereas Otero (2007) constructed the local meteoric water line (LMWL) using isotopic signatures from precipitation in south-central Texas. Samples from the Edwards aquifer source wells plotted below the LMWL of $\delta \mathrm{D}=8.8032 \delta^{18} \mathrm{O}+17.825$ calculated by Otero (2007), indicating that the lighter water molecules were preferentially removed by evaporation before any precipitation could enter the Edwards aquifer as recharge. Similarity of $\delta \mathrm{D}$ and $\delta^{18} \mathrm{O}$ values in samples collected from Edwards aquifer source wells (represented by triangles in fig. 3) and the ASR injection well (represented by a rectangle in fig. 3) (appendix 1) indicates that little, if any, evaporation of water piped from the Edwards aquifer occurred within the pipeline connecting the Edwards aquifer source wells to the ASR injection well.

The relation between ${ }^{87 / 86} \mathrm{Sr}$ and ${ }^{11 / 10} \mathrm{~B}$ ratios in water samples collected from 24 wells $\left({ }^{11 / 10} \mathrm{~B}\right.$ not measured in NC5) is shown in figure 4 . Similar ${ }^{87 / 86} \mathrm{Sr}$ and ${ }^{11 / 10} \mathrm{~B}$ ratios were measured in the samples from the Edwards aquifer source wells and the ASR injection well (a 38-mile pipeline between source wells and injection well), consistent with the similar isotopic ratios of $\delta \mathrm{D}$ and $\delta^{18} \mathrm{O}$ (fig. 3) measured in samples from these same wells. In samples collected from the Edwards aquifer source wells, ${ }^{87 / 86} \mathrm{Sr}$ ratios ranged from 0.70785 in well ED1 to 0.70790 in well $\mathrm{ED} 2$ and ${ }^{11 / 10} \mathrm{~B}$ ratios ranged from 4.157 in well ED2 to 4.161 in well ED1. In the sample from the ASR injection well, ${ }^{87 / 86} \mathrm{Sr}$ and ${ }^{11 / 10} \mathrm{~B}$ ratios were 0.70790 and 4.154 , respectively.

The relation between ${ }^{226} \mathrm{Ra}$ and ${ }^{228} \mathrm{Ra}$ in water samples collected from 25 wells is shown in figure 5 . The concentrations of ${ }^{226} \mathrm{Ra}$ in the samples collected from the Edwards aquifer source wells (represented by the triangle symbol in fig. 5) were 0.639 and 0.644 picocurie per liter (pCi/L); the concentration of ${ }^{228} \mathrm{Ra}$ was $0.230 \mathrm{pCi} / \mathrm{L}$ in well ED1 and a nondetection in well ED2. In the ASR injection well (represented by the rectangle symbol in fig. 5) ${ }^{226} \mathrm{Ra}$ and ${ }^{228} \mathrm{Ra}$ concentrations $(0.624 \mathrm{pCi} / \mathrm{L}$ and $0.285 \mathrm{pCi} / \mathrm{L}$, respectively) were similar to concentrations in the Edwards aquifer source wells. The similarity in radium isotope concentrations in samples collected from the Edwards aquifer source wells and ASR injection well provides additional evidence of no substantial change in the water quality as the water was piped from the Edwards aquifer source wells to the ASR site. 


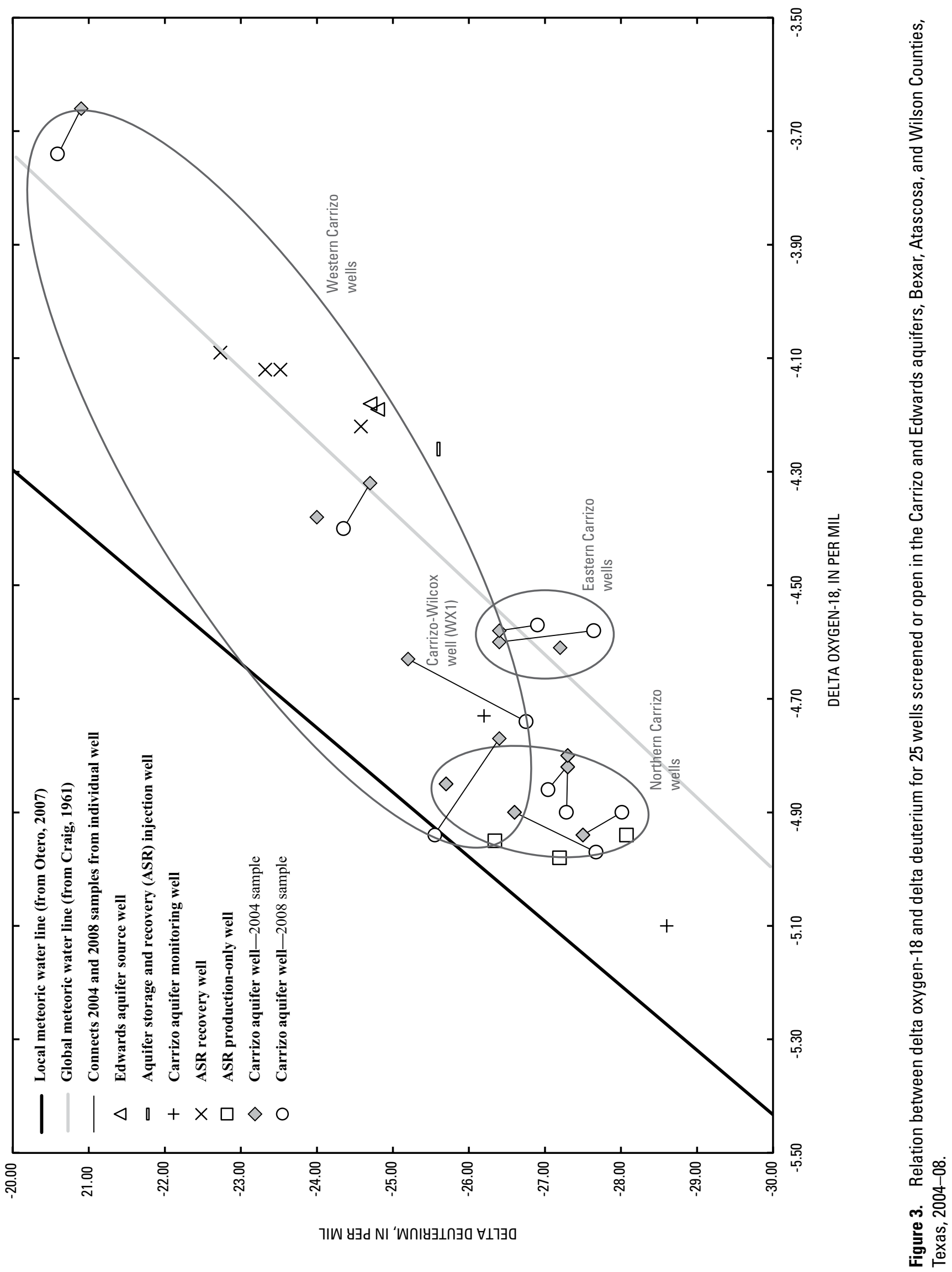




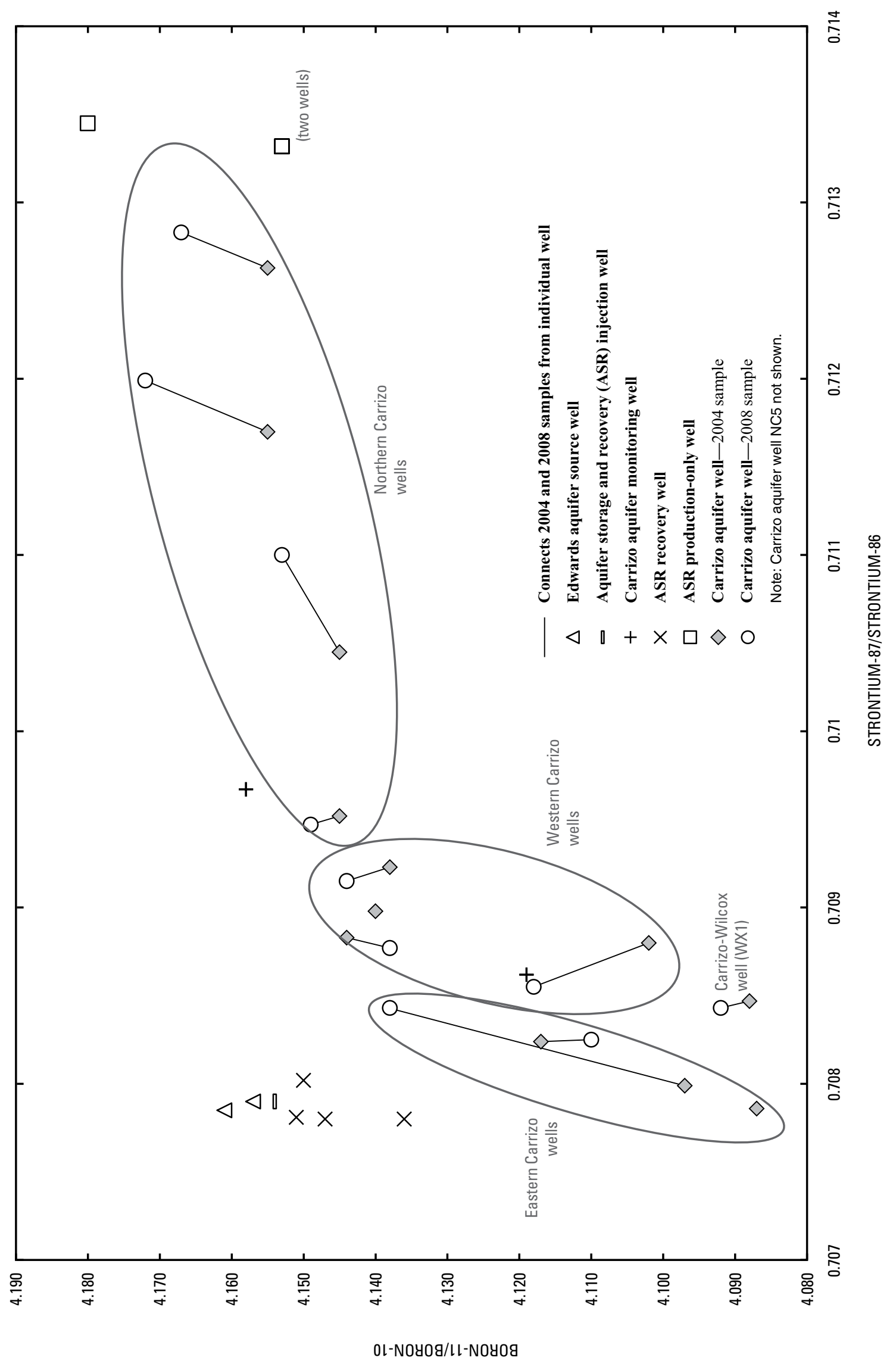

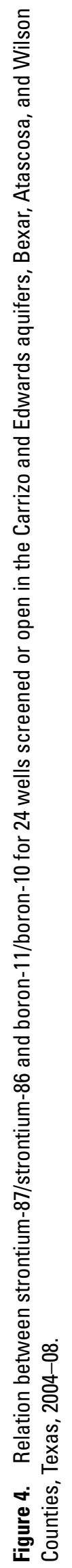




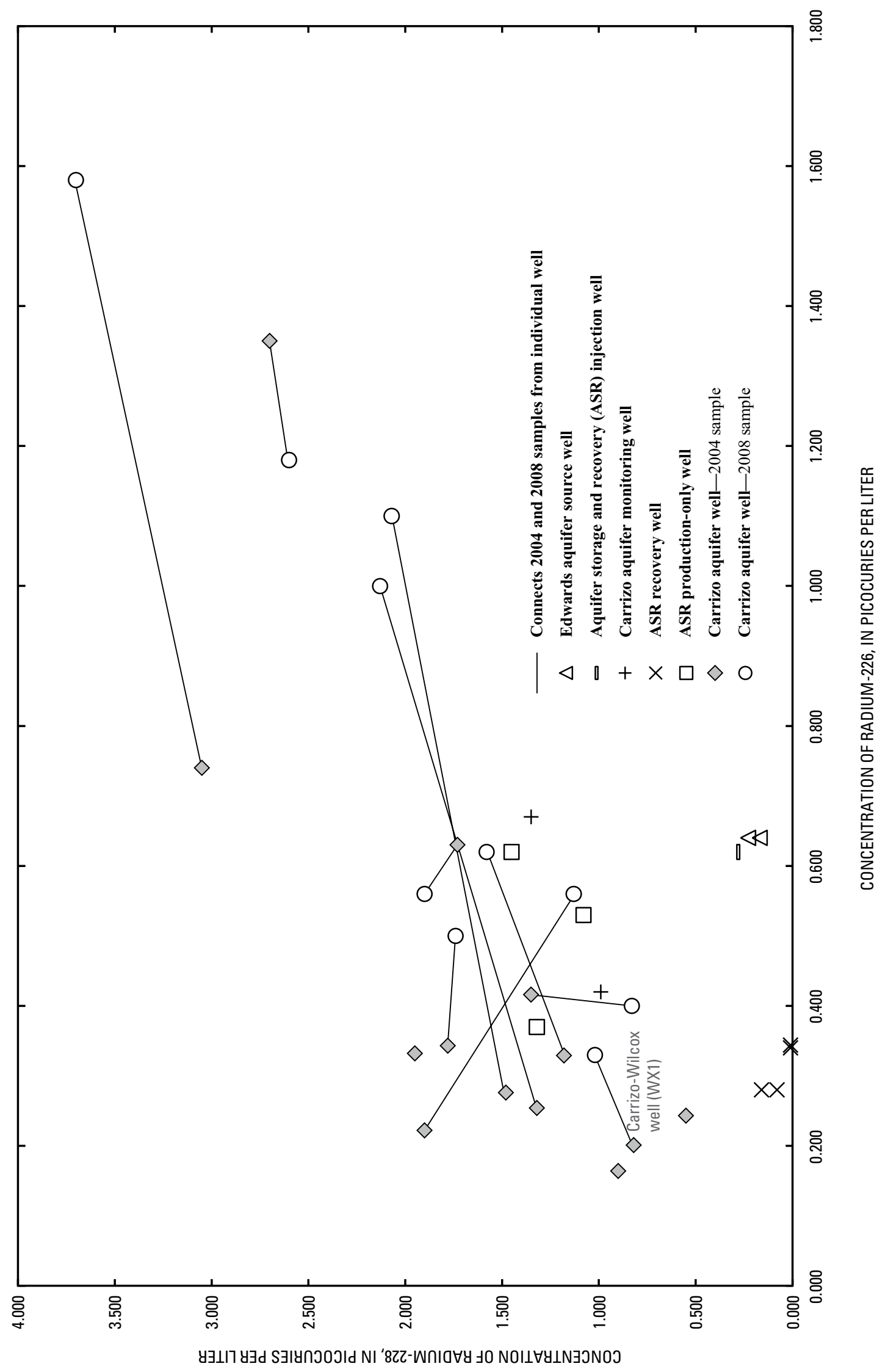




\section{Pre-Injection Carrizo Aquifer}

Before any water from the Edwards aquifer was injected at the ASR site, the quality of groundwater in the Carrizo aquifer was assessed. Samples were collected from the 12 Carrizo wells (2004 Carrizo samples) and the Carrizo-Wilcox well within a 20 -mile radius of the ASR site.

\section{Major-Ion Chemistry}

Calcium, sodium, bicarbonate, and chloride concentrations in the samples collected from the Carrizo wells varied greatly in the study area, resulting in a wide range of water types. Stiff diagrams (Stiff, 1951) were constructed using the major-ion chemistry from the 2004, 2005, and 2008 Carrizo samples (fig. 6). Because well WX1 is screened in the Wilcox Group, it is not shown in figure 6. Wells NC1, NC2, NC3, $\mathrm{NC} 4$, and NC5 (northern Carrizo wells), screened at depths of 292 to 1,058 feet below land surface in the recharge zone and shallow sections of the confined Carrizo aquifer, produced water with small concentrations of major ions, as indicated by the narrow shape of the stiff diagram (fig. 6). Wells WC1, WC2, WC3, and WC4 (western Carrizo wells), screened at depths ranging from 1,124 to 1,938 feet below land surface, produced water with relatively large calcium concentrations compared to water sampled from the other wells in the study area, as indicated by the diamond-shaped stiff diagram (fig. 6). Wells EC1, EC2, and EC3 (eastern Carrizo wells), completed at depths ranging from 1,020 to 2,184 feet below land surface, produced water with relatively large sodium and bicarbonate concentrations compared to the other wells in the study area, as indicated by stiff diagrams that roughly resemble a rightpointing arrow (fig. 6).

\section{Trace-Element Chemistry}

In the 2004 Carrizo samples, dissolved iron concentrations ranged from less than $6 \mu \mathrm{g} / \mathrm{L}$ (LRL) in well WC2 to $2,550 \mu \mathrm{g} / \mathrm{L}$ in well NC2, whereas dissolved manganese concentrations ranged from $8.2 \mu \mathrm{g} / \mathrm{L}$ in well EC3 to $132 \mu \mathrm{g} / \mathrm{L}$ in well WC3 (table 3; appendix 1). The largest dissolved iron concentrations in the study area were generally measured in samples collected from the Northern Carrizo wells $(1,130$ to $2,550 \mu \mathrm{g} / \mathrm{L})$. The dissolved iron concentration measured in the sample collected from well WX1 was $109 \mu \mathrm{g} / \mathrm{L}$, which was smaller than the dissolved iron concentrations measured in samples from any northern Carrizo wells. Although well WX1 is in the same area as the northern Carrizo wells, it penetrates the Wilcox Group. 2004 Carrizo samples from all western Carrizo wells, except WC3, had the smallest dissolved iron concentrations in the study area, ranging from less than $6 \mu \mathrm{g} / \mathrm{L}$ (LRL) to $10 \mu \mathrm{g} / \mathrm{L}$. Well WC3, with major-ion chemistry similar to that of the other western Carrizo wells, had the largest dissolved iron concentration $(124 \mu \mathrm{g} / \mathrm{L})$ compared to samples from the remaining western Carrizo wells; however, the dissolved iron concentration from WC3 was smaller compared to samples from northern Carrizo wells. Dissolved iron concentrations ranged from 16 to $363 \mu \mathrm{g} / \mathrm{L}$ in samples from the eastern Carrizo wells. Dissolved manganese concentrations in 2004 Carrizo samples varied greatly throughout the study area and generally were smaller in eastern Carrizo wells compared to all other Carrizo wells.

\section{Isotopes}

In the graph showing the relation between $\delta \mathrm{D}$ and $\delta^{18} \mathrm{O}$ (fig. 3), all 2004 Carrizo samples plot below the LMWL line calculated by Otero (2007), indicating that the lighter water molecules were preferentially removed, by various amounts of evaporation, from the precipitation before any of it entered the Carrizo aquifer as recharge. Similar to the highly variable major-ion and trace-element concentrations in the 2004 Carrizo samples, isotope concentrations and ratios in the 2004 Carrizo samples also were highly variable. $\delta$ D ranged from -27.50 per mil in well $\mathrm{NC} 1$ to -20.90 per mil in well WC4, whereas $\delta^{18} \mathrm{O}$ ranged from -4.94 per mil in well $\mathrm{NC} 1$ to -3.66 per mil in well WC4 (fig. 3; appendix 1). The relation between the isotopic ratios ${ }^{87 / 86} \mathrm{Sr}$ and ${ }^{11 / 10} \mathrm{~B}$ in the 2004 Carrizo samples is shown in figure 4 . Well NC5 is excluded from this plot because no value for ${ }^{11 / 10} \mathrm{~B}$ was measured for the sample collected at this well. The ${ }^{87 / 86} \mathrm{Sr}$ ratios ranged from 0.70786 in well EC3 to 0.71263 in well NC2 and the ${ }^{11 / 10} \mathrm{~B}$ ratios ranged from 4.087 in well EC3 to 4.155 in wells NC2 and NC3. The relation of ${ }^{226} \mathrm{Ra}$ and ${ }^{228} \mathrm{Ra}$ in the 2004 Carrizo samples is shown in figure 5 . The concentration of ${ }^{226} \mathrm{Ra}$ ranged from $0.164 \mathrm{pCi} / \mathrm{L}$ in well EC3 to $1.354 \mathrm{pCi} / \mathrm{L}$ in well $\mathrm{WC} 3$. The concentration of ${ }^{228} \mathrm{Ra}$ ranged from $0.553 \mathrm{pCi} / \mathrm{L}$ in well NC5 to $3.047 \mathrm{pCi} / \mathrm{L}$ in well WC4.

\section{Post-Injection Carrizo Aquifer}

After water from the Edwards aquifer was injected at the ASR site, the quality of groundwater in the Carrizo aquifer was assessed. Samples from all but two Carrizo wells were collected during either 2005 (2005 Carrizo samples) or 2008 (2008 Carrizo samples), or both, and from the Carrizo-Wilcox well during 2005 and 2008. Samples also were collected in July 2008 at four wells at the ASR site (ASR recovery wells) used for recovery of injected water to characterize postinjection water from the Carrizo aquifer. To indicate the extent to which injected Edwards aquifer water might migrate north, three wells on the north side of the ASR site (ASR productiononly wells) designed to pump water from, but not inject water into, the Carrizo aquifer were sampled in July 2008.

\section{Major-Ion Chemistry}

With only a few exceptions, major-ion concentrations in post-injection groundwater (2005 and 2008 Carrizo samples) were similar to concentrations in pre-injection groundwater (2004 Carrizo samples) (fig. 6). Slightly larger sulfate 
A

B

2004 Carrizo samples

2005 Carrizo samples

C

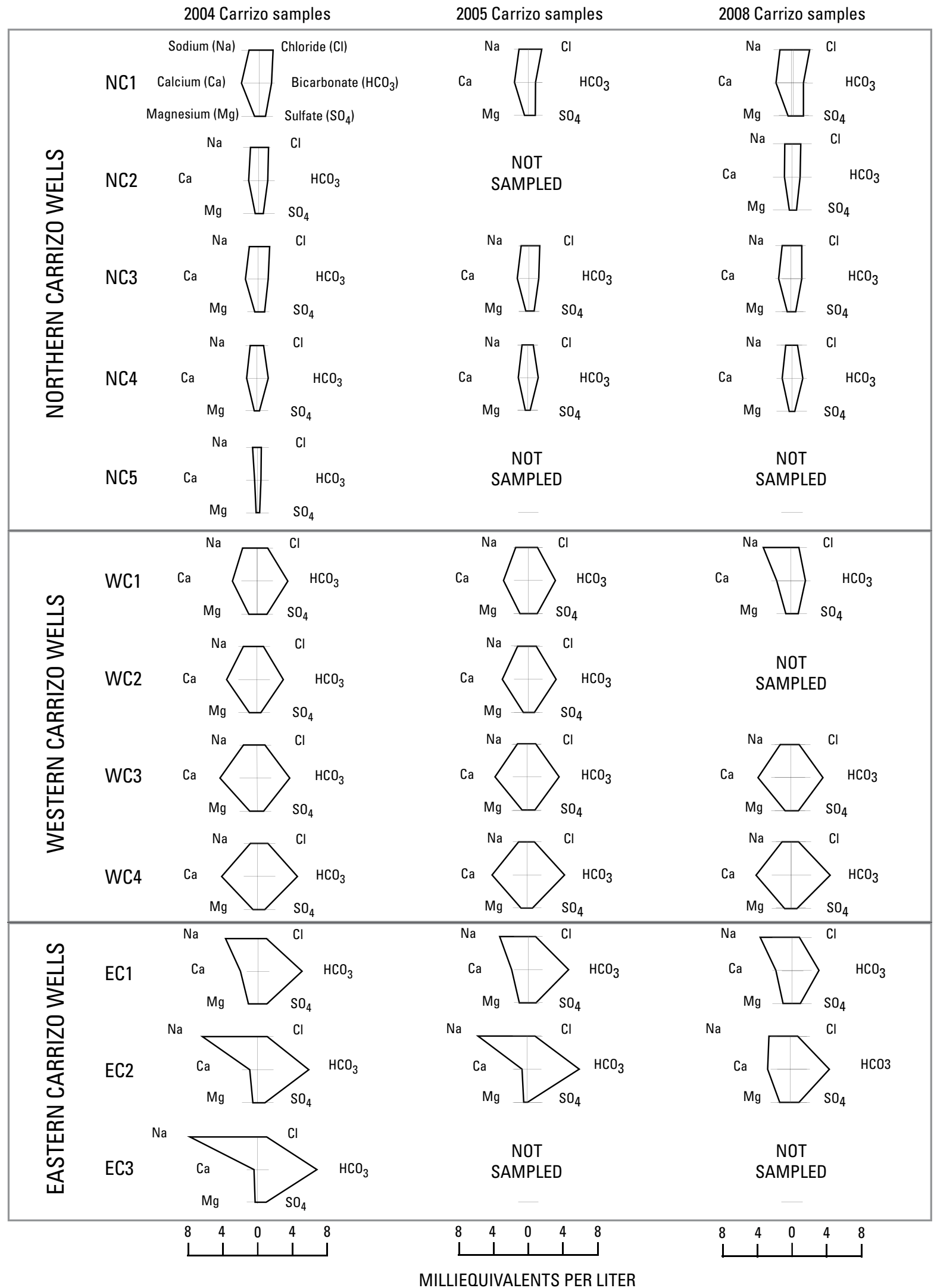

Figure 6. Concentrations of selected cations and anions for wells screened in the Carrizo aquifer in northeastern Atascosa and western Wilson Counties, Texas (A) 2004 Carrizo samples, (B) 2005 Carrizo samples, and (C) 2008 Carrizo samples. 
Table 3. Dissolved iron and dissolved manganese concentrations from 11 wells sampled in northeastern Atascosa and western Wilson Counties, Texas, 2004-08, with percent difference between 2005 or 2008 concentrations and 2004 concentration.

[USGS, U.S. Geological Survey; $\mu \mathrm{g} / \mathrm{L}$, micrograms per liter; --, not applicable]

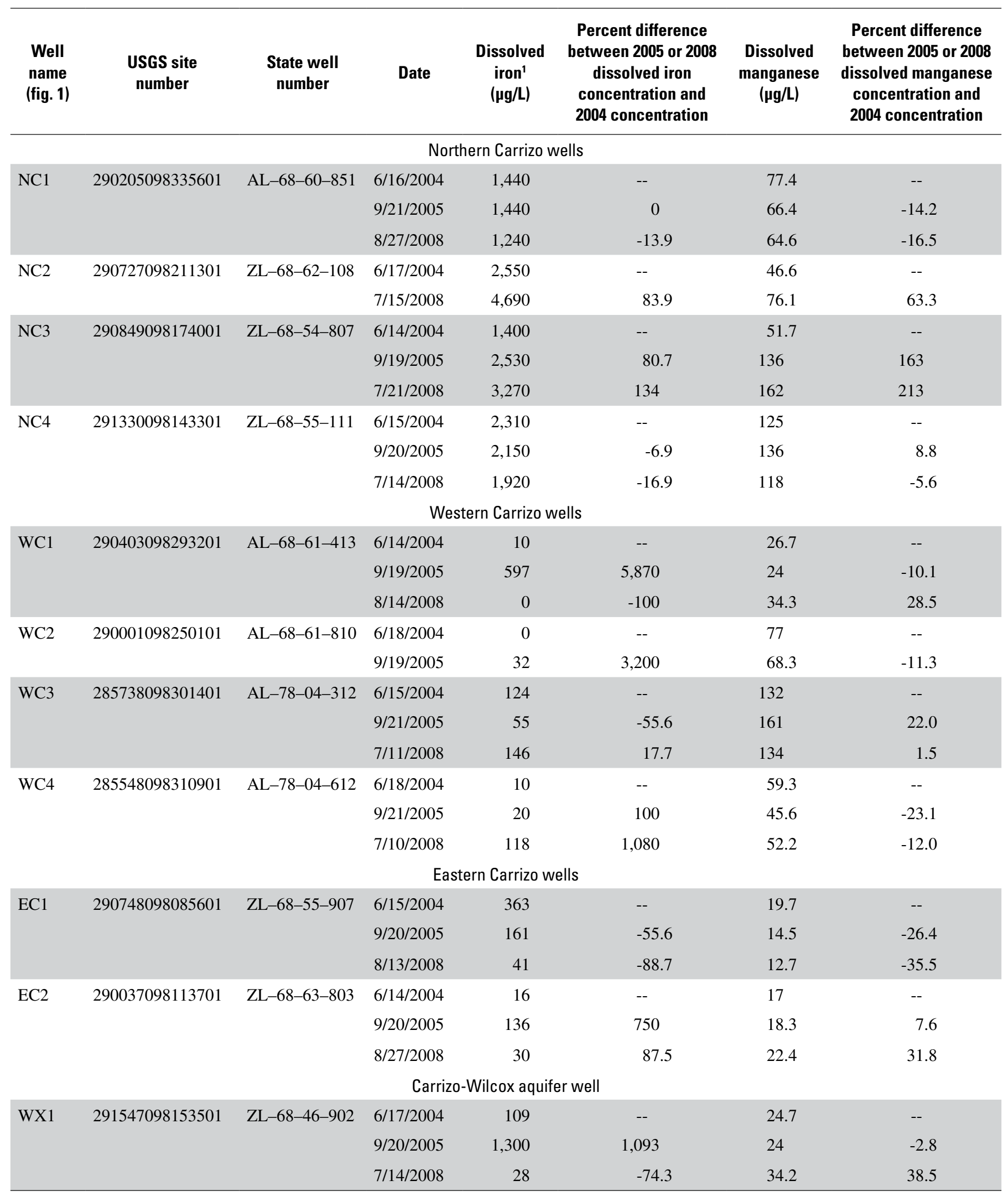

\footnotetext{
${ }^{1}$ Nondetections considered zero for percent difference computation.
} 
concentrations and slightly smaller bicarbonate concentrations were measured in samples collected from well NC1 in 2005 and 2008 compared to the sulfate and bicarbonate concentrations measured in the sample collected from this well in 2004. Well WC1 had a larger sodium concentration and smaller calcium, magnesium, bicarbonate, and sulfate concentrations in the 2008 sample compared to those concentrations in the 2004 or 2005 samples collected from this well. Larger calcium and magnesium concentrations and a smaller sodium concentration were measured in samples collected in 2008 from well EC2 compared to the concentrations measured in samples collected from this well in 2004 and 2005. Additional temporal samples would be necessary to determine whether these fluctuations in major-ion chemistry indicate an influence from the ASR operations on groundwater quality because the chemistry of the Carrizo aquifer naturally might vary spatially in the study area.

The major-ion chemistry for samples collected in May 2005 from the Edwards aquifer source wells, ASR injection well, and Carrizo aquifer monitoring wells and for samples collected in July 2008 from the ASR recovery wells and ASR production-only wells is represented by a trilinear diagram (fig. 7). Larger chloride and sodium concentrations and smaller bicarbonate concentrations were measured in samples collected from the Carrizo aquifer monitoring wells compared to samples collected from the Edwards-aquifer source wells and ASR injection well. The samples collected from the four ASR recovery wells were similar in major-ion chemistry compared to samples collected from the Edwards aquifer source wells and ASR injection well. The similarity could indicate that as Edwards aquifer water was injected, it displaced native Carrizo aquifer water, or alternatively, if mixing of Edwards and Carrizo aquifer waters was occurring, the major-ion signature for the Carrizo aquifer water might have been obscured by the signature of the injected Edwards aquifer water. The ASR production-only wells were 0.75 to 1.25 miles from the nearest ASR recovery well. Larger concentrations of sodium and chloride and smaller concentrations of bicarbonate were measured in samples collected from the ASR productiononly wells compared to those concentrations in samples collected from the ASR recovery wells. Because the open intervals and pump depths for all seven wells (four ASR recovery

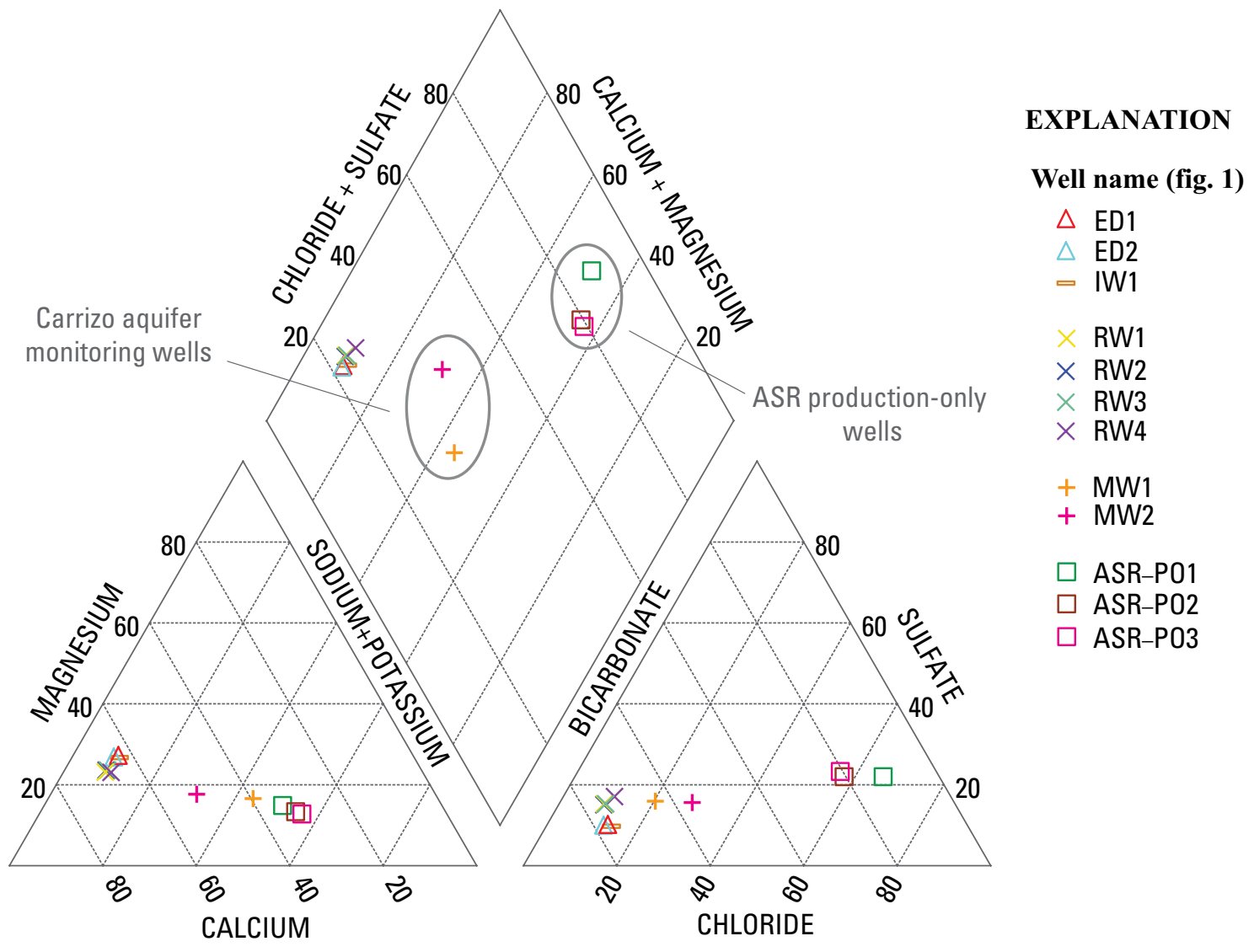

PERCENT MILLIEQUIVALENTS

Figure 7. Trilinear diagram showing composition of Edwards aquifer water injected at an aquifer storage and recovery (ASR) site, May 2005, and composition of water recovered from ASR site, July 2008, southern Bexar County, Texas. 
wells and three ASR production-only wells) that samples were collected from in July 2008 are within approximately the same interval (table 1), the differences in major-ion chemistry might indicate that Edwards aquifer water being injected at the ASR site did not migrate north after entering the Carrizo aquifer by July 2008.

\section{Trace-Element Chemistry}

Dissolved iron concentrations in the 2005 Carrizo samples ranged from $20 \mu \mathrm{g} / \mathrm{L}$ in well WC4 to $2,530 \mu \mathrm{g} / \mathrm{L}$ in well NC3; dissolved manganese concentrations ranged from $14.5 \mu \mathrm{g} / \mathrm{L}$ in well EC1 to $161 \mu \mathrm{g} / \mathrm{L}$ in well WC3. Dissolved iron concentrations in the 2008 Carrizo samples ranged from less than $8 \mu \mathrm{g} / \mathrm{L}$ (LRL) in well WC1 to $4,690 \mu \mathrm{g} / \mathrm{L}$ in well NC2; dissolved manganese concentrations ranged from $12.7 \mu \mathrm{g} / \mathrm{L}$ in well EC1 to $162 \mu \mathrm{g} / \mathrm{L}$ in well NC3. The percent difference (PD) between the post-injection concentration (2005 or 2008 Carrizo sample) and the pre-injection concentration (2004 sample) was computed using the equation

$$
\mathrm{PD}=\left(\left(\mathrm{C}_{1}-\mathrm{C}_{3}\right) / \mathrm{C}_{3}\right) \times 100
$$

where

$$
\begin{gathered}
C_{1}=2005 \text { or } 2008 \text { concentration from environmental } \\
\text { sample; and } \\
C_{3}=2004 \text { concentration from environmental sample. }
\end{gathered}
$$

The dissolved iron PDs for the 2005 Carrizo samples ranged from a 55.6-percent decrease in wells WC3 and EC1 to a 5,870-percent increase in well WC1. The dissolved manganese PDs for the 2005 Carrizo samples ranged from a 26.4-percent decrease in well EC1 to a 163-percent increase in well NC3. No spatial patterns were observed in PDs for either dissolved iron or dissolved manganese concentrations for the study area in 2005.

The dissolved iron PDs for the 2008 Carrizo samples ranged from a 100-percent decrease in well WC1 to a 1,080-percent increase in well WC4. Dissolved iron PDs were positive for both 2005 and 2008 Carrizo samples in wells NC3, WC4, and EC2 and negative for both 2005 and 2008 Carrizo samples in wells NC4 and EC1. The dissolved manganese PDs for the 2008 Carrizo samples ranged from a 35.5-percent decrease in well EC1 to a 213-percent increase in well NC3. Dissolved manganese PDs were positive for both 2005 and 2008 Carrizo samples in wells NC3, WC3, and EC2 and negative for both 2005 and 2008 Carrizo samples in wells $\mathrm{NC} 1, \mathrm{WC} 4$, and EC1. The changes in dissolved iron and dissolved manganese concentrations cannot be attributed to ASR operations with the small amount of data collected for this study.

Larger dissolved iron and dissolved manganese concentrations, in general, were measured in the samples collected from the Carrizo aquifer compared to those concentrations in samples collected from the Edwards aquifer. The Carrizo aquifer monitoring wells (MW1 and MW2) produced water with dissolved iron concentrations of 95 and 6,020 $\mu \mathrm{g} / \mathrm{L}$, respectively, and dissolved manganese concentrations of 15.1 and $124 \mu \mathrm{g} / \mathrm{L}$, respectively (appendix 1). In the ASR recovery wells dissolved iron concentrations ranged from $5 \mu \mathrm{g} / \mathrm{L}$ (estimated) in well RW1 to $279 \mu \mathrm{g} / \mathrm{L}$ in well RW4 and dissolved manganese concentrations ranged from $5.8 \mu \mathrm{g} / \mathrm{L}$ in well RW2 to $15.8 \mu \mathrm{g} / \mathrm{L}$ in well RW4, consistently larger than those concentrations in the samples collected from the Edwards aquifer source wells. These data indicate that after the Edwards aquifer source water was injected at the ASR site, it might have mixed with the native Carrizo aquifer; a mix of water from both aquifers would explain the dissolved iron and dissolved manganese concentrations that are different from those concentrations in either the native Carrizo aquifer water or the Edwards aquifer water. Another possibility is that Edwards aquifer water displaced Carrizo aquifer water as it was injected, and water from the Edwards aquifer dissolved the iron and manganese directly from the Carrizo Sand, which has naturally large iron and manganese concentrations (Pearson and White, 1967). Dissolved iron concentrations in the ASR production-only wells ranged from $373 \mu \mathrm{g} / \mathrm{L}$ in well ASR-PO2 to $683 \mu \mathrm{g} / \mathrm{L}$ in well ASR-PO1 and dissolved manganese concentrations ranged from $9.2 \mu \mathrm{g} / \mathrm{L}$ in well ASR-PO3 to $25.4 \mu \mathrm{g} / \mathrm{L}$ in well ASR-PO1. Similar to the observation for major-ion chemistry, the trace-element chemistry also appears to indicate that the injected Edwards aquifer source water did not migrate north by July 2008 .

\section{Isotopes}

For the 2008 Carrizo samples, $\delta$ D ranged from -28.01 per mil in well NC1 to -20.59 per mil in well $\mathrm{WC} 4$ and $\delta^{18} \mathrm{O}$ ranged from -4.97 per mil in well NC4 to -3.74 per mil in well WC4 (fig. 3; appendix 1). No substantial differences in either $\delta \mathrm{D}$ or $\delta^{18} \mathrm{O}$ were observed between the 2004 and 2008 Carrizo samples, indicating that the Edwards aquifer source water did not affect the isotope chemistry of the native Carrizo aquifer water in the 2008 Carrizo samples.

In the graph showing the relation between $\delta \mathrm{D}$ and $\delta^{18} \mathrm{O}$ (fig. 3), all but one 2008 Carrizo sample plotted below the LMWL calculated by Otero (2007), indicating that the lighter water molecules were preferentially removed, by various amounts of evaporation, from the precipitation before any of it entered the Carrizo aquifer as recharge. Similarities in $\delta D$ and $\delta^{18} \mathrm{O}$ in samples collected from the Edwards aquifer source wells, ASR injection well, and ASR recovery wells indicate little change in isotopic composition between the time of injection and the time of recovery, supporting the premise that the injected Edwards aquifer source water displaced native water in the Carrizo aquifer as it was injected. The differences in the isotopic ratios of the Edwards aquifer source wells, ASR injection well, and ASR recovery wells compared to those in the ASR production-only wells again indicate that the source water, once injected, did not migrate north in the subsurface by July 2008. The isotopic ratios from the Carrizo aquifer monitoring well samples were more similar to those from the ASR production-only well samples than from the Edwards 
aquifer source water samples. However, the isotopic ratios from Carrizo aquifer monitoring well MW2, closest to the zone of injection, are heavier than the isotopic ratios from Carrizo aquifer monitoring well MW1 or from the ASR production-only wells (fig. 3). The pattern observed in the isotopic ratios indicates there might be some mixing of native Carrizo aquifer water with Edwards aquifer source water.

For the 2008 Carrizo samples, ${ }^{87 / 86} \mathrm{Sr}$ ratios ranged from 0.70825 in well EC1 to 0.71283 in well NC2 and ${ }^{11 / 10} \mathrm{~B}$ ratios ranged from 4.110 in well EC1 to 4.172 in well NC3 (fig. 4; appendix 1). The smallest ${ }^{11 / 10} \mathrm{~B}$ ratio (4.092) of all wells sampled in the study area during 2008 was in the sample from well WX1, the well later determined to be partially screened in the Carrizo-Wilcox aquifer. Compared to the 2004 Carrizo samples and the Edwards aquifer source well samples, no substantial change in ${ }^{87 / 86} \mathrm{Sr}$ and ${ }^{11 / 10} \mathrm{~B}$ ratios were observed in the 2008 Carrizo samples, again indicating that the Edwards aquifer source water has not affected the isotope chemistry of the native Carrizo aquifer water post-injection by July 2008 .

Samples collected from the ASR recovery wells produced ${ }^{8786} \mathrm{Sr}$ ratios that ranged from 0.70780 in wells RW1 and RW3 to 0.70802 in well RW4 and ${ }^{11 / 10} \mathrm{~B}$ ratios that ranged from 4.136 in well RW1 to 4.151 in well RW2. These ratios are comparable to the ratios for the Edwards aquifer source wells and the ASR injection well, indicating no substantial change occurred in these isotopic ratios as the water was stored in the subsurface. In contrast, ${ }^{87 / 86} \mathrm{Sr}$ and ${ }^{11 / 10} \mathrm{~B}$ ratios for samples collected from ASR production-only wells were substantially different from ${ }^{87 / 86} \mathrm{Sr}$ and ${ }^{11 / 10} \mathrm{~B}$ ratios for samples collected from ASR recovery wells, providing additional evidence that the injected Edwards aquifer source water did not migrate north by July 2008 (fig. 4).

The smallest ${ }^{226} \mathrm{Ra}$ concentration of all wells sampled in the study area during 2008 was $0.327 \mathrm{pCi} / \mathrm{L}$ in well WX1, which is partially screened in the Carrizo-Wilcox aquifer. ${ }^{226} \mathrm{Ra}$ concentrations in the 2008 Carrizo samples ranged from $0.402 \mathrm{pCi} / \mathrm{L}$ in well NC3 to $1.580 \mathrm{pCi} / \mathrm{L}$ in well $\mathrm{WC} 4$, whereas ${ }^{228} \mathrm{Ra}$ concentrations ranged from $0.829 \mathrm{pCi} / \mathrm{L}$ in well NC3 to $3.690 \mathrm{pCi} / \mathrm{L}$ in well WC4 (fig. 5; appendix 1). Although ${ }^{226} \mathrm{Ra}$ concentrations are mostly larger in 2008 Carrizo samples compared to ${ }^{226} \mathrm{Ra}$ concentrations in 2004 Carrizo samples, there does not appear to be a consistent shift in the plotted positions of ${ }^{226} \mathrm{Ra}$ and ${ }^{228} \mathrm{Ra}$ concentrations in the 2008 Carrizo samples toward the plotted positions of ${ }^{226} \mathrm{Ra}$ and ${ }^{228} \mathrm{Ra}$ concentrations measured in samples from either Edwards aquifer source wells or ASR recovery wells. The distinction between ${ }^{226} \mathrm{Ra}$ and ${ }^{228} \mathrm{Ra}$ concentrations in Carrizo aquifer samples from those in Edwards aquifer source water samples provides additional evidence that Edwards aquifer source water has not affected the concentration of radium isotopes in the Carrizo aquifer near the ASR site.

${ }^{226} \mathrm{Ra}$ concentrations in samples collected from the ASR recovery wells ranged from $0.277 \mathrm{pCi} / \mathrm{L}$ in well RW2 to $0.344 \mathrm{pCi} / \mathrm{L}$ in well RW3 (appendix 1 ); ${ }^{228} \mathrm{Ra}$ concentrations were not detected in the ASR recovery wells. Ranges in concentrations of ${ }^{226} \mathrm{Ra}$ and ${ }^{228} \mathrm{Ra}$ in the Edwards aquifer source wells and in the ASR injection well were similar. The concentrations of ${ }^{226} \mathrm{Ra}$ and ${ }^{228} \mathrm{Ra}$ in the samples collected at all four ASR recovery wells were noticeably smaller than the concentrations in samples collected from the Edwards aquifer source wells and the ASR injection well. The half-life of ${ }^{226} \mathrm{Ra}$ is approximately 1,600 years (Wieser, 2005); therefore, the smaller ${ }^{226} \mathrm{Ra}$ concentrations indicate that some mixing of the Edwards aquifer water and the Carrizo aquifer water might have occurred in the subsurface after the source water had been injected. Carrizo aquifer monitoring wells MW1 and MW2 produced water with ${ }^{226} \mathrm{Ra}$ concentrations of 0.419 and $0.672 \mathrm{pCi} / \mathrm{L}$, respectively, and ${ }^{228} \mathrm{Ra}$ concentrations of 0.987 and $1.352 \mathrm{pCi} / \mathrm{L}$, respectively. The ASR production-only wells produced water with ${ }^{226} \mathrm{Ra}$ concentrations that ranged from $0.374 \mathrm{pCi} / \mathrm{L}$ in well ASR-PO3 to $0.619 \mathrm{pCi} / \mathrm{L}$ in well ASR$\mathrm{PO} 1$ and ${ }^{228} \mathrm{Ra}$ concentrations that ranged from $1.080 \mathrm{pCi} / \mathrm{L}$ in well ASR-PO2 to $1.450 \mathrm{pCi} / \mathrm{L}$ in well ASR-PO1. Concentrations of ${ }^{226} \mathrm{Ra}$ and ${ }^{228} \mathrm{Ra}$ in samples from the Carrizo aquifer monitoring wells and the ASR production-only wells were within a similar range indicating that the wells might have been producing from a single water source that differed from the water source for the Edwards aquifer source wells and ASR recovery wells.

\section{Summary}

The U.S. Geological Survey (USGS), in cooperation with the San Antonio Water System (SAWS), did a study during 2004-08 to characterize the quality of native groundwater from the Edwards aquifer and pre- and post-injection water from the Carrizo aquifer (informal name commonly applied to the upper part of the Carrizo-Wilcox aquifer in the area) at and near an aquifer storage and recovery (ASR) site in Bexar, Atascosa, and Wilson Counties, Tex. Findings of the study are intended to provide a better understanding of possible changes in the quality of groundwater near an active ASR site that might result from the mixing of water from different aquifers. Possible iron and manganese mobilization, caused by changes in reduction-oxidation (redox) reaction conditions in an aquifer that might occur when non-native water is introduced to the aquifer, was a concern at the ASR site.

Groundwater samples were collected and analyzed for selected physical properties and constituents to characterize the quality of native groundwater from the Edwards aquifer and pre- and post-injection water from the Carrizo aquifer near the ASR site. Water-chemistry and isotope data were analyzed to evaluate the quality of water in the Carrizo aquifer prior to and after water from the Edwards aquifer was injected at the ASR site. Water-chemistry and isotope data also were used to evaluate whether any change in water-chemistry or isotope composition occurred in the Edwards aquifer source water as it was transferred through a 38-mile pipeline to the ASR site. Groundwater sampling was done four times during the study. Water-quality constituent concentrations and physical properties were measured in May 2005 in samples collected from 
the Edwards aquifer source wells. Groundwater-chemistry and isotope data also were measured in samples collected in May 2005 at the wellhead of an ASR injection well, which is screened in the Carrizo aquifer at the ASR site and used for injecting water from the Edwards aquifer source wells into the Carrizo aquifer. Pre-injection Carrizo aquifer water was characterized by analyzing samples collected from 12 wells (2004 Carrizo wells) screened in the Carrizo aquifer near the ASR site. Samples from these wells were collected in June 2004 before injection of Edwards aquifer water into the Carrizo aquifer. Post-injection Carrizo aquifer water near the ASR site was characterized after injection of Edwards aquifer water began at the ASR site. Water-quality samples were collected in September 2005 (2005 Carrizo wells) and during July-August 2008 (2008 Carrizo wells) at selected subsets of the 2004 Carrizo wells. Two Carrizo aquifer monitoring wells at and near the ASR site completed in the Carrizo aquifer were sampled in May 2005. To characterize post-injection water from the Carrizo aquifer, samples also were collected in July 2008 at four wells (ASR recovery wells) at the ASR site used to recover injected water. To indicate the extent to which injected Edwards aquifer water might migrate north, three wells (ASR production-only wells) on the north side of the ASR site, designed to pump water from but not inject water into the Carrizo aquifer, were sampled in July 2008. Waterquality data also were collected from two stormwater sampling sites near the ASR site to identify surface-water contaminants, if any, that potentially could enter the Carrizo aquifer through recharge. Because only eight stormwater samples (representing five storms) could be collected, the stormwater analytical data were included in the appendix but not assessed in the report.

Geochemical and isotope data from the samples collected from the Edwards aquifer source wells and the ASR injection well indicate no substantial changes in major-ion, trace-element, and isotope chemistry occurred as the water was transferred through a 38-mile pipeline from the Edwards aquifer source wells to the ASR injection well. Geochemical and isotope data from the Edwards aquifer source wells, ASR injection well, and ASR recovery wells were graphically analyzed to help evaluate in a preliminary way if water in the Carrizo aquifer had undergone any chemical changes after Edwards aquifer source water was injected at the ASR site. Only minor differences in major-ion and stable isotope chemistry measured in samples collected from the Edwards aquifer source wells, ASR injection well, and the four ASR recovery wells were observed. The samples collected from the four ASR recovery wells were similar in major-ion and stable isotope chemistry compared to the samples collected from the Edwards aquifer source wells and the ASR injection well. The similarity could indicate that as Edwards aquifer water was injected, it displaced native Carrizo aquifer water or, alternatively, if mixing of Edwards and Carrizo aquifer waters was occurring, the major-ion and stable isotope signatures for the Carrizo aquifer water might have been obscured by the signatures of the injected Edwards aquifer water. Dissolved iron and dissolved manganese concentrations in samples collected from the ASR recovery wells were consistently larger than those in the samples collected from the Edwards aquifer source wells. These data indicate that after the Edwards aquifer source water was injected at the ASR site, it might have mixed with the native Carrizo aquifer; a mix of water from both aquifers would explain the dissolved iron and dissolved manganese concentrations that are different from those in either the native Carrizo aquifer water or the Edwards aquifer water. Another possibility is that Edwards aquifer water displaced Carrizo aquifer water as it was injected, and water from the Edwards aquifer dissolved the iron and manganese directly from the Carrizo Sand, which has naturally large iron and manganese concentrations. Concentrations of Ra-226 and Ra-228 in the Edwards aquifer source wells and ASR injection well were within a similar range. The concentrations of Ra-226 and Ra-228 in the samples collected at all four ASR recovery wells were noticeably smaller than the concentrations in samples collected from the Edwards aquifer source wells and from the ASR injection well. The half-life of Ra-226 is approximately 1,600 years; therefore the smaller Ra-226 concentrations indicate that some mixing of the Edwards aquifer water and the Carrizo aquifer water might have occurred in the subsurface after the source water had been injected.

Geochemical and isotope data measured in samples collected from the Carrizo aquifer monitoring wells and the ASR production-only wells were graphically analyzed with the Edwards aquifer source wells, ASR injection well, and ASR recovery wells to determine the extent injected Edwards aquifer water might have migrated to the south by May 2005 and to the north by July 2008. The distinctness of the majorion, trace-element, and isotope data collected from the Carrizo aquifer monitoring wells and ASR production-only wells in relation to the data collected from the Edwards aquifer source wells, ASR injection well, and ASR recovery wells indicates that injected Edwards aquifer water had not migrated either to the monitoring wells located in the southern section of the ASR site and south of the ASR site by May 2005 or to the ASR production-only wells located in the northern section of the ASR site by July 2008.

Geochemical and isotope data measured from samples collected from the 2004 Carrizo wells, 2005 Carrizo wells, and 2008 Carrizo wells were graphically analyzed to determine if any changes in chemistry could be discerned. Major-ion, traceelement, and isotope chemistry varied spatially in the samples collected from the Carrizo aquifer. The northern Carrizo wells (wells NC1, NC2, NC3, NC4, and NC5, in the northern part of the study area) produced water with small major-ion concentrations. The western Carrizo wells (wells WC1, WC2, WC3, and $\mathrm{WC} 4$, in the western part of the study area) produced water with relatively large calcium concentrations compared to water sampled from the other wells in the study area. The eastern Carrizo wells (wells EC1, EC2 and EC3 in the southeastern part of the study area) contained water with relatively large sodium and bicarbonate concentrations. With the exception of a few samples, major-ion concentrations measured in samples 
collected from Carrizo aquifer wells in 2004, 2005, and 2008 were similar. A slightly larger sulfate concentration and a slightly smaller bicarbonate concentration were measured in samples collected in 2005 and 2008 from well NC1 compared to samples collected at well NC1 in 2004. Larger sodium concentrations and smaller calcium, magnesium, bicarbonate, and sulfate concentrations were measured in samples collected in 2008 from well WC1 than in samples collected at this well in 2004 and 2005. Larger calcium and magnesium concentrations and a smaller sodium concentration were measured in the samples collected in 2008 at well EC2 compared to samples collected at this well in 2004 and 2005. While in some cases the computed percent difference (compared to concentrations from June 2004) in dissolved iron and dissolved manganese concentrations in 11 wells sampled in the Carrizo aquifer in 2005 and 2008 were quite large, no trends that might have been caused by migration of injected Edwards aquifer water were observed. Because of the variation in geochemical data in the Carrizo aquifer, differences in major-ion and traceelement data between the three sampling periods cannot be directly attributed to the ASR site operations using the small data set collected for this study. No appreciable difference in isotope data from 2004 and 2008 Carrizo wells were discerned, indicating that the Edwards aquifer source water might not have affected the isotope chemistry of the native Carrizo aquifer water near the sampled Carrizo wells by July 2008 .

\section{References}

Ashworth, J.B., and Hopkins, Janie, 1995, Aquifers of Texas: Texas Water Development Board Report 345, 69 p.

Basu, Rituparna, Haque, S.E., Tang, Jianwu, Ji, Junfeng, and Johannesson, K.H., 2007, Evolution of selenium concentrations and speciation in groundwater flow systems-Upper Floridan (Florida) and Carrizo Sand (Texas) aquifers: Chemical Geology, v. 246, no. 3-4, p. 147-169, accessed December 17, 2009, at http://www.sciencedirect.com/ science?_ob=ArticleURL\&_udi=B6V5Y-4PVPVTF-1\&_ user $=696292 \&$ \&coverDate $=12 \% 2 F 30 \% 2 F 2007 \& \_r d o c=$ $1 \& \_f m t=h i g h \& \_o r i g=s e a r c h \& \_s o r t=d \& \_d o c a n c h o r=$ $\&$ view $=c \&$ \&acct $=C 000038819 \&$ \&ersion $=1 \&$ \&rlVersion $=$ $0 \& \_u s e r i d=696292 \& m d 5=0 b 6 c c e 4 c f 353 f 6482 c 8 e c 77 a 00 a$ $58 d f b$.

Bayless, E.R., Bullen, T.D., and Fitzpatrick, J.A., 2004, Use of ${ }^{87} \mathrm{Sr} /{ }^{86} \mathrm{Sr}$ and $\delta^{11} \mathrm{~B}$ to identify slag-affected sediment in southern Lake Michigan: Environmental Science and Technology, v. 38, no. 5, p. 1,330-1,337.

Bruckner, M.Z., 2009, A primer on stable isotopes and some common uses in hydrology: Bozeman, Mont., Montana State University, accessed November 12, 2009, at http://serc.carleton.edu/microbelife/research_methods/ environ_sampling/stableisotopes.html.
Castro, M.C., and Goblet, Patrick, 2003, Calibration of regional groundwater flow models-Working toward a better understanding of site specific systems: Water Resources Research, v. 39, no. 6, p. 1,172.

Castro, M.C., Stute, Martin, and Schlosser, Peter, 2000, Comparison of ${ }^{4} \mathrm{He}$ ages and ${ }^{14} \mathrm{C}$ ages in simple aquifer systems-Implications for groundwater flow and chronologies: Applied Geochemistry, v. 15, p. 1,137-1,167.

Catanzaro, E.J., Champion, C.E., Garner, E.L., Malinenko, G., Sappenfield, K.M., and Shields, W.R., 1970, Boric acid-Isotope and assay standard reference materials: U.S. National Bureau of Standards, Special Publication No. 260-17.

Childress, C.J.O., Foreman, W.T., Connor, B.F., and Maloney, T.J., 1999, New reporting procedures based on long-term method detection levels and some considerations for interpretations of water-quality data provided by the U.S. Geological Survey National Water Quality Laboratory: U.S. Geological Survey Open-File Report 99-193, 19 p.

Clark, I.D., and Fritz, Peter, 1997, Environmental isotopes in hydrogeology: Boca Raton, Fla., CRC Press, 328 p.

Coplen, T.B., Wildman, J.D., and Chen, J., 1991, Improvements in the gaseous hydrogen-water equilibration technique for hydrogen isotope ratio analysis: Analytical Chemistry, v. 63, p. 910-912.

Craig, H., 1961, Isotopic variation in meteoric water: Science, v. 133. p. 1,702-1,703.

Davidson, G.R., and Bassett, R.L., 1993, Application of boron isotopes for identifying contaminants such as fly ash leachate in groundwater: Environmental Science and Technology, v. 27 , no. 1 , p. $172-176$.

Edwards Aquifer Authority, 2009, Edwards Aquifer Authority Act: accessed March 25, 2010 at http://www. edwardsaquifer.org/pdfs/EAAact.pdf.

Epstein, S., and Mayeda, T., 1953, Variation of $\mathrm{O}^{18}$ content of waters from natural sources: Geochimica et Cosmochimica Acta, v. 4, p. 213-224.

Fahlquist, Lynne, and Ardis, A.F., 2004, Quality of water in the Trinity and Edwards aquifers, south-central Texas, 1996-98: U.S. Geological Survey Scientific Investigations Report 2004-5201, 17 p.

Fishman, M.J., ed., 1993, Methods of analysis by the U.S. Geological Survey National Water Quality LaboratoryDetermination of inorganic and organic constituents in water and fluvial sediments: U.S. Geological Survey OpenFile Report 93-125, 217 p.

Fishman, M.J., and Friedman, L.C., eds., 1989, Methods for determination of inorganic substances in water and fluvial 
sediments: U.S. Geological Survey Techniques of WaterResources Investigations, book 5, chap. A1, 545 p.

Focazio, M.J., Szabo, Zoltan, Kraemer, T.F., Mullin, A.H., Barringer, T.H., and dePaul, V.T., 2001, Occurrence of selected radionuclides in ground water used for drinking water in the United States-A targeted reconnaissance survey, 1998: U.S. Geological Survey Water-Resources Investigations Report 00-4273, 39 p.; available at http://pubs.usgs.gov/wri/wri004273/pdf/wri004273.pdf.

Fritz, Peter, and Fontes, J.C., eds., 1980, Handbook of environmental isotope geochemistry, v. 1-The terrestrial environment: Amsterdam, Elsevier, 545 p.

Garbarino, J.R., 1999, Methods of analysis by the U.S. Geological Survey National Water Quality LaboratoryDetermination of dissolved arsenic, boron, lithium, selenium, strontium, thallium, and vanadium using inductively coupled plasma-mass spectrometry: U.S. Geological Survey Open-File Report 99-093, 31 p.

Garbarino, J.R., Kanagy, L.K., and Cree, M.E., 2006, Determination of elements in natural-water, biota, sediment and soil samples using collision/reaction cell inductively coupled plasma-mass spectrometry: U.S. Geological Survey Techniques and Methods 5-B1, $87 \mathrm{p}$.

Garbarino, J.R., and Struzeski, T.M., 1998, Methods of analysis by the U.S. Geological Survey National Water Quality Laboratory-Determination of elements in whole-water digests using inductively coupled plasma-optical emission spectrometry and inductively coupled plasma-mass spectrometry: U.S. Geological Survey Open-File Report 98-165, $101 \mathrm{p}$.

Garbarino, J.R., and Taylor, H.E., 1996, Inductively coupled plasma-mass spectrometric method for the determination of dissolved trace elements in natural water: U.S. Geological Survey Open-File Report 94-358, 49 p.

Haque, Shama, and Johannesson, K.H., 2006, Arsenic concentrations and speciation along a groundwater flow pathThe Carrizo Sand aquifer, Texas, USA: Chemical Geology v. 228 , no. $1-3$, p. $57-71$.

Harter, Thomas, 2003, Water well design and construction: University of California, Division of Agriculture and Natural Resources Publication 8086 (Farm Water Quality Planning Reference Sheet 11.3), 6 p., accessed March 16, 2010, at http://groundwater.ucdavis.edu/Publications/ Harter_FWQFS_8086.pdf.

Heilweil, V.M., Ortiz, Gema, and Susong, D.D., 2009, Assessment of managed aquifer recharge at Sand Hollow Reservoir, Washington County, Utah, updated to conditions through 2007: U.S. Geological Survey Scientific Investigations Report 2009-5050, 20 p.; available at http://pubs.usgs. gov/sir/2009/5050.
Hem, J.D., 1992, Study and interpretation of the chemical characteristics of natural water (3d ed.): U.S. Geological Survey Water-Supply Paper 2254, $263 \mathrm{p}$.

Inoue, M., and Komura, K., 2007, Preliminary application of low-background gamma-spectrometry to volcanic ground water-Low-levels of ${ }^{7} \mathrm{Be},{ }^{22} \mathrm{Na},{ }^{137} \mathrm{Cs}$ and radium isotopes as new geochemical tracers in a ground water flow system: Journal of Radioanalytical and Nuclear Chemistry, v. 273, no. 1, p. 177-181, accessed March 16, 2010, at http://www. springerlink.com/content/f2611pul636k2u48/.

Kendall, Carol, and Caldwell, E.A., 1998, Fundamentals of isotope geochemistry, chapter 2, in Kendall Carol, and McDonnell, J.J., eds., Isotope tracers in catchment hydrology: Amsterdam, Elsevier, p. 51-86.

Kendall, Carol, and McDonnell, J.J., eds., 1998, Isotope tracers in catchment hydrology: Elsevier, 839 p.

Klemt, W.B., Duffin, G.L., and Elder, G.R., 1976, Groundwater resources of the Carrizo aquifer in the Winter Garden area of Texas: Texas Water Development Board Report 210, v. $1,73 \mathrm{p}$.

Lambert, R.B., Grimm, K.C., and Lee, R.W., 2000, Hydrogeology, hydrologic budget, and water chemistry of the Medina Lake area, Texas: U.S. Geological Survey WaterResources Investigations Report 00-4148, 182 p.

Maclay, R.W., 1995, Geology and hydrology of the Edwards aquifer in the San Antonio area, Texas: U.S. Geological Survey Water-Resources Investigations Report 95-4186, $64 \mathrm{p}$.

Maclay, R.W., and Small, T.A., 1984, Carbonate geology and hydrology of the Edwards aquifer in the San Antonio area, Texas: U.S. Geological Survey Open-File Report 83-537, $72 \mathrm{p}$.

McCurdy, D.E., Garbarino, J.R., and Mullin, A.H., 2008, Interpreting and reporting radiological water-quality data: U.S. Geological Survey Techniques and Methods, book 5, chap. B6, 33 p.

Otero, C.L., 2007, Geologic, hydrologic, and geochemical identification of flow paths in the Edwards aquifer, northeastern Bexar and southern Comal Counties, Texas: U.S. Geological Survey Scientific Investigations Report 20075285, $48 \mathrm{p}$.

Patton, C.J., and Truitt, E.P., 1992, Methods of analysis by the U.S. Geological Survey National Water Quality Laboratory-Determination of total phosphorus by a Kjeldahl digestion method and an automated colorimetric finish that includes dialysis: U.S. Geological Survey Open-File Report 92-146, $39 \mathrm{p}$.

Patton, C.J., and Truitt, E.P., 2000, Methods of analysis by the U.S. Geological Survey National Water Quality Laboratory-Determination of ammonium plus organic nitrogen 
by a Kjeldahl digestion method and an automated photometric finish that includes digest cleanup by gas diffusion: U.S. Geological Survey Open-File Report 00-170, 31 p.

Pearson, F.J., Jr., and White, D.E., 1967, Carbon 14 ages and flow rates of water in Carrizo Sand, Atascosa County, Texas: Water Resources Research, v. 3, no. 1, p. 251-261.

Rose, P.R., 1972, Edwards Group, surface and subsurface, central Texas: Austin, University of Texas, Bureau of Economic Geology Report of Investigations 74, 198 p.

Small, T.A., and Hanson, J.A., 1994, Geologic framework and hydrogeologic characteristics of the Edwards aquifer outcrop, Comal County, Texas: U.S. Geological Survey Water-Resources Investigations Report 94-4117, 10 p.

Smedley, P.L., and Edmunds, M.W., 2002, Redox patterns and trace-element behavior in the East Midlands Triassic Sandstone aquifer, U.K.: Groundwater, v. 40, no. 1, p. 44-58, accessed March 16, 2010, at http://www3.interscience.wiley. com/cgi-bin/fulltext/118907321/PDFSTART.

Stein, W.G., and Ozuna, G.B., 1994, Geologic framework and hydrogeologic characteristics of the Edwards aquifer outcrop, Bexar County, Texas: U.S. Geological Survey WaterResources Investigations Report 95-4030, 8 p.

Stiff, H.A., 1951, The interpretation of chemical water analysis by means of patterns: Journal of Petroleum Technology, v. 3 , p. 15 .
Texas Water Development Board, 2009, TWDB Mapping website-Major aquifers, minor aquifers: accessed January 14, 2009, at http://www.twdb.state.tx.us/mapping/.

U.S. Environmental Protection Agency, 1980, Prescribed procedures for measurement of radioactivity in drinking water: U.S. Environmental Protection Agency, Environmental Monitoring and Support Laboratory, Office of Research and Development, EPA 600-4-80-032, 133 p.

U.S. Geological Survey, variously dated, National field manual for the collection of water-quality data: U.S. Geological Survey Techniques of Water-Resources Investigations, book 9, chaps. A1-A9, accessed November 21, 2009, at http://pubs.water.usgs.gov/twri9A.

U.S. Geological Survey, 2004, Isotope Tracers ProjectResources on isotopes, fundamentals of stable isotope geochemistry: accessed November 12, 2009, at http://wwwrcamnl.wr.usgs.gov/isoig/res/funda.html.

Wershaw, R.L., Fishman, M.J., Grabbe, R.R., and Lowe, L.E., eds., 1987, Methods for the determination of organic substances in water and fluvial sediments: U.S. Geological Survey Techniques of Water-Resources Investigations, book 5, chap. A3, 80 p.

Wieser, M.E., 2005, Atomic weights of the elements 2005: Pure and Applied Chemistry, v. 78, no. 11, p. 2,051-2,066. 
Blank Page 
Appendixes 1-4 
Blank Page 
Appendix 1. Chemical and isotope data from wells sampled at and near an aquifer storage and recovery site, Bexar, Atascosa, and Wilson Counties, Texas, 2004-08.

[NTRU, nephelometric turbidity ratio units; $\mathrm{mg} / \mathrm{L}$, milligrams per liter; $\mu \mathrm{S} / \mathrm{cm}$, microsiemens per centimeter at 25 degrees Celsius; ${ }^{\circ} \mathrm{C}$, degrees $\mathrm{Celsius;} \mathrm{CaCO}_{3}$, calcium carbonate; <, less than; ASR, aquifer storage and recovery; --, not analyzed for or not detected; E, estimated; dup, duplicate; $\mu \mathrm{g} / \mathrm{L}$, micrograms per liter; M, presence verified but not quantified; ${ }^{226} \mathrm{Ra}$, radium-226; pCi/L, picocuries per liter; $\mathrm{PE}$, precision estimate; $\mathrm{ssL}_{\mathrm{C}}$, sample-specific critical level; ${ }^{228} \mathrm{Ra}$, radium-228; ${ }^{87 / 86} \mathrm{Sr}$, strontium-87/strontium-86; ${ }^{11 / 10} \mathrm{~B}$, boron-11/boron- $10 ; \delta^{11} \mathrm{~B}$, delta boron-11; $\delta^{18} \mathrm{O}$, delta oxygen-18; $\delta \mathrm{D}$, delta deuterium; R, nondetection; blue shading, 2004 Carrizo samples; pink shading, 2005 Carrizo samples; green shading, 2008 Carrizo samples]

\begin{tabular}{|c|c|c|c|c|c|c|c|c|c|c|c|c|c|c|c|c|}
\hline $\begin{array}{c}\text { Well } \\
\text { name } \\
\text { (fig. 1) }\end{array}$ & $\begin{array}{l}\text { U.S. Geological } \\
\text { Survey site number }\end{array}$ & $\begin{array}{c}\text { State well } \\
\text { number }\end{array}$ & Date & Time & $\begin{array}{c}\text { Turbid- } \\
\text { ity } \\
\text { (NTRU) }\end{array}$ & $\begin{array}{c}\text { Dis- } \\
\text { solved } \\
\text { oxygen } \\
\text { (mg/L) }\end{array}$ & $\begin{array}{c}\text { pH } \\
\text { (stan- } \\
\text { dard } \\
\text { units) }\end{array}$ & $\begin{array}{c}\text { Specific } \\
\text { conduct- } \\
\text { ance } \\
(\mu \mathrm{S} / \mathrm{cm})\end{array}$ & $\begin{array}{c}\text { Temper- } \\
\text { ature, } \\
\text { water } \\
\left({ }^{\circ} \mathrm{C}\right)\end{array}$ & $\begin{array}{l}\text { Cal- } \\
\text { cium } \\
(\mathrm{mg} / \mathrm{L})\end{array}$ & $\begin{array}{c}\text { Magne- } \\
\text { sium } \\
\text { (mg/L) }\end{array}$ & $\begin{array}{c}\text { Potas- } \\
\text { sium } \\
(\mathrm{mg} / \mathrm{L})\end{array}$ & $\begin{array}{c}\text { So- } \\
\text { dium } \\
\text { (mg/L) }\end{array}$ & $\begin{array}{c}\text { Alkalinity } \\
\text { (mg/L as } \\
\mathrm{CaCO}_{3} \text { ) }\end{array}$ & $\begin{array}{l}\text { Bicar- } \\
\text { bonate } \\
(\mathrm{mg} / \mathrm{L})\end{array}$ & $\begin{array}{c}\text { Car- } \\
\text { bonate } \\
\text { (mg/L) }\end{array}$ \\
\hline \multicolumn{17}{|c|}{ Edwards aquifer source wells } \\
\hline ED1 & 292557098261401 & AY-68-37-508 & $5 / 9 / 2005$ & 1345 & $<2.0$ & 4.9 & 7.3 & 510 & 27.0 & 70.9 & 18.30 & 1.25 & 11.6 & 200 & 243 & $<1$ \\
\hline ED2 & 292643098242101 & AY $-68-37-610$ & $5 / 9 / 2005$ & 1425 & $<2.0$ & 4.7 & 7.3 & 505 & 27.0 & 71.0 & 18.00 & 1.23 & 11.4 & 199 & 242 & $<1$ \\
\hline \multicolumn{17}{|c|}{ ASR injection well } \\
\hline IW1 & 290750098235301 & AY-68-53-912 & $5 / 9 / 2005$ & 1600 & $<2.0$ & 5.9 & 7.5 & 510 & 26.5 & 72.5 & 18.20 & 1.27 & 11.7 & 199 & 241 & $<1$ \\
\hline \multicolumn{17}{|c|}{ Carrizo aquifer monitoring wells } \\
\hline MW1 & 290425098260301 & AL-68-61-505 & $5 / 31 / 2005$ & 1730 & 10 & $<1.0$ & 8.3 & 367 & 27.0 & 28.7 & 7.24 & 13.5 & 28.7 & 113 & 137 & $<1$ \\
\hline MW2 & 290657098242401 & AY $-68-61-321$ & $5 / 12 / 2005$ & 1820 & -- & $<1.0$ & 6.8 & 323 & 26.5 & 28.6 & 6.00 & 6.09 & 16.6 & 78 & 95 & $<1$ \\
\hline \multicolumn{17}{|c|}{ ASR recovery wells } \\
\hline RW1 & 290732098251101 & AY-68-53-811 & $7 / 18 / 2008$ & 0800 & $<2.0$ & 3.1 & 7.1 & 520 & 25.0 & 73.1 & 15.20 & 1.39 & 11.1 & 200 & 243 & $<1$ \\
\hline RW2 & 290751098243101 & AY-68-53-911 & $7 / 18 / 2008$ & 0900 & $<2.0$ & 4.2 & 7.2 & 516 & 24.5 & 70.9 & 15.10 & 1.38 & 10.3 & 200 & 243 & $<1$ \\
\hline RW3 & 290809098232301 & AY-68-53-913 & $7 / 18 / 2008$ & 1100 & $<2.0$ & 3.0 & 7.1 & 515 & 24.5 & 71.8 & 15.40 & 1.42 & 10.6 & 197 & 240 & $<1$ \\
\hline RW4 & 290657098242801 & AY-68-61-319 & $7 / 18 / 2008$ & 1000 & 2.4 & 3.1 & 7.0 & E474 & 25.0 & 62.4 & 13.50 & 2.07 & 11.8 & 169 & 206 & $<1$ \\
\hline \multicolumn{17}{|c|}{ ASR production-only wells } \\
\hline ASR-PO1 & 290841098234001 & AY -68-53-915 & $7 / 28 / 2008$ & 1400 & $<2.0$ & 3.8 & 5.8 & E336 & 25.5 & 19.3 & 4.98 & 7.04 & 28.2 & 18 & 21 & $<1$ \\
\hline ASR-PO2 & 290838098241401 & AY-68-53-916 & $7 / 28 / 2008$ & 1430 & $<2.0$ & 3.7 & 5.8 & E208 & 25.0 & 11.0 & 2.77 & 5.8 & 18.3 & 17 & 21 & $<1$ \\
\hline ASR-PO3 & 290844098243601 & AY-68-53-917 & $7 / 28 / 2008$ & 1500 & $<2.0$ & 3.9 & 5.9 & E212 & 25.0 & 10.6 & 2.72 & 5.67 & 19.4 & 18 & 21 & $<1$ \\
\hline \multicolumn{17}{|c|}{ Northern Carrizo wells } \\
\hline \multirow[t]{3}{*}{$\mathrm{NC} 1$} & 290205098335601 & AL-68-60-851 & $6 / 16 / 2004$ & 1400 & 13 & $<1.0$ & 6.4 & 421 & 28.5 & 38.2 & 5.88 & 7.21 & 25.2 & 68 & E83 & $\mathrm{E}<1$ \\
\hline & & & $9 / 21 / 2005$ & 1130 & $<2.0$ & 1.7 & 5.9 & 416 & 28.0 & 32.5 & 5.23 & 7.37 & 25.0 & 44 & 54 & $<1$ \\
\hline & & & $8 / 27 / 2008$ & 0900 & E1.9 & 3.3 & 6.5 & 462 & 28.0 & 39.3 & 7.07 & 8.59 & 35.1 & 56 & 69 & $<1$ \\
\hline \multirow[t]{2}{*}{$\mathrm{NC} 2$} & 290727098211301 & ZL-68-62-108 & $6 / 17 / 2004$ & 1100 & 22 & E5.5 & E6.8 & E304 & E27.5 & 22.1 & 4.72 & 6.37 & 20.7 & 48 & E59 & $\mathrm{E}<1$ \\
\hline & & & $7 / 15 / 2008$ & 1800 & 12 & 1.7 & 6.3 & E270 & 28.0 & 18.1 & 4.04 & 6.54 & 19.6 & 45 & 54 & $<1$ \\
\hline \multirow[t]{3}{*}{ NC3 } & 290849098174001 & ZL-68-54-807 & $6 / 14 / 2004$ & 1130 & 5.3 & $<1.0$ & 6.1 & 346 & 29.0 & 28.3 & 4.77 & 7.37 & 22.9 & 55 & E67 & $\mathrm{E}<1$ \\
\hline & & & $9 / 19 / 2005$ & 1310 & 13 & 3.9 & 6.6 & 349 & 29.0 & 28.9 & 4.97 & 7.35 & 22.0 & 58 & 70 & $<1$ \\
\hline & & & $7 / 21 / 2008$ & 0900 & 9.6 & $\mathrm{E} 4.2$ & E7.7 & E312 & E27.0 & 27.2 & 4.95 & 7.62 & 22.5 & 63 & 76 & $<1$ \\
\hline \multirow[t]{3}{*}{$\mathrm{NC} 4$} & 291330098143301 & ZL-68-55-111 & $6 / 15 / 2004$ & 0930 & 21 & $<1.0$ & 6.4 & 255 & 24.0 & 22.8 & 3.45 & 5.18 & 17.2 & 63 & E77 & $\mathrm{E}<1$ \\
\hline & & & $9 / 20 / 2005$ & 1030 & 16 & 2.9 & 6.5 & 253 & 24.5 & 22.7 & 3.46 & 5.1 & 15.5 & 64 & 78 & $<1$ \\
\hline & & & $7 / 14 / 2008$ & 1100 & 13 & 4.1 & 6.7 & E247 & 24.5 & 21.7 & 3.43 & 5.41 & 15.8 & 63 & 77 & $<1$ \\
\hline NC5 & 291728098052401 & ZL-68-48-708 & $6 / 16 / 2004$ & 1020 & $<2.0$ & 1.0 & 5.9 & 142 & 23.5 & 6.2 & 1.72 & 6.55 & 12.2 & 20 & E24 & $\mathrm{E}<1$ \\
\hline \multicolumn{17}{|c|}{ Western Carrizo wells } \\
\hline \multirow[t]{3}{*}{ WC1 } & 290403098293201 & AL-68-61-413 & $6 / 14 / 2004$ & 1330 & 2.5 & 5.9 & 7.2 & 561 & 29.0 & 54.1 & 11.20 & 6.92 & 36.4 & 167 & E204 & $\mathrm{E}<1$ \\
\hline & & & $9 / 19 / 2005$ & 1010 & 5.7 & 4.5 & 7.2 & 531 & 29.5 & 58.8 & 11.70 & 7.16 & 34.0 & 162 & 198 & $<1$ \\
\hline & & & $8 / 14 / 2008$ & 1200 & E1.9 & 4.1 & 7.8 & 549 & 29.5 & 32.4 & 7.07 & 6.14 & 72.1 & $\mathrm{E} 82$ & 100 & $<1$ \\
\hline WC2 & 290001098250101 & AL-68-61-810 & $6 / 18 / 2004$ & 0950 & 3.4 & 5.2 & 7.6 & 503 & 33.0 & 60.7 & 6.61 & 5.68 & 27.3 & 158 & E193 & $\mathrm{E}<1$ \\
\hline & & & $9 / 19 / 2005$ & 1030 & 2.6 & 5.9 & 7.6 & 507 & 33.5 & 61.4 & 7.01 & 6.21 & 28.6 & 167 & 204 & $<1$ \\
\hline & & & 9/19/2005 dup & 1035 & 2.8 & 5.9 & 7.6 & 507 & 33.5 & 61.4 & 7.00 & 6.14 & 28.6 & 165 & 201 & $<1$ \\
\hline WC3 & 285738098301401 & AL-78-04-312 & $6 / 15 / 2004$ & 1330 & 4.4 & $<1.0$ & 7.0 & 589 & 34.0 & 77.3 & 7.40 & 5.61 & 29.2 & 188 & E229 & $\mathrm{E}<1$ \\
\hline & & & $9 / 21 / 2005$ & 1000 & 3.1 & 4.8 & 7.0 & 588 & 34.0 & 76.6 & 7.37 & 5.53 & 26.4 & 191 & 233 & $<1$ \\
\hline & & & $7 / 11 / 2008$ & 1000 & E1.7 & 5.2 & 7.5 & 565 & 33.0 & 74.2 & 7.60 & 5.74 & 27.1 & 184 & 224 & $<1$ \\
\hline WC4 & 285548098310901 & AL-78-04-612 & $6 / 18 / 2004$ & 1230 & 10 & $<1.0$ & 7.1 & 584 & 34.5 & 82.5 & 8.77 & 6.35 & 23.1 & 206 & E251 & $E<1$ \\
\hline & & & $9 / 21 / 2005$ & 1050 & $<2.0$ & 4.7 & 7.1 & 584 & 35.5 & 84.2 & 9.00 & 6.46 & 23.6 & 223 & 272 & $<1$ \\
\hline & & & $7 / 10 / 2008$ & 0900 & 2.4 & 5.5 & 7.5 & 589 & 35.5 & 79.4 & 9.09 & 6.51 & 23.5 & 220 & 267 & $<1$ \\
\hline & & & & & & astern C & arrizo w & ells & & & & & & & & \\
\hline $\mathrm{EC} 1$ & 290748098085601 & ZL-68-55-907 & $6 / 15 / 2004$ & 1030 & 3.9 & $<1.0$ & 7.2 & 668 & 35.5 & 39.3 & 13.00 & 10.4 & 82.8 & 243 & E296 & $\mathrm{E}<1$ \\
\hline & & & $9 / 20 / 2005$ & 1140 & $<2.0$ & 3.0 & 7.4 & 651 & 35.5 & 39.2 & 12.80 & 10.4 & 78.0 & 242 & 294 & $<1$ \\
\hline & & & $8 / 13 / 2008$ & 1400 & $<2.0$ & E4.0 & E7.6 & E662 & E35.5 & 36.1 & 12.20 & 10.7 & 82.2 & E155 & E188 & $E<1$ \\
\hline & & & 8/13/2008 dup & 1405 & $<2.0$ & $\mathrm{E} 4.0$ & E7.6 & E662 & E35.5 & 36.0 & 12.20 & 10.6 & 82.7 & E139 & E169 & $\mathrm{E}<1$ \\
\hline $\mathrm{EC} 2$ & 290037098113701 & ZL-68-63-803 & $6 / 14 / 2004$ & 0950 & $<2.0$ & $<1.0$ & 7.5 & 682 & 42.5 & 17.4 & 6.34 & 7.74 & 138 & 279 & E340 & $\mathrm{E}<1$ \\
\hline & & & $9 / 20 / 2005$ & 1318 & 5.9 & 2.2 & 7.7 & 697 & 42.5 & 12.8 & 5.05 & 6.94 & 135 & 312 & 378 & 1 \\
\hline & & & $8 / 27 / 2008$ & 1100 & 4.7 & 3.4 & 7.6 & 652 & 45.0 & 51.2 & 14.20 & 11.0 & 55.7 & 223 & 271 & $<1$ \\
\hline EC3 & 291122098062301 & ZL-68-56-408 & $6 / 18 / 2004$ & 1030 & $<2.0$ & $<1.0$ & 7.7 & 816 & 30.5 & 8.1 & 3.40 & 5.88 & 172 & 327 & E399 & $\mathrm{E}<1$ \\
\hline & & & & & & Carrizo-V & Vilcox w & & & & & & & & & \\
\hline WX1 & 291547098153501 & ZL-68-46-902 & $6 / 17 / 2004$ & 1000 & 9.8 & $<1.0$ & 7.3 & 1,710 & 26.0 & 57.7 & 18.40 & 5.51 & 304 & 267 & E326 & $\mathrm{E}<1$ \\
\hline & & & 6/17/2004 dup & 1010 & 10 & -- & 7.3 & 1,710 & 26.0 & 57.0 & 18.60 & 5.45 & 308 & 267 & E326 & $\mathrm{E}<1$ \\
\hline & & & 9/20/2005 & 1108 & 9.8 & 4.4 & 7.5 & 1,720 & 26.5 & 57.2 & 18.90 & 5.39 & 288 & 262 & 318 & $<1$ \\
\hline & & & $7 / 14 / 2008$ & 0900 & 19 & 3.4 & 7.6 & 1,720 & 25.0 & 55.6 & 17.70 & 5.59 & 288 & 264 & 319 & 1 \\
\hline
\end{tabular}


Appendix 1. Chemical and isotope data from wells sampled at and near an aquifer storage and recovery site, Bexar, Atascosa, and Wilson Counties, Texas, 2004-08-Continued.

\begin{tabular}{|c|c|c|c|c|c|c|c|c|c|c|c|c|c|c|c|c|}
\hline $\begin{array}{c}\text { Well } \\
\text { name } \\
\text { (fig. 1) }\end{array}$ & Date & $\begin{array}{l}\text { Hydrox- } \\
\text { ide } \\
\text { (mg/L) }\end{array}$ & $\begin{array}{l}\text { Chlo- } \\
\text { ride } \\
\text { (mg/L) }\end{array}$ & $\begin{array}{l}\text { Fluo- } \\
\text { ride } \\
\text { (mg/L) }\end{array}$ & $\begin{array}{l}\text { Silica } \\
\text { (mg/L) }\end{array}$ & $\begin{array}{c}\text { Sulfate } \\
\text { (mg/L) }\end{array}$ & $\begin{array}{c}\text { Residue } \\
\text { (sum of } \\
\text { con- } \\
\text { stituents) } \\
\text { (mg/L) }\end{array}$ & $\begin{array}{c}\text { Dissolved } \\
\text { ammonia } \\
\text { plus } \\
\text { organic } \\
\text { nitrogen } \\
\text { (mg/L) }\end{array}$ & $\begin{array}{c}\text { Dis- } \\
\text { solved } \\
\text { ammonia } \\
\text { nitrogen } \\
\text { (mg/L) }\end{array}$ & $\begin{array}{c}\text { Dissolved } \\
\text { nitrate } \\
\text { plus } \\
\text { nitrite } \\
\text { nitrogen } \\
\text { (mg/L) }\end{array}$ & $\begin{array}{c}\text { Dis- } \\
\text { solved } \\
\text { nitrite } \\
\text { nitrogen } \\
\text { (mg/L) }\end{array}$ & $\begin{array}{c}\text { Dissolved } \\
\text { orthophos- } \\
\text { phate } \\
\text { phos- } \\
\text { phorus } \\
\text { (mg/L) }\end{array}$ & $\begin{array}{l}\text { Dis- } \\
\text { solved } \\
\text { phos- } \\
\text { phorus } \\
\text { (mg/L) }\end{array}$ & $\begin{array}{c}\text { Alumi- } \\
\text { num } \\
(\mu \mathrm{g} / \mathrm{L})\end{array}$ & $\begin{array}{l}\text { Anti- } \\
\text { mony } \\
(\mu \mathrm{g} / \mathrm{L})\end{array}$ & $\begin{array}{c}\text { Arsenic } \\
(\mu \mathrm{g} / \mathrm{L})\end{array}$ \\
\hline \multicolumn{17}{|c|}{ Edwards aquifer source wells } \\
\hline ED1 & $5 / 9 / 2005$ & $<1$ & 23.6 & 0.28 & 13.2 & 24.8 & 289 & -- & -- & -- & -- & -- & -- & 4.3 & $<0.20$ & 0.60 \\
\hline ED2 & $5 / 9 / 2005$ & $<1$ & 23.1 & .29 & 13.2 & 23.9 & 295 & -- & -- & -- & -- & -- & -- & 2.8 & $<.20$ & .50 \\
\hline \multicolumn{17}{|c|}{ Carrizo aquifer monitoring wells } \\
\hline MW1 & $5 / 31 / 2005$ & $<1$ & 25.4 & .28 & 11.5 & 26.7 & 221 & -- & -- & -- & -- & -- & -- & 6.0 & $<.20$ & .30 \\
\hline MW2 & $5 / 12 / 2005$ & $<1$ & 28.1 & .18 & 17.8 & 20.7 & 193 & -- & -- & -- & -- & -- & -- & E.9 & $<.20$ & .60 \\
\hline \multicolumn{17}{|c|}{ ASR recovery wells } \\
\hline RW1 & $7 / 18 / 2008$ & $<1$ & 19.2 & .35 & 11.8 & 39.3 & 264 & -- & -- & -- & -- & -- & -- & 1.8 & $<.14$ & .79 \\
\hline RW2 & $7 / 18 / 2008$ & $<1$ & 18.6 & .47 & 11.3 & 38.9 & 299 & -- & -- & -- & -- & -- & -- & E1.5 & $<.14$ & .90 \\
\hline ASR-PO2 & $7 / 28 / 2008$ & $<1$ & 35.0 & $<.12$ & 24.4 & 18.0 & 147 & -- & -- & -- & -- & -- & -- & $<1.6$ & $<.14$ & .14 \\
\hline ASR-PO3 & $7 / 28 / 2008$ & $<1$ & 34.8 & E.06 & 24.9 & 19.3 & 142 & -- & -- & -- & -- & -- & -- & $<1.6$ & $<.14$ & .28 \\
\hline \multicolumn{17}{|c|}{ Northern Carrizo wells } \\
\hline \multirow[t]{3}{*}{$\mathrm{NC} 1$} & $6 / 16 / 2004$ & $\mathrm{E}<1$ & 54.6 & $<.17$ & 16.4 & 34.3 & 238 & $<0.10$ & E0.03 & $<0.06$ & $<0.008$ & $<0.02$ & $<0.04$ & $<1.6$ & $<.20$ & E. 2 \\
\hline & $9 / 21 / 2005$ & $<1$ & 57.3 & .11 & 17.2 & 41.1 & 225 & -- & -- & -- & -- & -- & -- & $<1.6$ & $<.20$ & .17 \\
\hline & $8 / 27 / 2008$ & $<1$ & 65.2 & E.11 & 15.5 & 55.3 & 284 & -- & -- & -- & -- & -- & -- & $<1.6$ & $<.14$ & .24 \\
\hline \multirow[t]{2}{*}{$\mathrm{NC} 2$} & $6 / 17 / 2004$ & $\mathrm{E}<1$ & 37.8 & $<.17$ & 18.5 & 22.7 & 165 & $<.10$ & $<.04$ & $<.06$ & $<.008$ & $<.02$ & $<.04$ & $<1.6$ & $<.20$ & E. 2 \\
\hline & $7 / 15 / 2008$ & $<1$ & 34.6 & .12 & 18.2 & 22.7 & 165 & -- & -- & -- & -- & -- & -- & $<1.6$ & $<.14$ & .11 \\
\hline \multirow[t]{3}{*}{ NC3 } & $6 / 14 / 2004$ & $\mathrm{E}<1$ & 44.7 & $<.17$ & 16.6 & 33.1 & 207 & E.08 & E.03 & $<.06$ & $<.008$ & $<.02$ & $<.04$ & $<1.6$ & $<.20$ & E.1 \\
\hline & $9 / 19 / 2005$ & $<1$ & 45.2 & .14 & 15.1 & 28.9 & 197 & -- & -- & -- & -- & -- & -- & $<1.6$ & $<.20$ & .18 \\
\hline & $7 / 21 / 2008$ & $<1$ & 44.2 & .13 & 15.2 & 28.0 & 204 & -- & -- & -- & -- & -- & -- & $<1.6$ & $<.14$ & .27 \\
\hline NC4 & $6 / 15 / 2004$ & $\mathrm{E}<1$ & 26.0 & .17 & 24.4 & 14.3 & 156 & .24 & .25 & $<.06$ & $<.008$ & $<.02$ & $<.04$ & $<1.6$ & $<.20$ & $<.2$ \\
\hline & 9/19/2005 & $<1$ & 34.6 & .39 & 15.1 & 35.1 & 296 & -- & -- & -- & -- & -- & -- & $<1.6$ & $<.20$ & $<.12$ \\
\hline & 9/19/2005 dup & $<1$ & 34.5 & .39 & 15.1 & 35.0 & 284 & -- & -- & -- & -- & -- & -- & 2.4 & $<.20$ & $<.12$ \\
\hline WC3 & $6 / 15 / 2004$ & $\mathrm{E}<1$ & 37.3 & .31 & 15.4 & 43.5 & 296 & $<.10$ & E.03 & $<.06$ & $<.008$ & $<.02$ & $<.04$ & $<1.6$ & $<.20$ & $<.2$ \\
\hline & $9 / 21 / 2005$ & $<1$ & 36.5 & .33 & 14.9 & 44.8 & 346 & -- & -- & -- & -- & -- & -- & $<1.6$ & $<.20$ & $<.12$ \\
\hline & $7 / 11 / 2008$ & $<1$ & 34.4 & .32 & 14 & 42.7 & 343 & -- & -- & -- & -- & -- & -- & $<1.6$ & $<.14$ & $<.06$ \\
\hline WC4 & $6 / 18 / 2004$ & $E<1$ & 31.9 & .4 & 15.3 & 27.9 & 276 & E.07 & E. 03 & $<.06$ & $<.008$ & $<.02$ & $<.04$ & $<1.6$ & $<.20$ & $<.2$ \\
\hline & $9 / 21 / 2005$ & $<1$ & 30.1 & .42 & 15.8 & 30.7 & 340 & -- & -- & -- & -- & -- & -- & $<1.6$ & $<.20$ & $<.12$ \\
\hline & $7 / 10 / 2008$ & $<1$ & 29.0 & .39 & 14.5 & 30.2 & 344 & -- & -- & -- & -- & -- & -- & E1.0 & $<.14$ & $<.06$ \\
\hline & & & & & & & Easter & n Carrizo w & & & & & & & & \\
\hline EC1 & $6 / 15 / 2004$ & $\mathrm{E}<1$ & 32.8 & .42 & 18.9 & 46.6 & 368 & $<.10$ & E.04 & $<.06$ & $<.008$ & E.01 & .21 & E. 8 & $<.20$ & $<.2$ \\
\hline & 9/20/2005 & $<1$ & 30.9 & .42 & 18.6 & 44.6 & 387 & -- & -- & -- & -- & -- & -- & $<1.6$ & $<.20$ & $<.12$ \\
\hline & $8 / 13 / 2008$ & $<1$ & 29.9 & .41 & 17.4 & 45.5 & 394 & -- & -- & -- & -- & -- & -- & $<1.6$ & $<.14$ & $<.06$ \\
\hline & 8/13/2008 dup & $<1$ & 30.0 & .41 & 17.1 & 45.5 & 392 & -- & -- & -- & -- & -- & -- & $<1.6$ & $<.14$ & $<.06$ \\
\hline EC2 & $6 / 14 / 2004$ & $\mathrm{E}<1$ & 36.9 & .45 & 19.3 & 38.2 & 427 & .32 & .32 & $<.06$ & $<.008$ & E. 01 & $<.04$ & 7.5 & $<.20$ & $<.2$ \\
\hline & $9 / 20 / 2005$ & $<1$ & 32.7 & .47 & 19.4 & 1.31 & 426 & -- & -- & -- & -- & -- & -- & 2.2 & $<.20$ & $<.12$ \\
\hline & $8 / 27 / 2008$ & $<1$ & 29.9 & .42 & 18.2 & 47.8 & 370 & -- & -- & -- & -- & -- & -- & $<1.6$ & $<.14$ & $<.06$ \\
\hline EC3 & $6 / 18 / 2004$ & $\mathrm{E}<1$ & 35.3 & .52 & 16.2 & 44.9 & 478 & .55 & .45 & $<.06$ & $<.008$ & $<.02$ & $<.04$ & E.9 & $<.20$ & $<.2$ \\
\hline & & & & & & & Carriz & o-Wilcox W & & & & & & & & \\
\hline WX1 & 6/17/2004 & $\mathrm{E}<1$ & 170 & .73 & 22.2 & 328 & 1,040 & .51 & .47 & $<.06$ & $<.008$ & $<.02$ & $<.04$ & $<1.6$ & $<.20$ & E. 2 \\
\hline & 6/17/2004 dup & $\mathrm{E}<1$ & 170 & .73 & 21.8 & 326 & 1,080 & .51 & .48 & $<.06$ & $<.008$ & $<.02$ & $<.04$ & $<1.6$ & $<.20$ & E. 2 \\
\hline & 9/20/2005 & $<1$ & 170 & .74 & 23.4 & 344 & 1,100 & -- & -- & -- & -- & -- & -- & $<1.6$ & $<.20$ & $<.12$ \\
\hline & $7 / 14 / 2008$ & $<1$ & 163 & .73 & 18.1 & 347 & 1,070 & -- & -- & -- & -- & -- & -- & $<1.6$ & $<.14$ & E.05 \\
\hline
\end{tabular}


Appendix 1. Chemical and isotope data from wells sampled at and near an aquifer storage and recovery site, Bexar, Atascosa, and Wilson Counties, Texas, 2004-08-Continued.

\begin{tabular}{|c|c|c|c|c|c|c|c|c|c|c|c|c|c|c|c|c|c|}
\hline $\begin{array}{c}\text { Well name } \\
\text { (fig. 1) }\end{array}$ & Date & $\begin{array}{c}\text { Barium } \\
\text { ( } \mu \mathrm{g} / \mathrm{L})\end{array}$ & $\begin{array}{c}\text { Beryl- } \\
\text { lium } \\
(\mu \mathrm{g} / \mathrm{L})\end{array}$ & $\begin{array}{l}\text { Boron } \\
\text { ( } \mu \mathrm{g} / \mathrm{L})\end{array}$ & $\begin{array}{l}\text { Cad- } \\
\text { mium } \\
(\mu \mathrm{g} / \mathrm{L})\end{array}$ & $\begin{array}{l}\text { Chro- } \\
\text { mium } \\
(\mu \mathrm{g} / \mathrm{L})\end{array}$ & $\begin{array}{c}\text { Cobalt } \\
\text { ( } \mu \mathrm{g} / \mathrm{L})\end{array}$ & $\begin{array}{c}\text { Copper } \\
\text { ( } \mu \mathrm{g} / \mathrm{L})\end{array}$ & $\begin{array}{c}\text { Dis- } \\
\text { solved } \\
\text { iron } \\
(\mu \mathrm{g} / \mathrm{L})\end{array}$ & $\begin{array}{l}\text { Total } \\
\text { iron } \\
(\mu \mathrm{g} / \mathrm{L})\end{array}$ & $\begin{array}{c}\text { Lead } \\
\text { ( } \mu \mathrm{g} / \mathrm{L})\end{array}$ & $\begin{array}{c}\text { Lithium } \\
\text { ( } \mu \mathrm{g} / \mathrm{L})\end{array}$ & $\begin{array}{c}\text { Dissolved } \\
\text { manga- } \\
\text { nese } \\
(\mu \mathrm{g} / \mathrm{L})\end{array}$ & $\begin{array}{c}\text { Total } \\
\text { manga- } \\
\text { nese } \\
(\mu \mathrm{g} / \mathrm{L})\end{array}$ & $\begin{array}{c}\text { Molyb- } \\
\text { denum } \\
(\mu \mathrm{g} / \mathrm{L})\end{array}$ & $\begin{array}{c}\text { Nickel } \\
(\mu \mathrm{g} / \mathrm{L})\end{array}$ & $\begin{array}{l}\text { Sele- } \\
\text { nium } \\
(\mu \mathrm{g} / \mathrm{L})\end{array}$ \\
\hline \multicolumn{18}{|c|}{ Edwards aquifer source wells } \\
\hline ED1 & $5 / 9 / 2005$ & 115 & $<0.06$ & 63 & $<0.04$ & $<.8$ & 0.13 & 1.6 & $<6$ & $<6$ & 0.09 & 10.2 & $<0.2$ & $<0.2$ & 3.1 & 0.90 & 0.90 \\
\hline ED2 & $5 / 9 / 2005$ & 114 & $<.06$ & 61 & $<.04$ & $<.8$ & .12 & 1.0 & $<6$ & E3 & .18 & 9.7 & .3 & .2 & 2.4 & .91 & 1.0 \\
\hline \multicolumn{18}{|c|}{ ASR injection well } \\
\hline IW1 & $5 / 9 / 2005$ & 107 & E.05 & 63 & $<.04$ & $<.8$ & .12 & .9 & $<6$ & $<6$ & .11 & 10.0 & $<.2$ & $<.2$ & 3.1 & .77 & 1.0 \\
\hline \multicolumn{18}{|c|}{ Carrizo aquifer monitoring wells } \\
\hline MW1 & $5 / 31 / 2005$ & 136 & $<.06$ & 105 & $<.04$ & $<.8$ & .07 & E.3 & 95 & 7,010 & $<.08$ & 36.3 & 15.1 & 131 & 2.2 & 1.18 & $<.4$ \\
\hline MW2 & $5 / 12 / 2005$ & 139 & E.04 & 58 & $<.04$ & $<.8$ & .12 & E.3 & 6,020 & 5,710 & $<.08$ & 13.5 & 124 & 106 & 5.1 & 1.10 & E. 3 \\
\hline \multicolumn{18}{|c|}{ ASR recovery wells } \\
\hline RW1 & $7 / 18 / 2008$ & 70 & $<.01$ & 49 & $<.04$ & $<.12$ & .55 & 3.5 & E5 & 6 & 2.63 & 3.9 & 11.6 & 13.4 & 1.8 & .63 & E.02 \\
\hline RW2 & $7 / 18 / 2008$ & 57 & $<.01$ & 46 & E.02 & $<.12$ & 1.60 & 1.1 & 11 & 14 & 3.60 & 4.1 & 5.8 & 6.3 & 6.0 & 1.20 & $<.04$ \\
\hline RW3 & $7 / 18 / 2008$ & 62 & E.01 & 46 & E.03 & $<.12$ & 2.40 & 1.3 & 87 & 105 & 1.45 & 4.3 & 8.6 & 9.4 & 4.1 & 1.70 & $<.04$ \\
\hline RW4 & $7 / 18 / 2008$ & 78 & .01 & 48 & E.03 & $<.12$ & 4.20 & 1.2 & 279 & 311 & 1.72 & 4.9 & 15.8 & 18.3 & 7.7 & 3.00 & $<.04$ \\
\hline \multicolumn{18}{|c|}{ ASR production-only wells } \\
\hline ASR-PO1 & $7 / 28 / 2008$ & 110 & .17 & 46 & $<.04$ & $<.12$ & 2.70 & $<1.0$ & 683 & 651 & .25 & 9.3 & 25.4 & 26.1 & .2 & 5.70 & $<.04$ \\
\hline ASR-PO2 & $7 / 28 / 2008$ & 90 & .10 & 44 & $<.04$ & $<.12$ & .92 & $<1.0$ & 373 & 368 & .16 & 7.7 & 10.8 & 11.8 & $<.2$ & 3.10 & $<.04$ \\
\hline ASR-PO3 & $7 / 28 / 2008$ & 84 & .10 & 37 & $<.04$ & $<.12$ & .81 & $<1.0$ & 455 & 438 & .24 & 7.3 & 9.2 & 10.0 & .6 & 3.30 & $<.04$ \\
\hline \multicolumn{18}{|c|}{ Northern Carrizo wells } \\
\hline \multirow[t]{3}{*}{$\mathrm{NC} 1$} & $6 / 16 / 2004$ & 130 & E.03 & 71 & $<.04$ & $<.8$ & .42 & E. 3 & 1,440 & 1,710 & $<.08$ & 16.2 & 77.4 & 83.9 & E. 3 & 1.23 & $<.4$ \\
\hline & $9 / 21 / 2005$ & 137 & E.04 & 53 & $<.04$ & $<.04$ & .31 & .61 & 1,440 & 1,360 & $<.08$ & 15.2 & 66.4 & 57.4 & E. 3 & .45 & $<.08$ \\
\hline & $8 / 27 / 2008$ & 153 & .07 & 65 & $<.04$ & $<.12$ & .34 & 1.6 & 1,240 & 1,170 & $<.08$ & 15.1 & 64.6 & 71.3 & .4 & .85 & $<.04$ \\
\hline \multirow[t]{2}{*}{$\mathrm{NC} 2$} & $6 / 17 / 2004$ & 100 & .07 & 58 & $<.04$ & $<.8$ & .72 & E. 2 & 2,550 & 2,580 & $<.08$ & 9.7 & 46.6 & 48.5 & E. 3 & 1.24 & $<.4$ \\
\hline & $7 / 15 / 2008$ & 89 & .06 & 43 & $<.04$ & $<.12$ & .73 & $<1.0$ & 4,690 & 6,080 & $<.08$ & 8.0 & 76.1 & 88.8 & .3 & 2.00 & $<.04$ \\
\hline \multirow[t]{3}{*}{$\mathrm{NC} 3$} & $6 / 14 / 2004$ & 91 & $<.06$ & 62 & $<.04$ & $<.8$ & .07 & E. 3 & 1,400 & 1,430 & $<.08$ & 13.6 & 51.7 & 50.3 & E. 4 & .17 & E. 2 \\
\hline & $9 / 19 / 2005$ & 98 & $<.06$ & 50 & $<.04$ & $<.04$ & .07 & E.4 & 2,530 & 2,550 & $<.08$ & 12.4 & 136 & 127 & .7 & 1.01 & $<.08$ \\
\hline & $7 / 21 / 2008$ & 89 & .02 & 59 & $<.04$ & $<.12$ & $<.02$ & $<1.0$ & 3,270 & 2,250 & .17 & 12.8 & 162 & 247 & .8 & .25 & $<.04$ \\
\hline \multirow[t]{3}{*}{$\mathrm{NC} 4$} & $6 / 15 / 2004$ & 104 & $<.06$ & 51 & $<.04$ & $<.8$ & .05 & E.3 & 2,310 & 2,300 & $<.08$ & 13.6 & 125 & 124 & $<.4$ & .11 & $<.4$ \\
\hline & $9 / 20 / 2005$ & 99 & $<.06$ & 53 & $<.04$ & $<.04$ & $<.04$ & $<.40$ & 2,150 & 1,980 & E.04 & 16.3 & 136 & 141 & $<.4$ & $<.06$ & $<.08$ \\
\hline & $7 / 14 / 2008$ & 99 & .01 & 43 & $<.04$ & $<.12$ & $<.02$ & $<1.0$ & 1,920 & 1,980 & $<.08$ & 12.8 & 118 & 132 & E. 1 & $<.20$ & $<.04$ \\
\hline NC5 & $6 / 16 / 2004$ & 77 & .10 & 34 & $<.04$ & $<.8$ & .79 & E.4 & 1,130 & 1,130 & .13 & 11.0 & 31.8 & 33.2 & $<.4$ & 3.35 & $<.4$ \\
\hline \multicolumn{18}{|c|}{ Western Carrizo wells } \\
\hline WC1 & $6 / 14 / 2004$ & 75 & $<.06$ & 96 & $<.04$ & $<.8$ & .13 & .40 & 10 & 622 & $<.08$ & 34.1 & 26.7 & 25.8 & $<.4$ & .39 & E. 3 \\
\hline & $9 / 19 / 2005$ & 73 & $<.06$ & 93 & $<.04$ & $<.04$ & $<.04$ & $<.40$ & 597 & 575 & $<.08$ & 37.6 & 24.0 & 26.7 & E. 2 & $<.06$ & $<.08$ \\
\hline & $8 / 14 / 2008$ & 66 & M & 148 & $<.04$ & $<.12$ & E.02 & $<1.0$ & $<8$ & 397 & $<.08$ & 34.0 & 34.3 & 38.2 & .4 & E. 15 & $<.04$ \\
\hline WC2 & $6 / 18 / 2004$ & 127 & $<.06$ & 145 & $<.04$ & $<.8$ & .14 & .50 & $<6$ & 739 & $<.08$ & 16.1 & 77.0 & 81.6 & 1.2 & .29 & $<.4$ \\
\hline & $9 / 19 / 2005$ & 116 & $<.06$ & 134 & $<.04$ & $<.04$ & $<.04$ & .67 & 32 & 688 & $<.08$ & 16.9 & 68.3 & 74.8 & 1.2 & $<.06$ & $<.08$ \\
\hline & 9/19/2005 dup & 117 & $<.06$ & 133 & $<.04$ & $<.04$ & .14 & .40 & 11 & 681 & $<.08$ & 17.1 & 78.8 & 77.1 & 1.2 & 2.10 & $<.08$ \\
\hline WC3 & $6 / 15 / 2004$ & 129 & $<.06$ & 120 & $<.04$ & $<.8$ & .18 & .40 & 124 & 608 & $<.08$ & 15.7 & 132 & 131 & .8 & .43 & $<.4$ \\
\hline & $9 / 21 / 2005$ & 123 & $<.06$ & 97 & $<.04$ & $<.04$ & $<.04$ & .67 & 55 & 619 & $<.08$ & 14.7 & 161 & 134 & .9 & E.04 & $<.08$ \\
\hline & $7 / 11 / 2008$ & 127 & .01 & 122 & $<.04$ & $<.12$ & .03 & $<1.0$ & 146 & 361 & $<.08$ & 14.7 & 134 & 138 & .8 & .28 & $<.04$ \\
\hline WC4 & $6 / 18 / 2004$ & 190 & $<.06$ & 144 & $<.04$ & $<.8$ & .19 & E. 4 & 10 & 1,130 & $<.08$ & 16.5 & 59.3 & 62.8 & 1.0 & .45 & E. 2 \\
\hline & $9 / 21 / 2005$ & 175 & $<.06$ & 134 & $<.04$ & $<.04$ & $<.04$ & .62 & 20 & 386 & $<.08$ & 15.2 & 45.6 & 49.3 & 1.1 & $<.06$ & $<.08$ \\
\hline & $7 / 10 / 2008$ & 184 & .01 & 146 & $<.04$ & $<.12$ & $<.02$ & $<1.0$ & 118 & 518 & $<.08$ & 15.5 & 52.2 & 55.7 & 1.0 & E. 12 & $<.04$ \\
\hline & & & & & & & & tern Carri & o wells & & & & & & & & \\
\hline $\mathrm{EC} 1$ & $6 / 15 / 2004$ & 109 & $<.06$ & 142 & $<.04$ & $<.8$ & .09 & .40 & 363 & 227 & $<.08$ & 38.2 & 19.7 & 18.9 & $<.4$ & .27 & $<.4$ \\
\hline & $9 / 20 / 2005$ & 110 & $<.06$ & 157 & $<.04$ & $<.04$ & $<.04$ & $<.40$ & 161 & 155 & $<.08$ & 41.9 & 14.5 & 16.4 & $<.4$ & $<.06$ & $<.08$ \\
\hline & $8 / 13 / 2008$ & 119 & .01 & 130 & $<.04$ & $<.12$ & E.02 & $<1.0$ & 41 & 48 & .31 & 36.6 & 12.7 & 14.2 & $<.2$ & .28 & $<.04$ \\
\hline & $8 / 13 / 2008$ dup & 119 & .01 & 128 & $<.04$ & $<.12$ & .04 & $<1.0$ & 41 & 53 & $<.08$ & 36.7 & 12.4 & 14.1 & $<.2$ & .23 & $<.04$ \\
\hline $\mathrm{EC} 2$ & $6 / 14 / 2004$ & 163 & $<.06$ & 192 & $<.04$ & $<.8$ & .04 & .50 & 16 & 23 & $<.08$ & 44.4 & 17.0 & 16.4 & $<.4$ & .50 & .90 \\
\hline & $9 / 20 / 2005$ & 156 & $<.06$ & 220 & $<.04$ & .05 & $<.04$ & $<.40$ & 136 & 292 & $<.08$ & 47.4 & 18.3 & 20.7 & $<.4$ & $<.06$ & .11 \\
\hline & $8 / 27 / 2008$ & 144 & E.01 & 111 & $<.04$ & $<.12$ & .02 & $<1.0$ & 30 & 643 & $<.08$ & 30.6 & 22.4 & 24.4 & $<.2$ & .35 & $<.04$ \\
\hline EC3 & $6 / 18 / 2004$ & 171 & $<.06$ & 230 & $<.04$ & $<.8$ & .02 & .60 & 29 & 42 & $<.08$ & 47.6 & 8.2 & 9.0 & $<.4$ & E. 04 & E. 2 \\
\hline & & & & & & & & rrizo-Wilc & x well & & & & & & & & \\
\hline WX1 & $6 / 17 / 2004$ & 17 & $<.06$ & 405 & $<.04$ & $<.8$ & .15 & 1.6 & 109 & 1,190 & $<.08$ & 124 & 24.7 & 29.3 & 1.7 & .37 & .60 \\
\hline & 6/17/2004 dup & 17 & $<.06$ & 410 & $<.04$ & $<.8$ & .15 & 1.6 & 120 & 1,130 & $<.08$ & 124 & 24.7 & 28.6 & 1.7 & .36 & .70 \\
\hline & $9 / 20 / 2005$ & 17 & $<.06$ & 447 & $<.04$ & $<.04$ & $<.04$ & $<.40$ & 1,300 & 1,360 & $<.08$ & 153 & 24.0 & 28.9 & 1.9 & $<.06$ & $<.08$ \\
\hline & $7 / 14 / 2008$ & 18 & $<.01$ & 451 & $<.04$ & $<.12$ & .04 & $<1.0$ & 28 & 1,760 & $<.08$ & 127 & 34.2 & 41.8 & 1.8 & .45 & E.03 \\
\hline
\end{tabular}


Appendix 1. Chemical and isotope data from wells sampled at and near an aquifer storage and recovery site, Bexar, Atascosa, and Wilson Counties, Texas, 2004-08-Continued.

\begin{tabular}{|c|c|c|c|c|c|c|c|c|c|c|c|c|c|c|c|c|c|}
\hline $\begin{array}{c}\text { Well name } \\
\text { (fig. 1) }\end{array}$ & Date & $\begin{array}{l}\text { Silver } \\
\text { ( } \mu \mathrm{g} / \mathrm{L})\end{array}$ & $\begin{array}{c}\text { Strontium } \\
(\mu \mathrm{g} / \mathrm{L})\end{array}$ & $\begin{array}{l}\text { Vanadium } \\
(\mu \mathrm{g} / \mathrm{L})\end{array}$ & $\begin{array}{c}\text { Zinc } \\
(\mu \mathrm{g} / \mathrm{L})\end{array}$ & $\begin{array}{c}\text { Uranium } \\
(\mu \mathrm{g} / \mathrm{L})\end{array}$ & $\begin{array}{c}{ }^{226} \mathrm{Ra} \\
\text { (pCi/L) }\end{array}$ & $\begin{array}{c}{ }^{226} \mathrm{Ra} \\
\mathrm{PE} \\
\text { (pCi/L) }\end{array}$ & $\begin{array}{c}{ }^{226} \mathrm{Ra} \\
\mathrm{ssL} \\
(\mathrm{pCi} / \mathrm{L})\end{array}$ & $\begin{array}{l}{ }^{228} \mathrm{Ra} \\
\text { (pCi/L) }\end{array}$ & $\begin{array}{c}{ }^{228} \mathrm{Ra} \\
\mathrm{PE} \\
\text { (pCi/L) }\end{array}$ & $\begin{array}{c}{ }^{228} \mathrm{Ra} \\
\mathrm{ssL} \\
\text { (pCi/L) }\end{array}$ & ${ }^{87 / 86} \mathrm{Sr}$ & ${ }^{11 / 10} \mathrm{~B}$ & $\begin{array}{l}\delta^{11} \mathrm{~B} \\
\text { (per } \\
\text { mil) }\end{array}$ & $\begin{array}{c}\delta^{18} 0 \\
\text { (per mil) }\end{array}$ & $\begin{array}{c}\delta D \\
\text { (per } \\
\text { mil) }\end{array}$ \\
\hline \multicolumn{18}{|c|}{ Edwards aquifer source wells } \\
\hline ED1 & $5 / 9 / 2005$ & $<0.2$ & 1,660 & 4.7 & 1.3 & 0.87 & 0.644 & -- & 0.028 & 0.230 & -- & 0.450 & 0.70785 & 4.161 & 38.1 & -4.19 & -24.80 \\
\hline ED2 & $5 / 9 / 2005$ & $<.2$ & 1,570 & 4.8 & 6.5 & .83 & .639 & -- & .036 & R.17 & -- & .400 & .70790 & 4.157 & 39.1 & -4.18 & -24.70 \\
\hline \multicolumn{18}{|c|}{ ASR injection well } \\
\hline IW1 & $5 / 9 / 2005$ & $<.2$ & 1,600 & 4.6 & 9.5 & .84 & .624 & -- & .037 & .285 & -- & .420 & .70790 & 4.154 & 37.6 & -4.26 & -25.60 \\
\hline \multicolumn{18}{|c|}{ Carrizo aquifer monitoring wells } \\
\hline MW1 & $5 / 31 / 2005$ & $<.2$ & 455 & $<.1$ & E.6 & E.03 & .419 & -- & .035 & .987 & -- & .440 & .70862 & 4.119 & 28.6 & -5.10 & -28.60 \\
\hline MW2 & $5 / 12 / 2005$ & $<.2$ & 233 & E. 1 & .80 & $<.04$ & .672 & -- & .033 & 1.352 & -- & .410 & .70967 & 4.158 & 38.4 & -4.73 & -26.20 \\
\hline \multicolumn{18}{|c|}{ ASR recovery wells } \\
\hline RW1 & $7 / 18 / 2008$ & $<.1$ & 612 & 2.0 & 2.5 & .47 & .279 & 0.030 & .026 & R.08 & 0.130 & .620 & .70780 & 4.136 & 33.0 & -4.12 & -23.32 \\
\hline RW2 & $7 / 18 / 2008$ & $<.1$ & 613 & 1.7 & 5.7 & .67 & .277 & .032 & .030 & R.16 & .130 & .540 & .70781 & 4.151 & 36.7 & -4.09 & -22.73 \\
\hline RW3 & $7 / 18 / 2008$ & $<.1$ & 654 & 1.1 & 8.4 & .55 & .344 & .037 & .032 & R.01 & .160 & .750 & .70780 & 4.147 & 35.6 & -4.12 & -23.52 \\
\hline RW4 & $7 / 18 / 2008$ & $<.1$ & 572 & .81 & 29.3 & .27 & .340 & .026 & .033 & R.01 & .150 & .580 & .70802 & 4.150 & 36.5 & -4.22 & -24.58 \\
\hline \multicolumn{18}{|c|}{ ASR production-only wells } \\
\hline ASR-PO1 & $7 / 28 / 2008$ & $<.1$ & 95.1 & .10 & 30.3 & $<.02$ & .619 & .058 & .030 & 1.450 & .150 & .540 & .71345 & 4.180 & 43.8 & -4.94 & -28.07 \\
\hline ASR-PO2 & $7 / 28 / 2008$ & $<.1$ & 58.3 & .06 & 18.9 & $<.02$ & .527 & .051 & .030 & 1.080 & .140 & .600 & .71332 & 4.153 & 37.1 & -4.95 & -26.34 \\
\hline ASR-PO3 & $7 / 28 / 2008$ & $<.1$ & 58.8 & .07 & 82.1 & $<.02$ & .374 & .037 & .030 & 1.320 & .150 & .590 & .71332 & 4.153 & 37.1 & -4.98 & -27.19 \\
\hline \multicolumn{18}{|c|}{ Northern Carrizo wells } \\
\hline \multirow[t]{3}{*}{$\mathrm{NC} 1$} & $6 / 16 / 2004$ & $<.2$ & 195 & $<.1$ & 2.7 & $<.04$ & .276 & -- & .012 & 1.476 & -- & .540 & .71045 & 4.145 & 35.2 & -4.94 & -27.50 \\
\hline & $9 / 21 / 2005$ & $<.2$ & 169 & $<.10$ & 1.1 & $<.04$ & -- & -- & -- & -- & -- & -- & -- & -- & -- & -- & -- \\
\hline & $8 / 27 / 2008$ & $<.1$ & 205 & E.04 & 3.3 & $<.02$ & 1.100 & .100 & .037 & 2.070 & .160 & .480 & .71100 & 4.153 & 37.1 & -4.90 & -28.01 \\
\hline \multirow[t]{2}{*}{$\mathrm{NC} 2$} & $6 / 17 / 2004$ & $<.2$ & 108 & $<.1$ & 3.5 & $<.04$ & .222 & -- & .010 & 1.872 & -- & .700 & .71263 & 4.155 & 37.6 & -4.82 & -27.30 \\
\hline & $7 / 15 / 2008$ & $<.1$ & 92.8 & $<.04$ & $<1.8$ & $<.02$ & .564 & .054 & .029 & 1.130 & .150 & .560 & .71283 & 4.167 & 40.7 & -4.86 & -27.04 \\
\hline \multirow[t]{3}{*}{ NC3 } & $6 / 14 / 2004$ & $<.2$ & 154 & $<.1$ & 2.4 & $<.04$ & .416 & -- & .011 & 1.352 & -- & .530 & .71170 & 4.155 & 37.6 & -4.80 & -27.30 \\
\hline & $9 / 19 / 2005$ & $<.2$ & 161 & $<.10$ & 1.0 & $<.04$ & -- & -- & -- & -- & -- & -- & -- & -- & -- & -- & -- \\
\hline & $7 / 21 / 2008$ & $<.1$ & 145 & .05 & E1.5 & $<.02$ & .402 & .040 & .024 & .829 & .130 & .590 & .71199 & 4.172 & 41.8 & -4.90 & -27.28 \\
\hline \multirow[t]{3}{*}{$\mathrm{NC} 4$} & $6 / 15 / 2004$ & $<.2$ & 123 & $<.1$ & 2.0 & $<.04$ & .329 & -- & .009 & 1.180 & -- & .530 & .70952 & 4.145 & 35.1 & -4.90 & -26.60 \\
\hline & $9 / 20 / 2005$ & $<.2$ & 130 & $<.10$ & 3.3 & $<.04$ & -- & -- & -- & -- & -- & -- & -- & -- & -- & -- & -- \\
\hline & $7 / 14 / 2008$ & $<.1$ & 124 & $<.04$ & 4.5 & $<.02$ & .618 & .057 & .030 & 1.580 & .150 & .510 & .70947 & 4.149 & 36.2 & -4.97 & -27.67 \\
\hline NC5 & $6 / 16 / 2004$ & $<.2$ & 61.1 & $<.1$ & 9.5 & $<.04$ & .243 & -- & .011 & .553 & -- & .560 & .71107 & -- & -- & -4.85 & -25.70 \\
\hline \multicolumn{18}{|c|}{ Western Carrizo wells } \\
\hline WC1 & $6 / 14 / 2004$ & $<.2$ & 479 & .20 & 1.3 & $<.04$ & .343 & -- & .008 & 1.782 & -- & .530 & .70880 & 4.102 & 24.5 & -4.77 & -26.40 \\
\hline & $9 / 19 / 2005$ & $<.2$ & 461 & $<.10$ & 1.9 & $<.04$ & -- & -- & -- & -- & -- & -- & -- & -- & -- & -- & -- \\
\hline & $8 / 14 / 2008$ & $<.1$ & 378 & E.04 & $<1.8$ & $<.02$ & .501 & .049 & .034 & 1.740 & .180 & .500 & .70855 & 4.118 & 28.5 & -4.94 & -25.55 \\
\hline WC2 & $6 / 18 / 2004$ & $<.2$ & 308 & .50 & 1.2 & $<.04$ & .332 & -- & .015 & 1.946 & -- & .570 & .70898 & 4.140 & 32.8 & -4.38 & -24.00 \\
\hline & $9 / 19 / 2005$ & $<.2$ & 369 & $<.10$ & .74 & $<.04$ & -- & -- & -- & -- & -- & -- & -- & -- & -- & -- & -- \\
\hline & 9/19/2005 dup & $<.2$ & 372 & $<.10$ & .60 & $<.04$ & -- & -- & -- & -- & -- & -- & -- & -- & -- & -- & -- \\
\hline WC3 & $6 / 15 / 2004$ & $<.2$ & 302 & .20 & .70 & $<.04$ & 1.354 & -- & .008 & 2.700 & -- & .510 & .70923 & 4.138 & 33.6 & -4.32 & -24.70 \\
\hline & $9 / 21 / 2005$ & $<.2$ & 319 & $<.10$ & 1.4 & $<.04$ & -- & -- & -- & -- & -- & -- & -- & -- & -- & -- & -- \\
\hline & $7 / 11 / 2008$ & $<.1$ & 306 & $<.04$ & 5.6 & $<.02$ & 1.180 & .100 & .031 & 2.580 & .200 & .520 & .70915 & 4.144 & 35.0 & -4.40 & -24.35 \\
\hline WC4 & $6 / 18 / 2004$ & $<.2$ & 368 & .60 & 1.2 & $<.04$ & .740 & -- & .012 & 3.047 & -- & .530 & .70883 & 4.144 & 35.1 & -3.66 & -20.90 \\
\hline & $9 / 21 / 2005$ & $<.2$ & 404 & $<.10$ & $<.60$ & $<.04$ & -- & -- & -- & -- & -- & -- & -- & -- & -- & -- & -- \\
\hline & $7 / 10 / 2008$ & $<.1$ & 392 & $<.04$ & $<1.8$ & $<.02$ & 1.580 & .140 & .031 & 3.690 & .250 & .520 & .70877 & 4.138 & 33.3 & -3.74 & -20.59 \\
\hline & & & & & & & Eastern & Carrizo v & & & & & & & & & \\
\hline $\mathrm{EC} 1$ & $6 / 15 / 2004$ & -- & 925 & .30 & E. 6 & $<.04$ & .628 & -- & .011 & 1.731 & -- & .550 & .70824 & 4.117 & 28.1 & -4.58 & -26.40 \\
\hline & $9 / 20 / 2005$ & $<.2$ & 901 & $<.10$ & $<.60$ & $<.04$ & -- & -- & -- & -- & -- & -- & -- & -- & -- & -- & -- \\
\hline & $8 / 13 / 2008$ & $<.1$ & 941 & E.04 & $<1.8$ & $<.02$ & .557 & .053 & .031 & 1.920 & .240 & .600 & .70825 & 4.110 & 26.5 & -4.57 & -26.90 \\
\hline & 8/13/2008 dup & $<.1$ & 929 & E.04 & $<1.8$ & $<.02$ & .566 & .053 & .025 & 1.690 & .200 & .560 & .70823 & 4.126 & 30.5 & -4.65 & -25.68 \\
\hline $\mathrm{EC} 2$ & $6 / 14 / 2004$ & -- & 584 & .40 & E. 5 & $<.04$ & .254 & -- & .009 & 1.325 & -- & .540 & .70799 & 4.097 & 23.2 & -4.60 & -26.40 \\
\hline & $9 / 20 / 2005$ & $<.2$ & 488 & $<.10$ & 1.6 & $<.04$ & -- & -- & -- & -- & -- & -- & -- & -- & -- & -- & -- \\
\hline & $8 / 27 / 2008$ & $<.1$ & 917 & E.02 & E.98 & $<.02$ & .998 & .094 & .037 & 2.130 & .170 & .480 & .70843 & 4.138 & 33.3 & -4.58 & -27.64 \\
\hline EC3 & $6 / 18 / 2004$ & -- & 402 & 1.0 & .80 & $<.04$ & .164 & -- & .014 & .900 & -- & .550 & .70786 & 4.087 & 20.6 & -4.61 & -27.20 \\
\hline & & & & & & & Carrizo & -Wilcox & & & & & & & & & \\
\hline WX1 & $6 / 17 / 2004$ & $<.2$ & 1,660 & .10 & 2.4 & $<.04$ & .201 & -- & .009 & .817 & -- & .610 & .70847 & 4.088 & 21.0 & -4.63 & -25.20 \\
\hline & $6 / 17 / 2004$ dup & $<.2$ & 1,660 & E.1 & 2.4 & $<.04$ & -- & -- & -- & -- & -- & -- & -- & -- & -- & -- & -- \\
\hline & $9 / 20 / 2005$ & $<.2$ & 1,650 & $<.10$ & .79 & $<.04$ & -- & -- & -- & -- & -- & -- & -- & -- & -- & -- & -- \\
\hline & $7 / 14 / 2008$ & $<.1$ & 1,680 & .15 & $<1.8$ & E.01 & .327 & .036 & .030 & 1.020 & .130 & .510 & .70843 & 4.092 & 21.9 & -4.74 & -26.75 \\
\hline
\end{tabular}


Appendix 2. Relative percent difference for duplicate chemical and isotope data from wells sampled at and near an aquifer storage and recovery site, Atascosa and Wilson Counties, Texas, 2004-08.

[dup, duplicate; RPD, relative percent difference; mg/L, milligrams per liter;--, not analyzed for or not detected; <, less than; nc, not computed; $\mu \mathrm{g} / \mathrm{L}$, micrograms per liter; E, estimated; ${ }^{226} \mathrm{Ra}$, radium-226; pCi/L, picocuries per liter; ${ }^{228} \mathrm{Ra}$, radium-228; ${ }^{87 / 86} \mathrm{Sr}$, strontium-87/strontium-86; ${ }^{11 / 10} \mathrm{~B}$, boron- $11 / \mathrm{boron}-10$; $\delta^{11} \mathrm{~B}$, delta boron-11; $\delta^{18} \mathrm{O}$, delta oxygen-18; $\delta \mathrm{D}$, delta deuterium]

\begin{tabular}{|c|c|c|c|c|c|c|c|c|c|}
\hline $\begin{array}{r}\text { Well name (fig. 1): } \\
\text { U.S. Geological Survey site number: } \\
\text { State well number: }\end{array}$ & \multicolumn{3}{|c|}{$\begin{array}{c}\text { WC2 } \\
290001098250101 \\
\text { AL-68-61-810 } \\
\end{array}$} & \multicolumn{3}{|c|}{$\begin{array}{c}\text { EC1 } \\
290748098085601 \\
\text { ZL-68-55-907 } \\
\end{array}$} & \multicolumn{3}{|c|}{$\begin{array}{c}\text { WX1 } \\
291547098153501 \\
\text { ZL-68-46-902 } \\
\end{array}$} \\
\hline $\begin{array}{l}\text { Date: } \\
\text { Time: }\end{array}$ & $\begin{array}{c}9 / 19 / 2005 \\
1030\end{array}$ & $\begin{array}{c}9 / 19 / 2005 \text { dup } \\
1035\end{array}$ & RPD & $\begin{array}{l}8 / 13 / 2008 \\
1400\end{array}$ & $\begin{array}{c}8 / 13 / 2008 \text { dup } \\
1405\end{array}$ & RPD & $\begin{array}{c}6 / 17 / 2004 \\
1000\end{array}$ & $\begin{array}{c}\text { 6/17/2004 dup } \\
1010\end{array}$ & RPD \\
\hline Calcium (mg/L) & 61.4 & 61.4 & 0 & 36.1 & 36 & 0.28 & 57.7 & 57 & 1.22 \\
\hline Magnesium (mg/L) & 7.01 & 7.00 & .14 & 12.20 & 12.20 & 0 & 18.40 & 18.60 & 1.08 \\
\hline Chloride $(\mathrm{mg} / \mathrm{L})$ & 34.6 & 34.5 & .29 & 29.9 & 30 & .33 & 170 & 170 & 0 \\
\hline Fluoride (mg/L) & .39 & .39 & 0 & .41 & .41 & 0 & .73 & .73 & 0 \\
\hline Silica $(\mathrm{mg} / \mathrm{L})$ & 15.1 & 15.1 & 0 & 17.4 & 17.1 & 1.74 & 22.2 & 21.8 & 1.82 \\
\hline Sulfate (mg/L) & 35.1 & 35 & .29 & 45.5 & 45.5 & 0 & 328 & 326 & .61 \\
\hline $\begin{array}{l}\text { Residue (sum of constituents) } \\
\text { (mg/L) }\end{array}$ & 296 & 284 & 4.14 & 394 & 392 & .51 & 1,040 & 1,080 & 3.77 \\
\hline Dissolved nitrite nitrogen $(\mathrm{mg} / \mathrm{L})$ & -- & -- & -- & -- & -- & -- & $<.008$ & $<.008$ & nc \\
\hline $\begin{array}{l}\text { Dissolved orthophosphate } \\
\text { phosphorus (mg/L) }\end{array}$ & -- & -- & -- & -- & -- & -- & $<.02$ & $<.02$ & nc \\
\hline Dissolved phosphorus (mg/L) & -- & -- & -- & -- & -- & -- & $<.04$ & $<.04$ & nc \\
\hline Aluminum $(\mu \mathrm{g} / \mathrm{L})$ & $<1.6$ & 2.4 & nc & $<1.6$ & $<1.6$ & $\mathrm{nc}$ & $<1.6$ & $<1.6$ & nc \\
\hline Antimony $(\mu \mathrm{g} / \mathrm{L})$ & $<.20$ & $<.20$ & $\mathrm{nc}$ & $<.14$ & $<.14$ & $\mathrm{nc}$ & $<.20$ & $<.20$ & $\mathrm{nc}$ \\
\hline Arsenic $(\mu \mathrm{g} / \mathrm{L})$ & $<.12$ & $<.12$ & $\mathrm{nc}$ & $<.06$ & $<.06$ & $\mathrm{nc}$ & E.2 & E.2 & $\mathrm{nc}$ \\
\hline Barium $(\mu \mathrm{g} / \mathrm{L})$ & 116 & 117 & .86 & 119 & 119 & 0 & 17 & 17 & 0 \\
\hline Beryllium $(\mu \mathrm{g} / \mathrm{L})$ & $<.06$ & $<.06$ & $\mathrm{nc}$ & .01 & .01 & 0 & $<.06$ & $<.06$ & $\mathrm{nc}$ \\
\hline Boron $(\mu \mathrm{g} / \mathrm{L})$ & 134 & 133 & .75 & 130 & 128 & 1.55 & 405 & 410 & 1.23 \\
\hline Lithium $(\mu \mathrm{g} / \mathrm{L})$ & 16.9 & 17.1 & 1.18 & 36.6 & 36.7 & .27 & 124 & 124 & 0 \\
\hline Dissolved manganese $(\mu \mathrm{g} / \mathrm{L})$ & 68.3 & 78.8 & 14.3 & 12.7 & 12.4 & 2.39 & 24.7 & 24.7 & 0 \\
\hline Total manganese $(\mu \mathrm{g} / \mathrm{L})$ & 74.8 & 77.1 & 3.03 & 14.2 & 14.1 & .71 & 29.3 & 28.6 & 2.42 \\
\hline Molybdenum $(\mu \mathrm{g} / \mathrm{L})$ & 1.2 & 1.2 & 0 & $<.2$ & $<.2$ & nc & 1.7 & 1.7 & 0 \\
\hline Nickel $(\mu \mathrm{g} / \mathrm{L})$ & $<.06$ & 2.1 & $\mathrm{nc}$ & .28 & .23 & 19.6 & .37 & .36 & 2.74 \\
\hline Selenium $(\mu \mathrm{g} / \mathrm{L})$ & $<.08$ & $<.08$ & $\mathrm{nc}$ & $<.04$ & $<.04$ & nc & .6 & .7 & 15.4 \\
\hline Silver $(\mu \mathrm{g} / \mathrm{L})$ & $<.2$ & $<.2$ & $\mathrm{nc}$ & $<.1$ & $<.1$ & $\mathrm{nc}$ & $<.2$ & $<.2$ & $\mathrm{nc}$ \\
\hline Strontium $(\mu \mathrm{g} / \mathrm{L})$ & 369 & 372 & .81 & 941 & 929 & 1.28 & 1,660 & 1,660 & 0 \\
\hline Vanadium $(\mu \mathrm{g} / \mathrm{L})$ & $<.10$ & $<.10$ & $\mathrm{nc}$ & E.04 & E.04 & $\mathrm{nc}$ & .1 & E. 1 & $\mathrm{nc}$ \\
\hline $\operatorname{Zinc}(\mu \mathrm{g} / \mathrm{L})$ & .74 & .6 & 20.9 & $<1.8$ & $<1.8$ & $\mathrm{nc}$ & 2.4 & 2.4 & 0 \\
\hline Uranium $(\mu \mathrm{g} / \mathrm{L})$ & $<.04$ & $<.04$ & $\mathrm{nc}$ & $<.02$ & $<.02$ & $\mathrm{nc}$ & $<.04$ & $<.04$ & $\mathrm{nc}$ \\
\hline${ }^{226} \mathrm{Ra}(\mathrm{pCi} / \mathrm{L})$ & -- & -- & -- & .557 & .566 & 1.60 & .201 & -- & -- \\
\hline${ }^{228} \mathrm{Ra}(\mathrm{pCi} / \mathrm{L})$ & -- & -- & -- & 1.920 & 1.690 & 12.7 & .817 & -- & -- \\
\hline${ }^{87 / 86} \mathrm{Sr}$ & -- & -- & -- & .708 & .708 & .003 & .708 & -- & -- \\
\hline${ }^{11 / 10} \mathrm{~B}$ & -- & -- & -- & 4.110 & 4.126 & .39 & 4.088 & -- & -- \\
\hline$\delta^{11} \mathrm{~B}$ (per mil) & -- & -- & -- & 26.5 & 30.5 & 14.0 & 20.98 & -- & -- \\
\hline$\delta^{18} \mathrm{O}($ per mil $)$ & -- & -- & -- & -4.57 & -4.65 & 1.74 & -4.63 & -- & -- \\
\hline$\delta \mathrm{D}$ (per mil) & -- & -- & -- & -26.90 & -25.68 & 4.64 & -25.20 & -- & -- \\
\hline
\end{tabular}




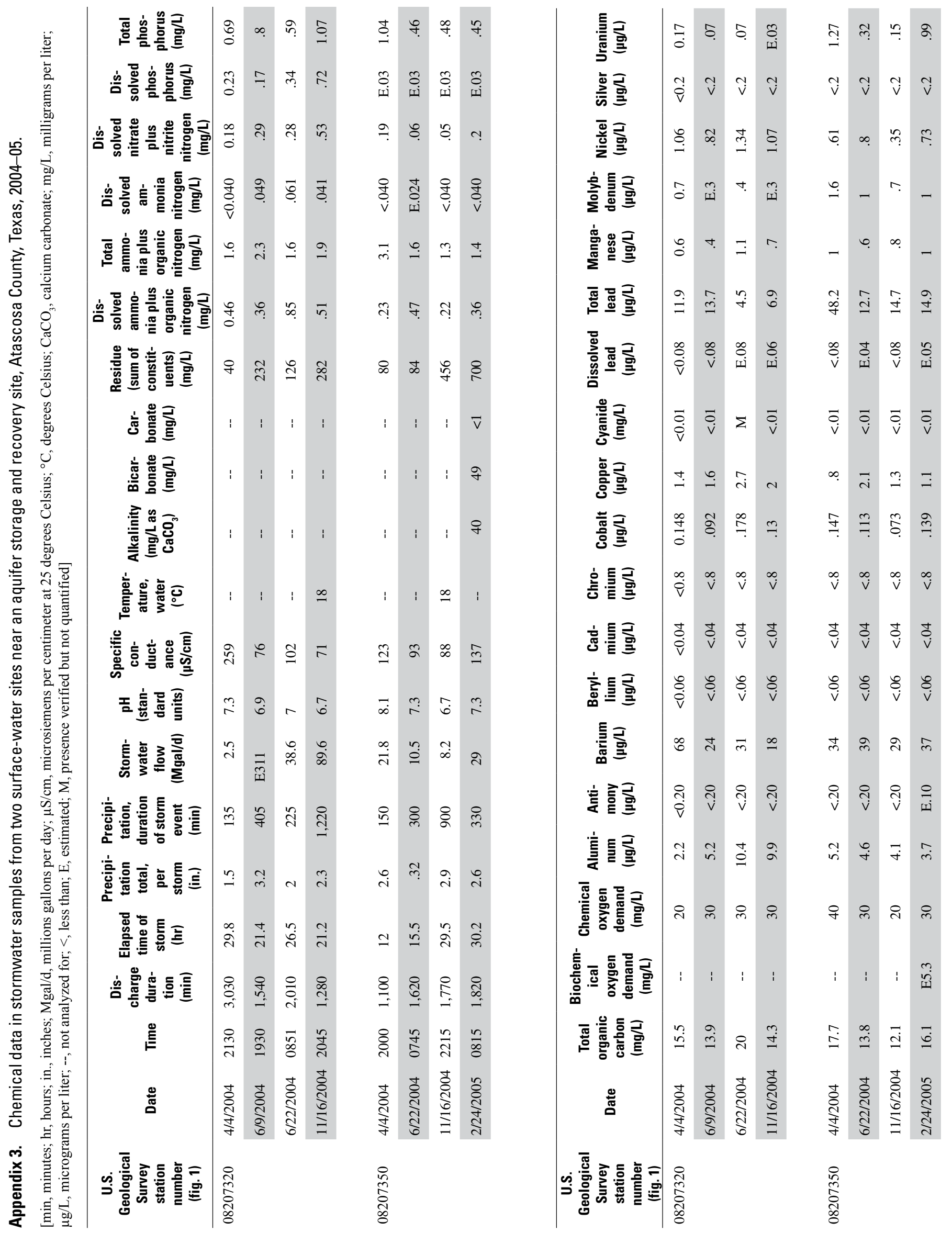




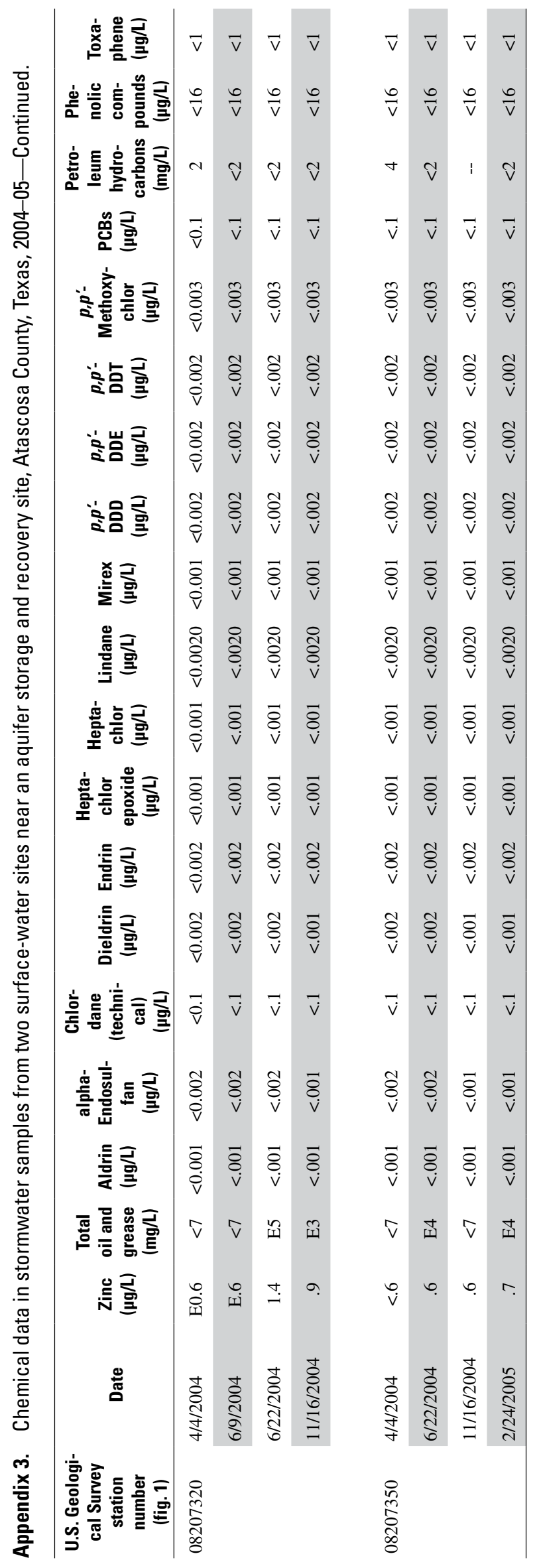


Appendix 4. Bacteria data in stormwater samples from two surface-water sites near an aquifer storage and recovery site, Atascosa County, Texas, 2004-05.

[cols./100 mL, colonies per 100 milliliters; --, not analyzed; E, estimated from non-ideal colony count]

\begin{tabular}{ccccc}
\hline $\begin{array}{c}\text { U.S. Geological Survey } \\
\text { station number } \\
\text { (fig. 1) }\end{array}$ & Date & Time & $\begin{array}{c}\text { Escherichia coli } \\
\text { (cols./100 mL) }\end{array}$ & $\begin{array}{c}\text { Fecal streptococci } \\
\text { (cols./100 mL) }\end{array}$ \\
\hline 08207320 & $4 / 4 / 2004$ & 2100 & 480,000 \\
& $6 / 9 / 2004$ & 2010 & 22,000 \\
& $6 / 22 / 2004$ & 1220 & E6,000 \\
& $11 / 16 / 2004$ & 2145 & 78,000 & -- \\
\hline 08207350 & & & 24,000 \\
& $4 / 4 / 2004$ & 1930 & E23,000 \\
& $6 / 22 / 2004$ & 1200 & 49,000 \\
\hline
\end{tabular}

Publishing support provided by Lafayette Publishing Service Center

Information regarding water resources in Texas is available at http://tx.usgs.gov/ 
Blank Page 


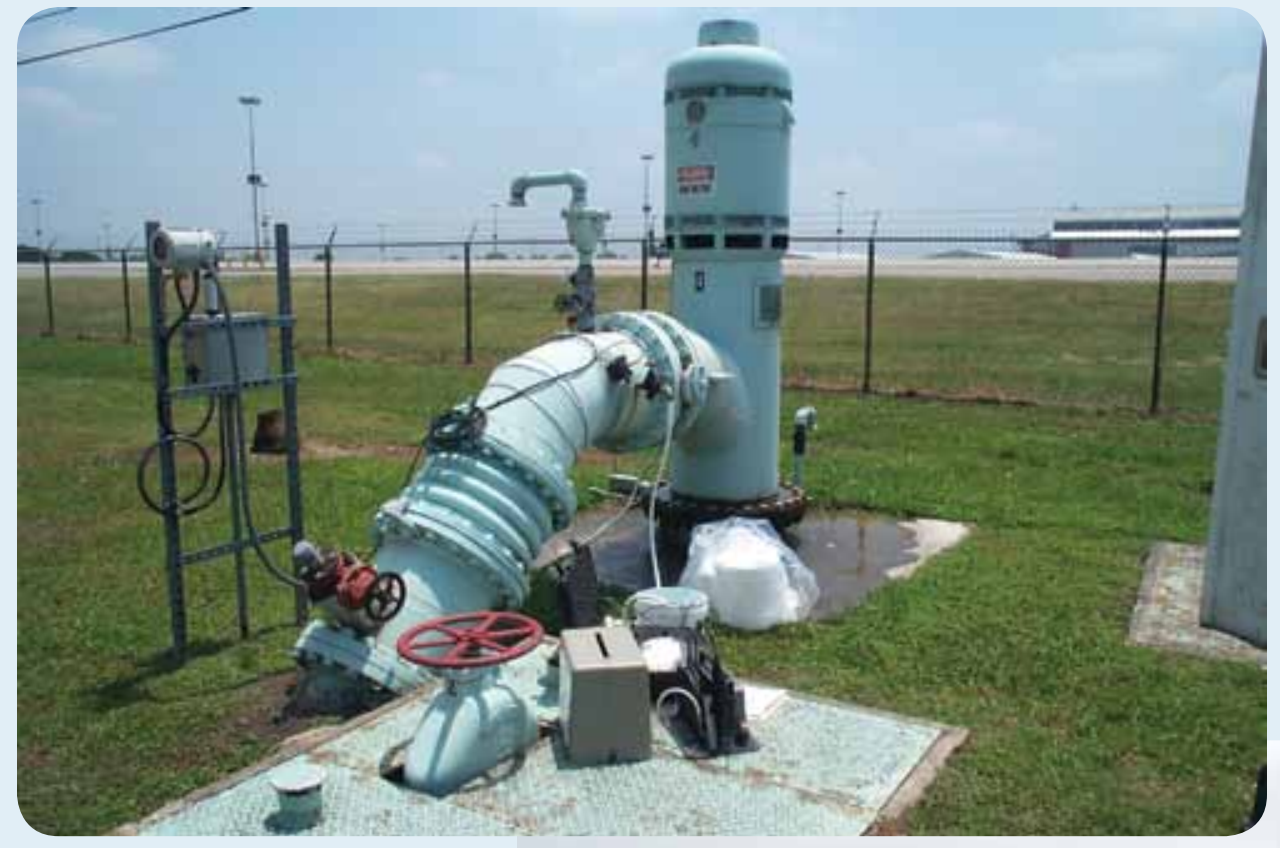

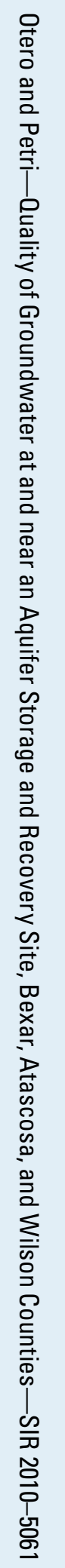

